\title{
CORRELATION OF ACCIDENT \\ RATES AND ROADWAY FACTORS
}

JULY, 1957

NO. 27 
: . . + + 
Plnal Reporte

CORRELATION OF ACCIDENT RATES AND

ROADWAY FACTORS

TO8 I. B. Woods Diregtor

Joint HIghwry Rosearch Projoct

Iำ 24,1957

FROM: Ho I. Kichaed, Assigtant Direstor

Pile: $8-5-3$

Project No, C-36-59C

Atteched is a Ploal report eat1tled "Coxrelation of Accident Rates and Roadway Pactors ${ }_{2}$ by John C. $\mathrm{H}_{0}$ Woo, Graduate Asvietant on our stafl. This report has also been used by Mr. Woo as his thesls in partial fulfillment of the requimements for the degree of Haster of Selence. The study was approved by the Board on January 248 2957 and was performed under the directlon of Professor H, L, MLhael.

The results of the statistical anslysis of the corralation of accidents with eertain rosdway factors on the State Rural Prinary System in Indiana indicato that there is a corrolation of traffice volume $e_{8}$ congestion index, number of entrances per mile and lane widh with number of accidents per mile.

As another product of thris atudy a listing of the high aceident locatsons on the State Prinary System is boing propared and will 2180 be subarifted to the Board as information:

Th10 report is presented for the record?

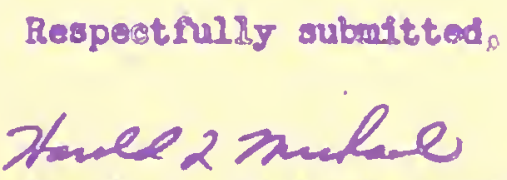

Harold Lo Michael Asiatant Direotor Joint Highway Research Project

HLK: hgb

Attachent

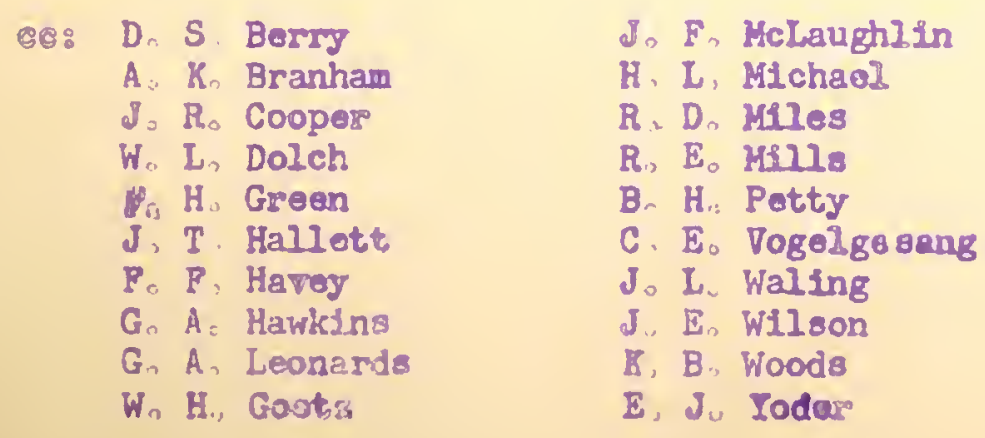


Digitized by the Internet Archive in 2011 with funding from

LYRASIS members and Sloan Foundation; Indiana Department of Transportation 
Plnal Report

CORRELATION OF ACCIDENT RATES AND

ROADWAY FACTORS

by

dohn C.H. Wo

Greduat Assistant

Bolnt HLimay Research Projects

Project No, $\mathrm{C} \rightarrow 36 \Rightarrow 59 \mathrm{C}$

FI? $\quad<5=3$

Purdue University

Lafayetto, Indisana

July 24,1957 


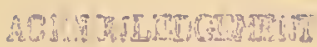

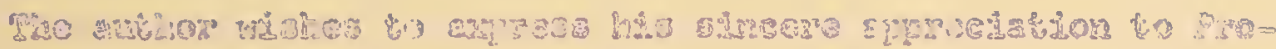
यE.

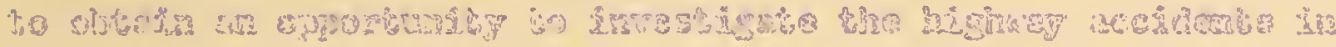
Lho

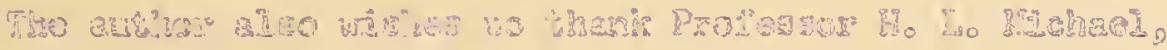

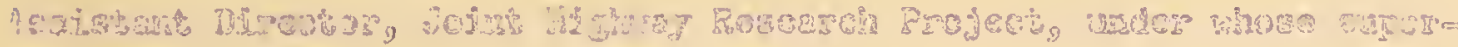

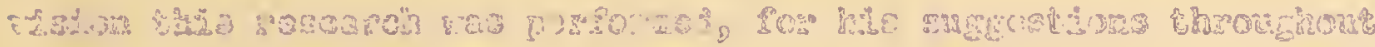

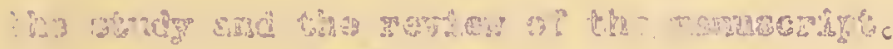

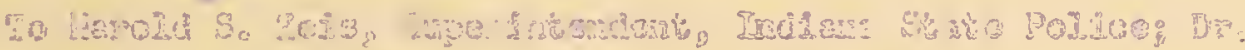

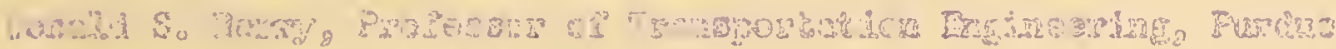

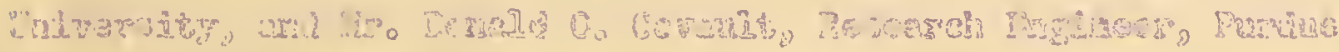

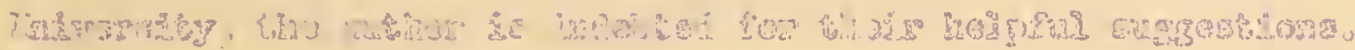

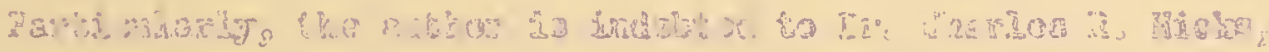

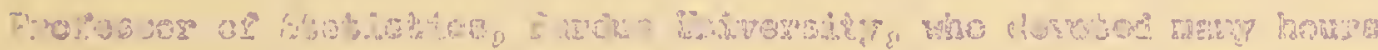

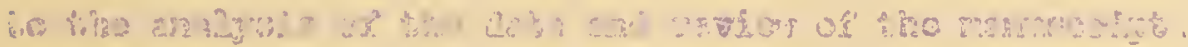

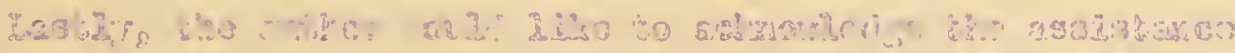

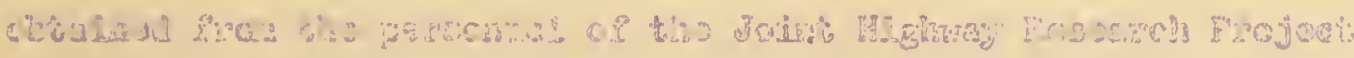

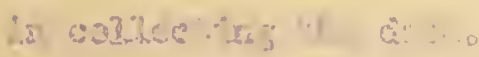




\section{MAPE OF COHTES}

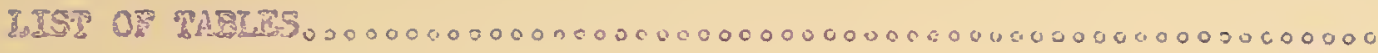
38

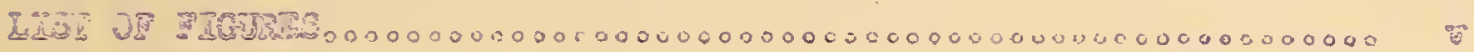

AESTMACT 000000000000000000000000000000000000006000000000000000000 ซึ?

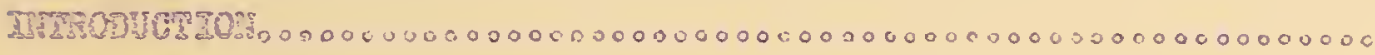
PWT3005T00000000000000000000000000000000000000000000000000000000000

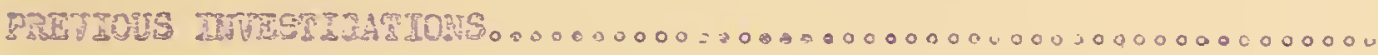
FEOPTEIRE 000000000000000000000000000000000000000000000000000000000

Ced?

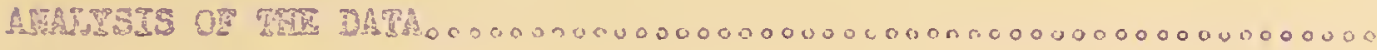

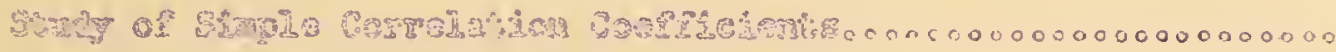

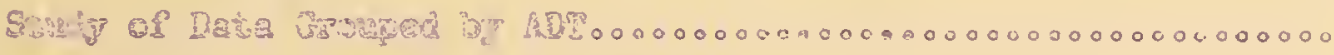

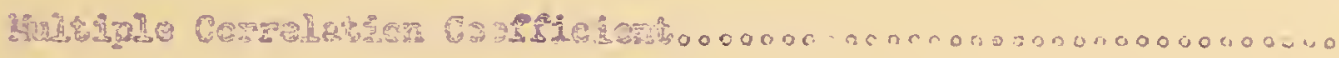

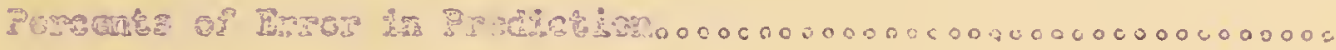

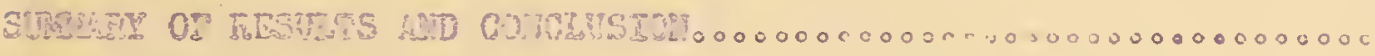

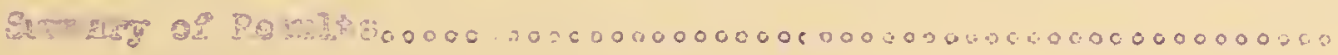

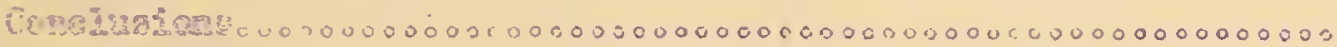
2 3.2ERCt

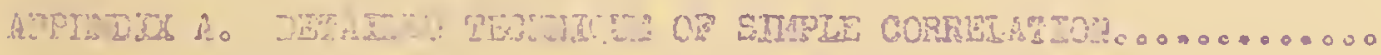
5

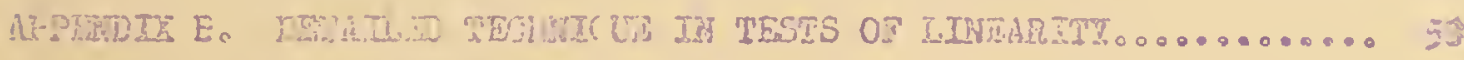

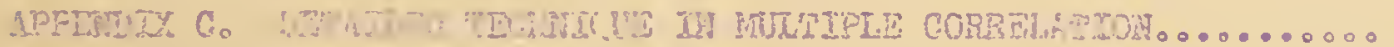


DQTS OP TALES

Teme

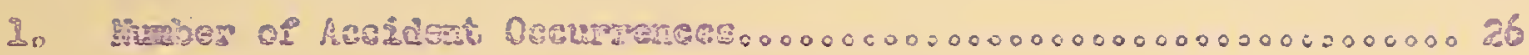

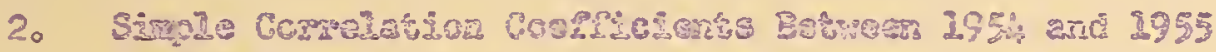

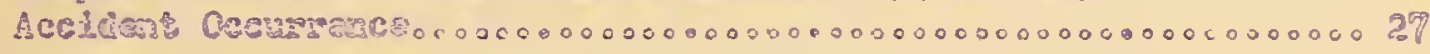

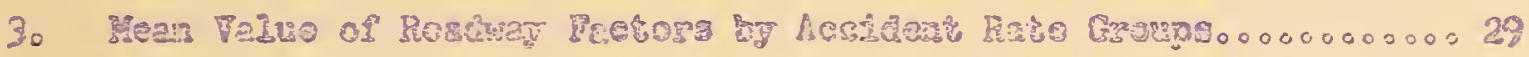

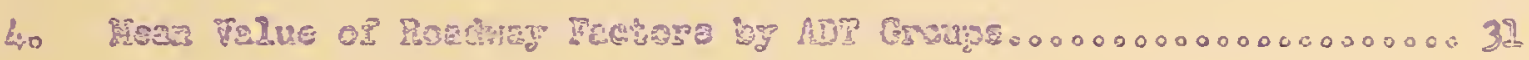

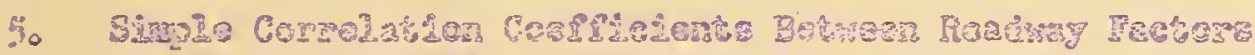

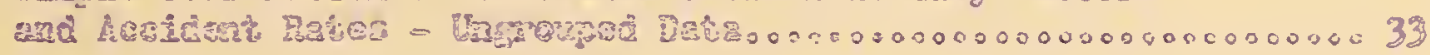

6. Sมำ

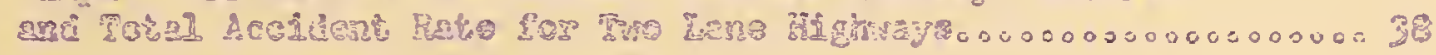

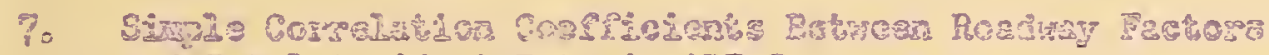

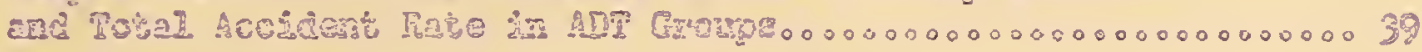

E. גొน

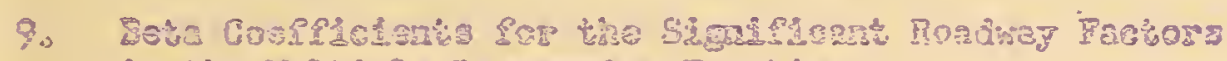

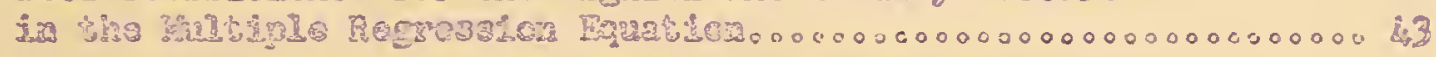

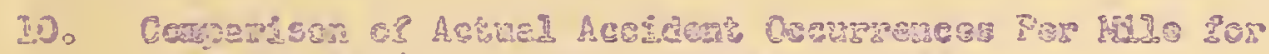

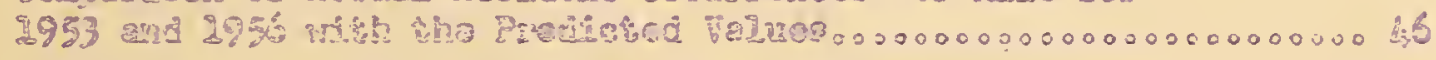

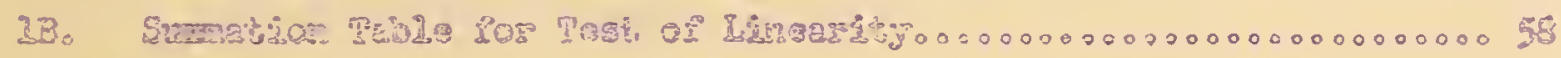

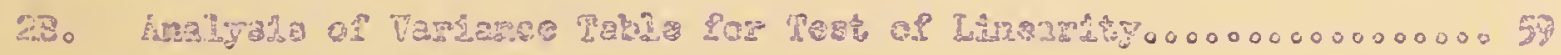

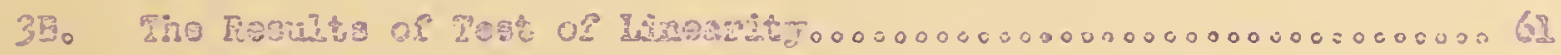

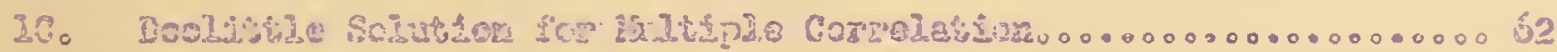




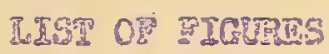

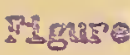

$\operatorname{Pags}$

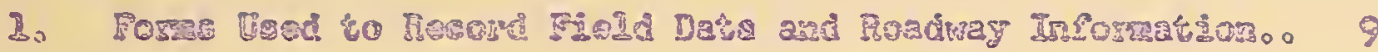

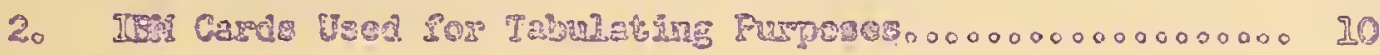

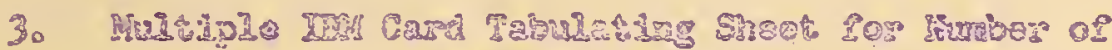

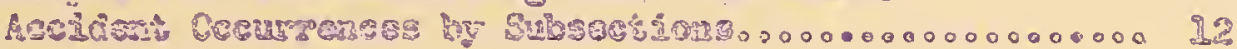

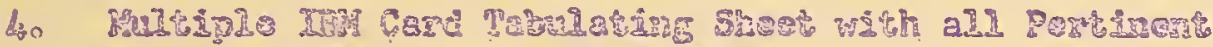

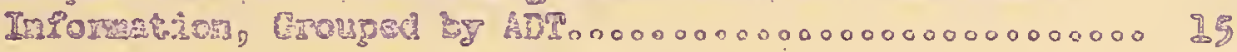

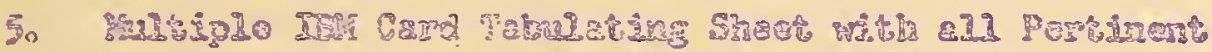

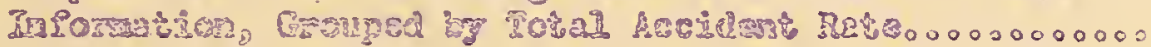

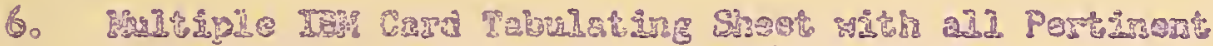
TH

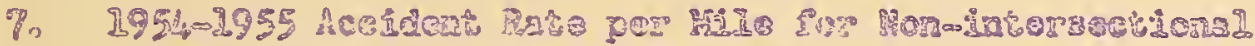

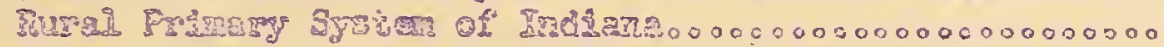

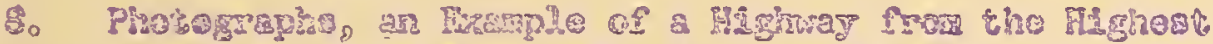

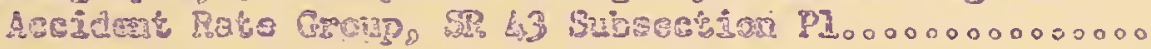

9. Enotoms 尔3

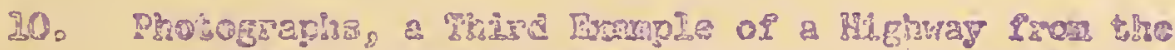

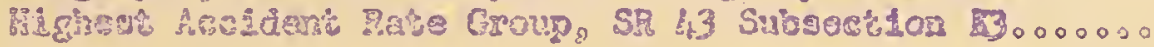

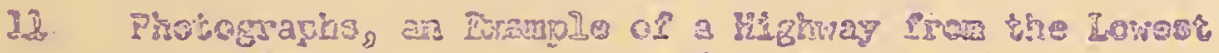

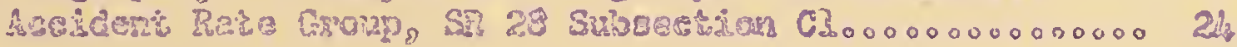

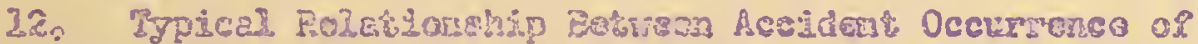

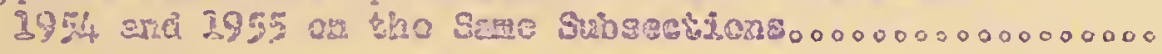

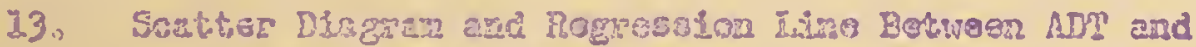

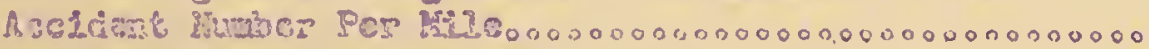

$\therefore$ : Scaitor DLagrn and Regterion Inrs Boturean Congestion

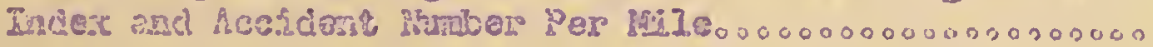




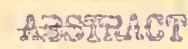

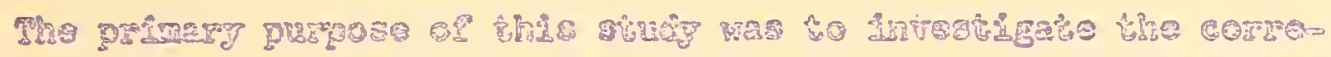

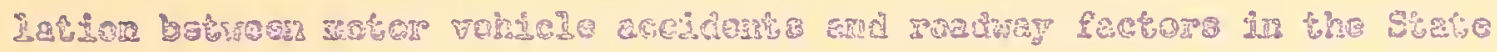

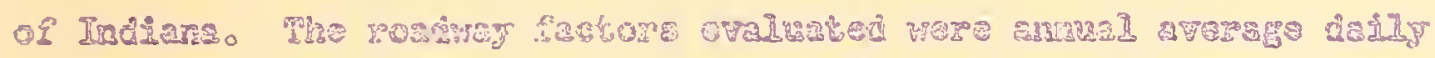

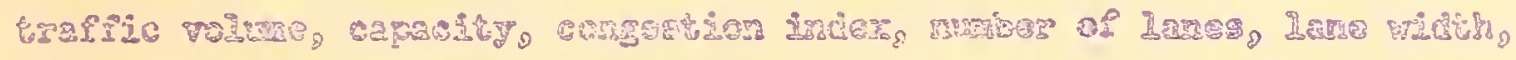

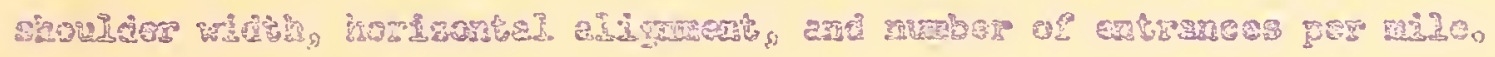
F⿸尸广

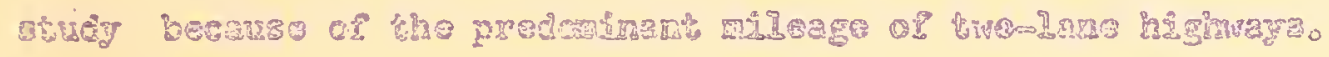

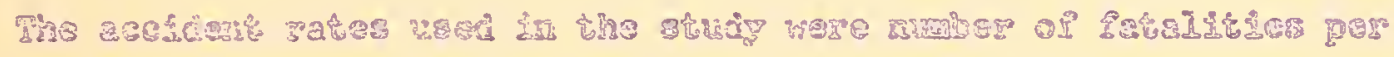

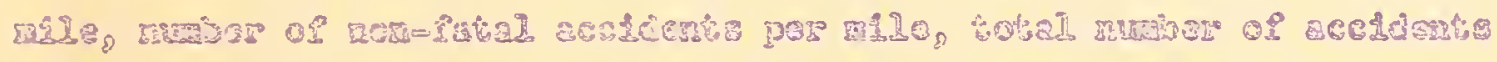
per 2180 an

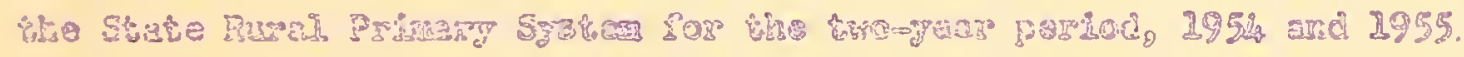

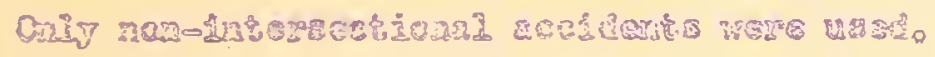

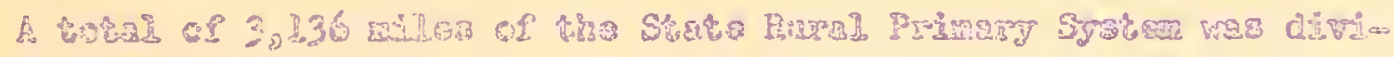

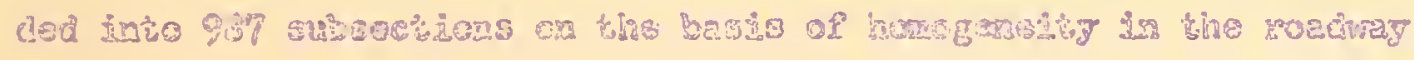
LEG

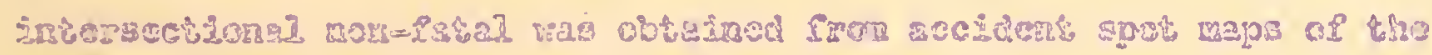

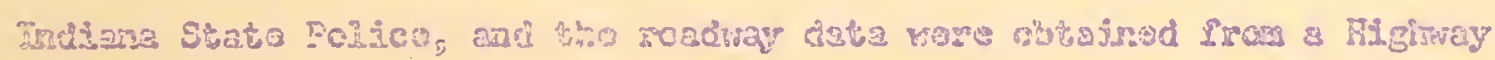

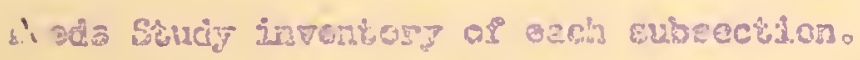

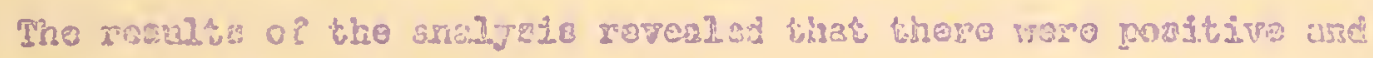

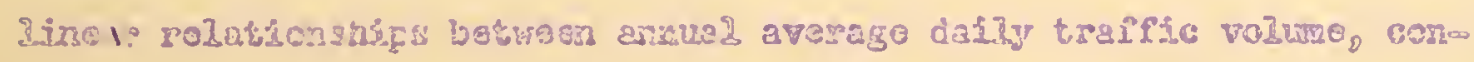

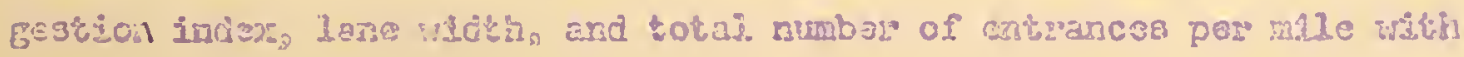




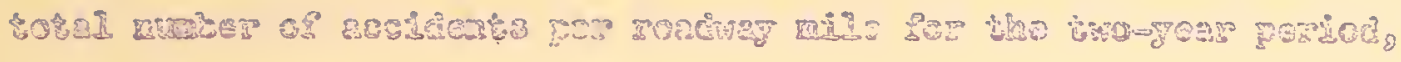

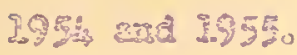

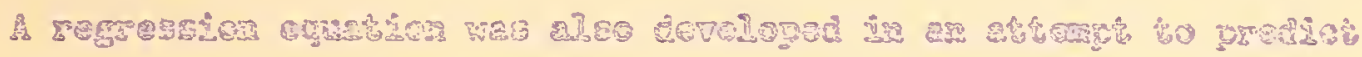

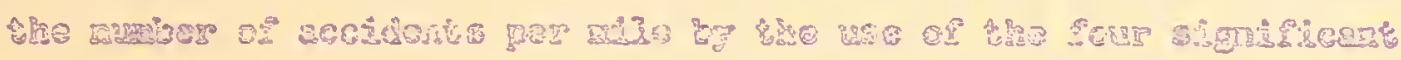

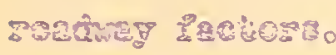


CORRELATION OF ACCIDINT RATES ARD ROADIKY FACTORS

\section{INITODUCTIOA}

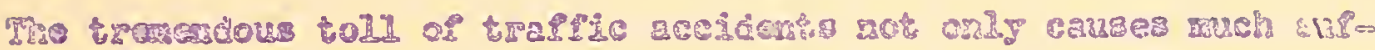

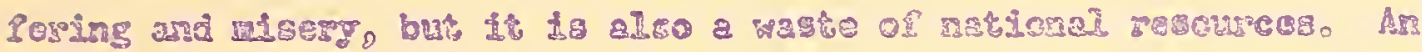

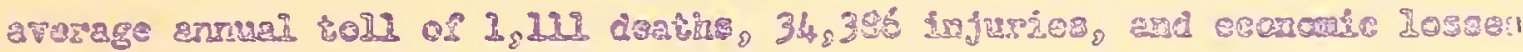

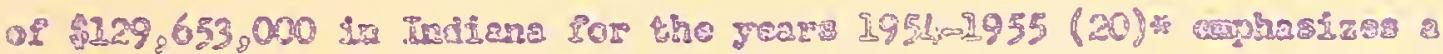

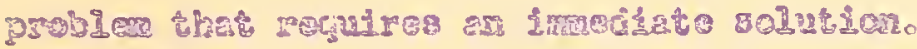

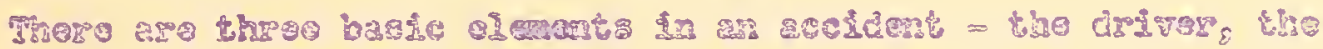

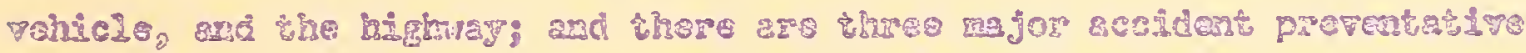

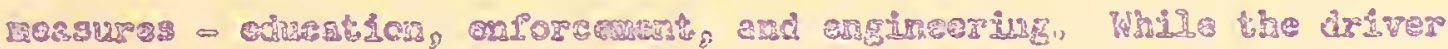

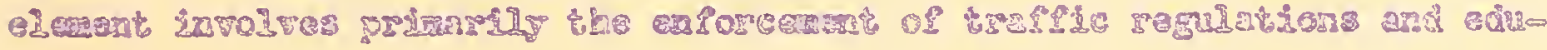

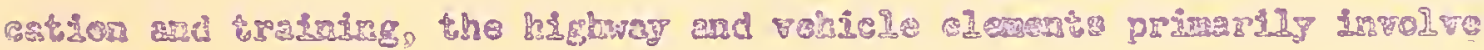
ençaceriag?

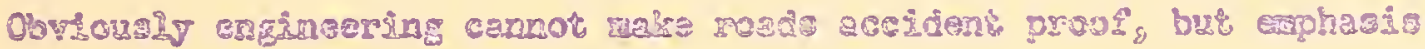

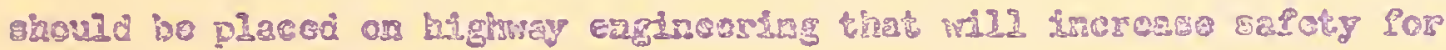

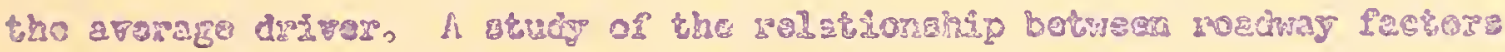

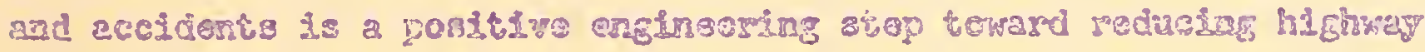

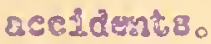

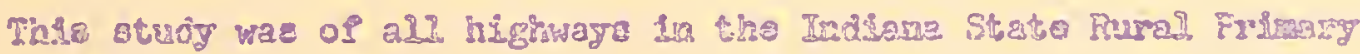

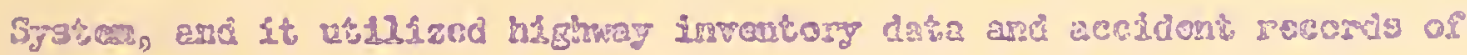

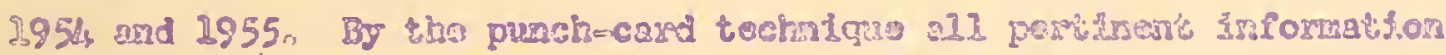

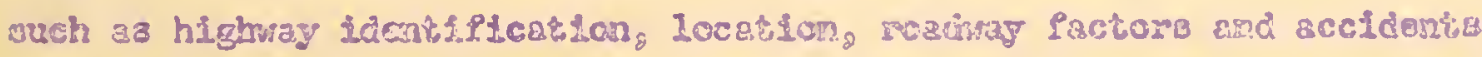

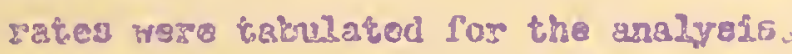




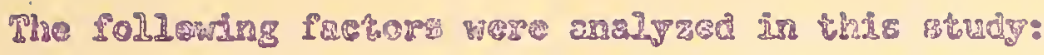

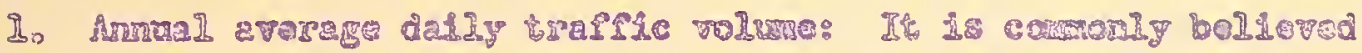

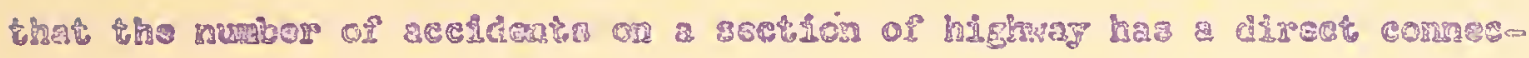

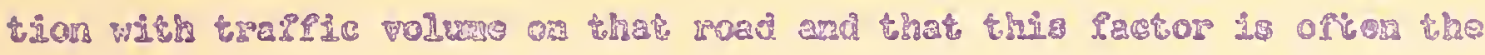

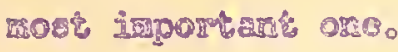

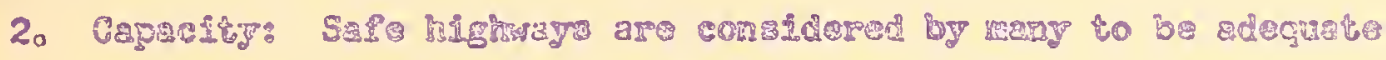

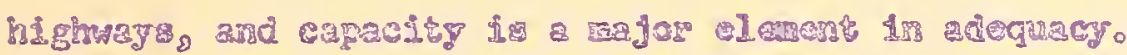

3. Conge

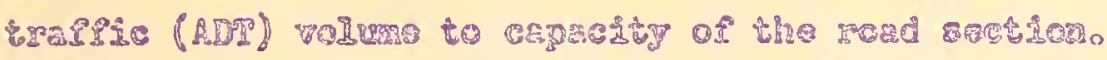

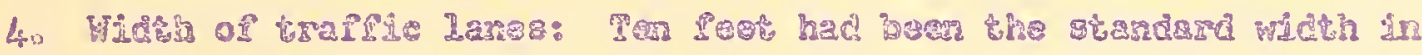

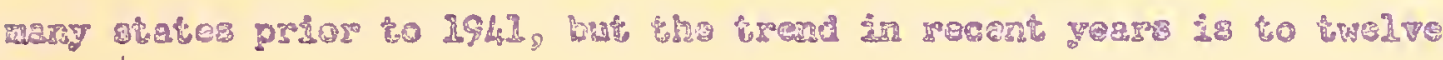
Pese or mor B. $^{2}$

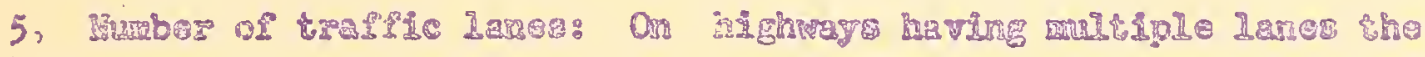

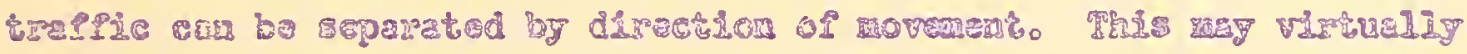
elininate ors of the mars ty

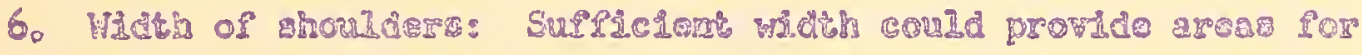

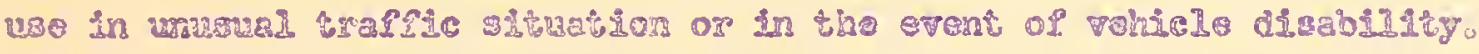

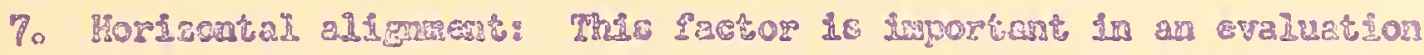

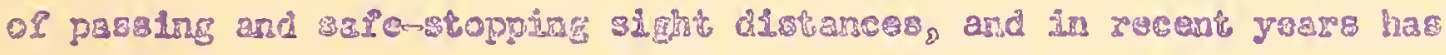

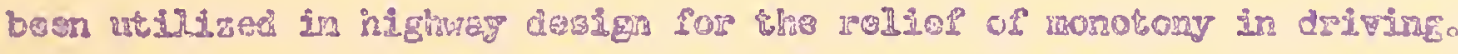

8. Number of ankfanco polnts: An increebing aumber of accoss pointo

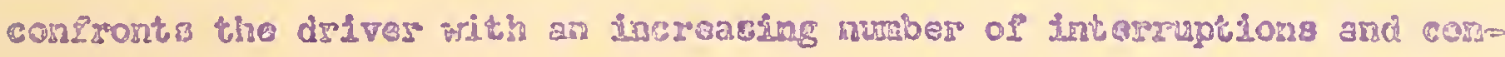
Micte,

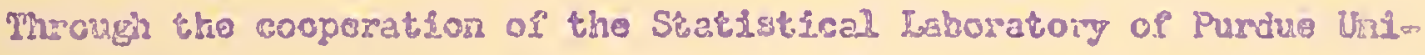

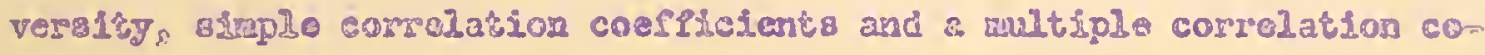
epftctent were calculated in orjer to doternine tho rolationship bstwesn 


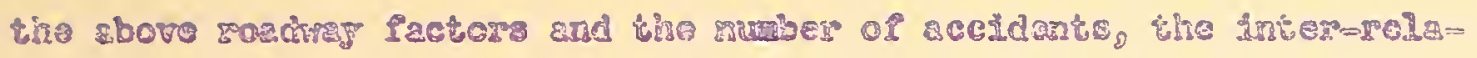

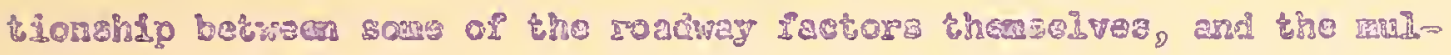

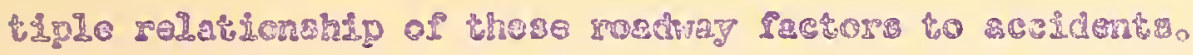




\section{PURPOS}

Th้ prypose of this

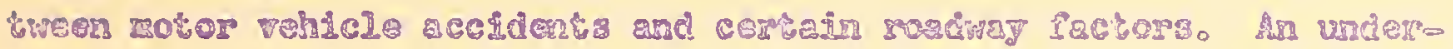

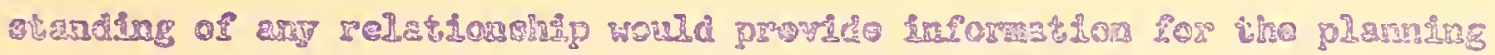

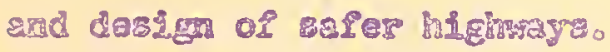

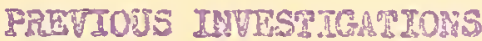

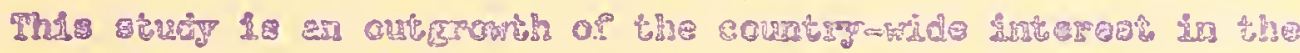

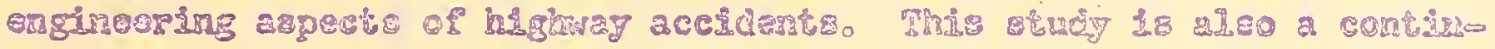

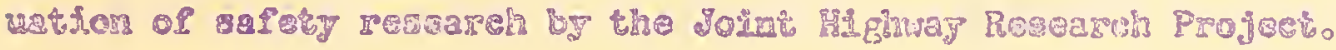

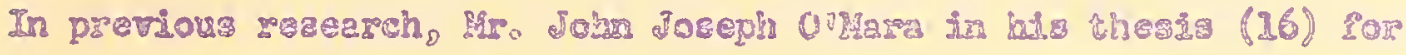

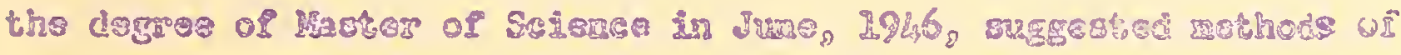

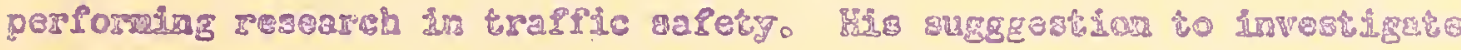

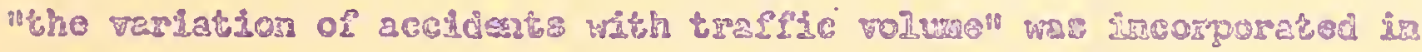
tris studg?

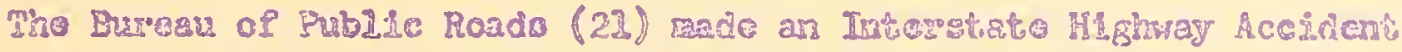

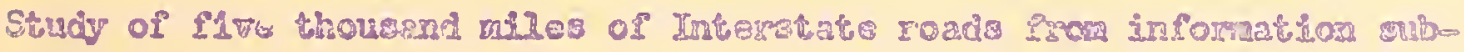

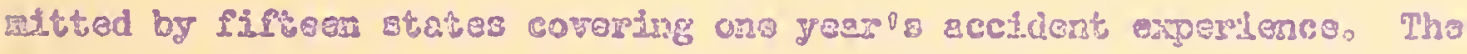

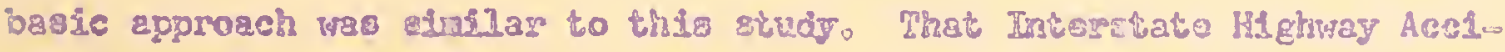
dent stuot found that traffic voltur had a tirong affect on accidert

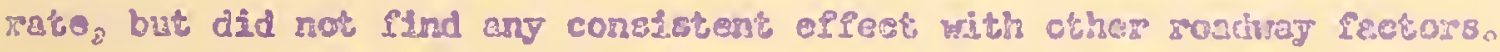

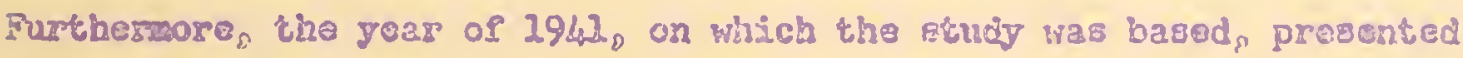
extiroly different dxitheng conditions from what we have nown

Mang states alco have been ective in trylng to flud scre dofinlto 


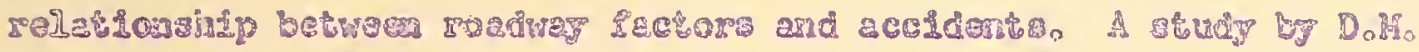

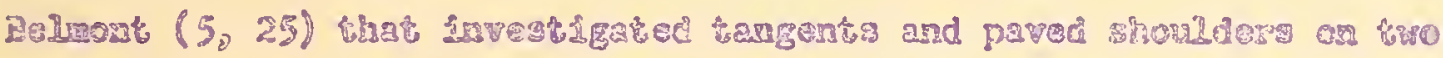

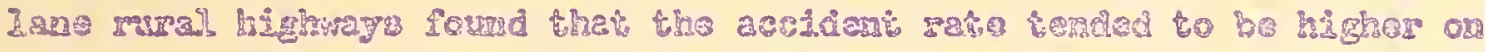

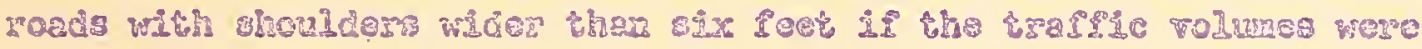
ำำำㄴำ

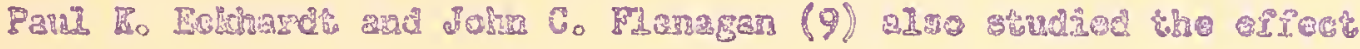

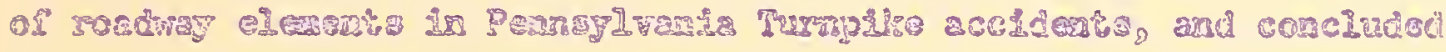

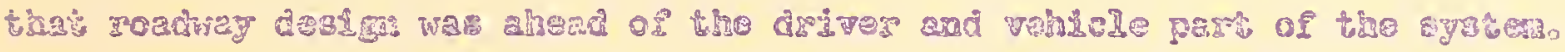

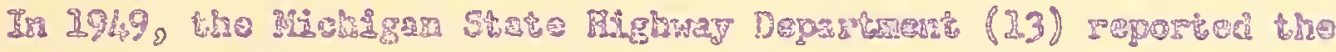

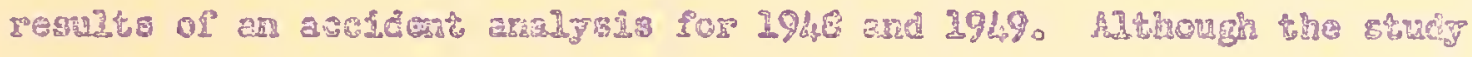
Exphaว to 5e dir

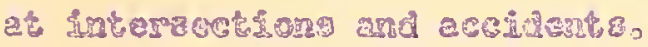

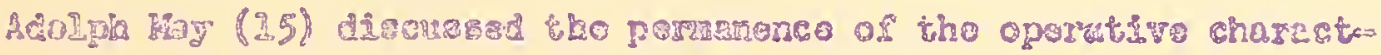

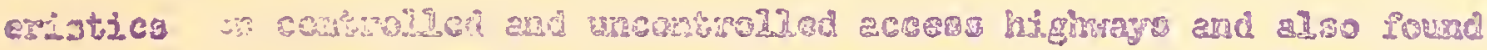

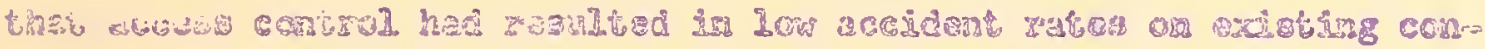

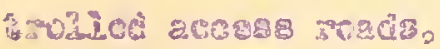

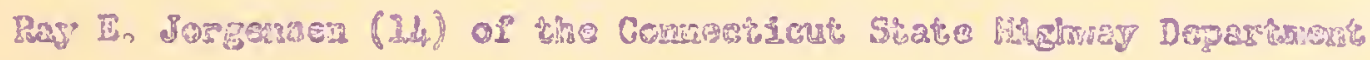

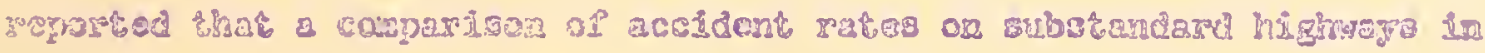
dis?

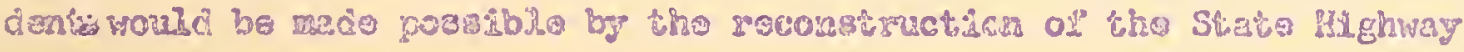

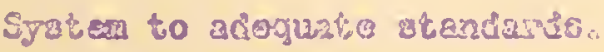

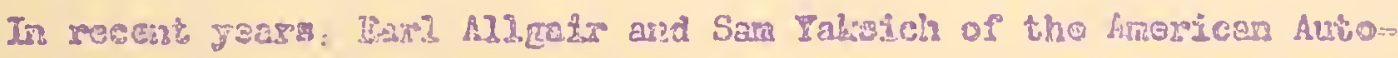

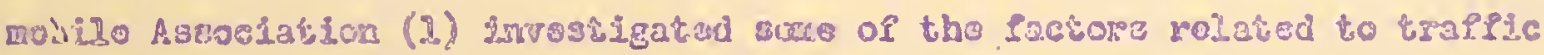

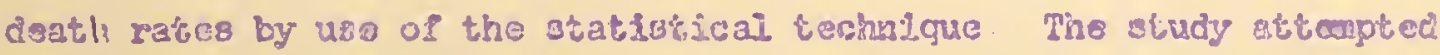
to deloming the charectoriatres of the variove states which ware related 


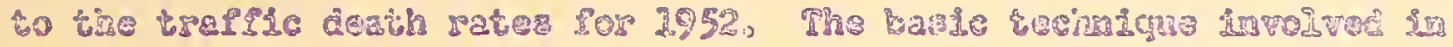

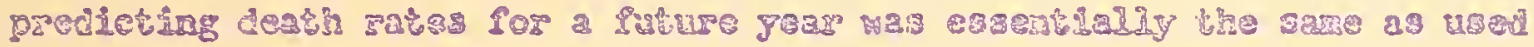
Lis ting roseaste.

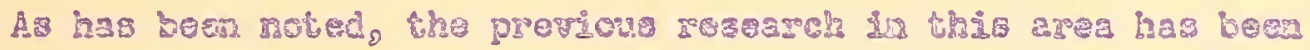

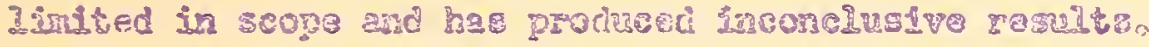




\section{EOCEEDUF露}

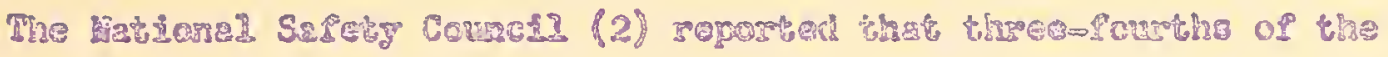

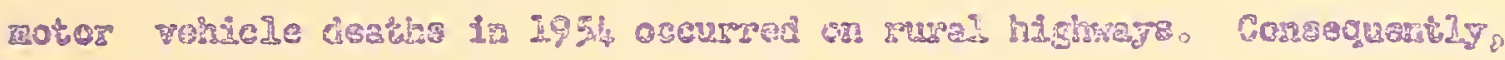

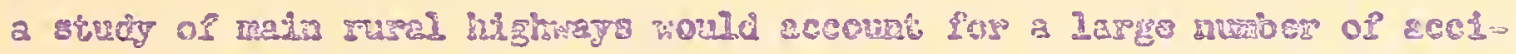
dests in the state.

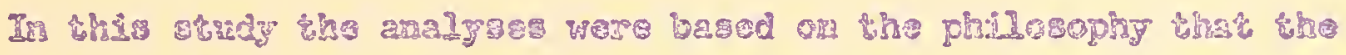

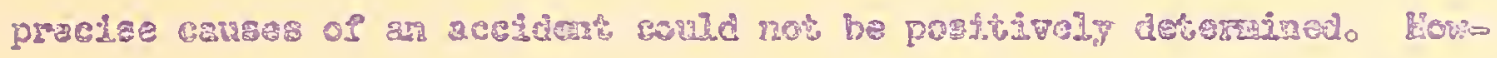

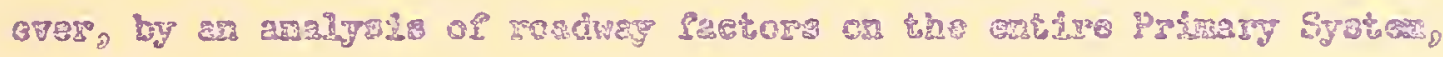

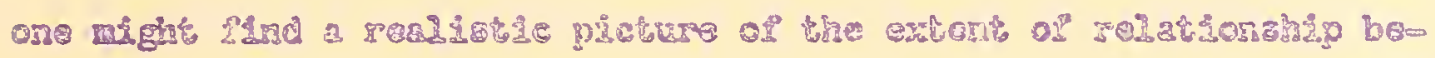

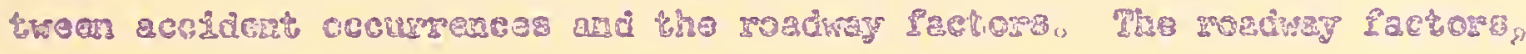

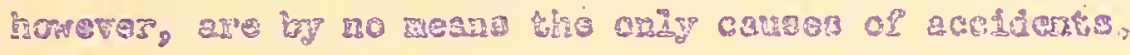

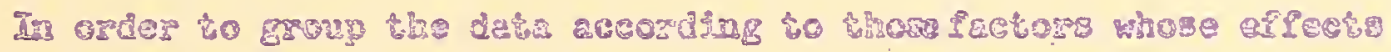

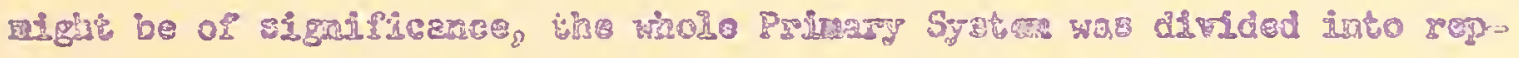

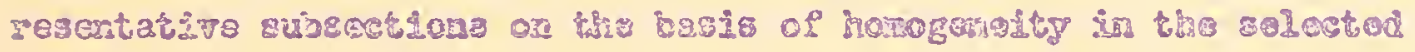

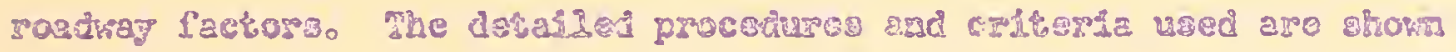
Lia the followisg page.

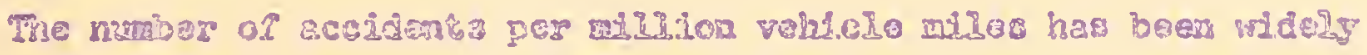

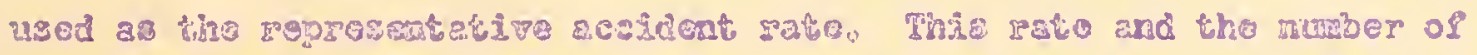

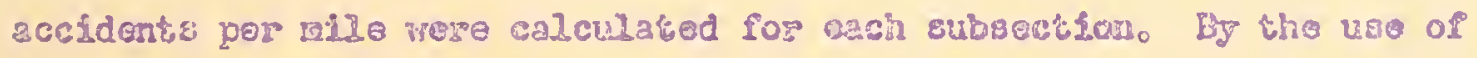
the above two rater, it wes hoped to fird the betrer corralarso accident sate.

\section{Colyection of Defs}

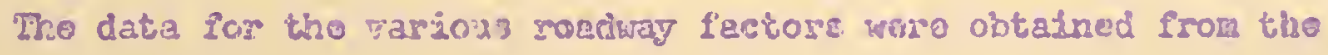




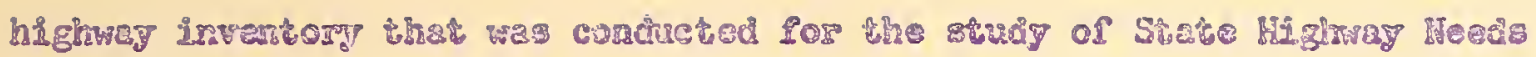

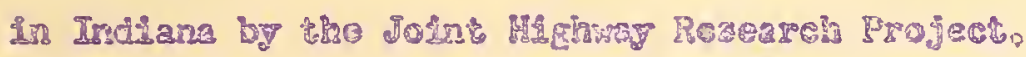

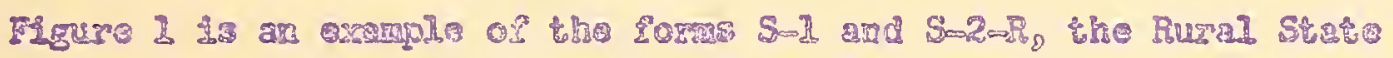

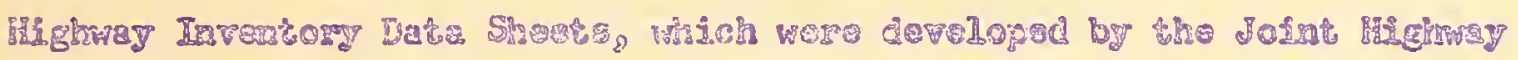

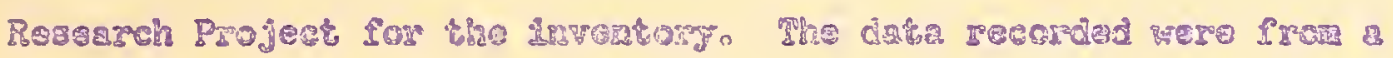

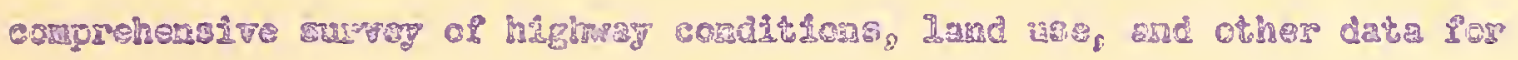

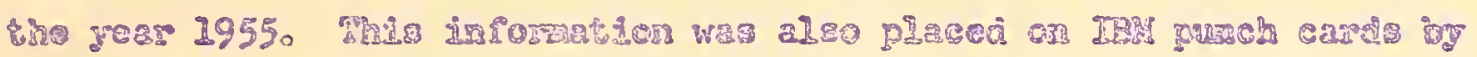

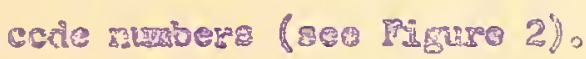

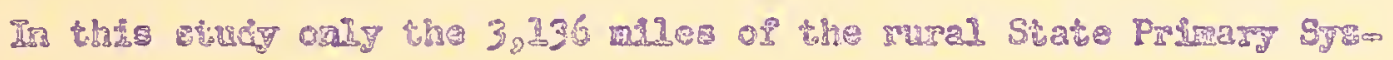

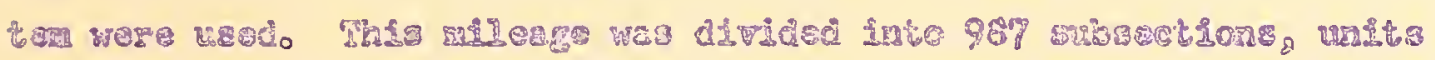

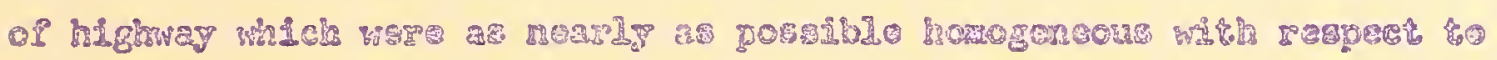

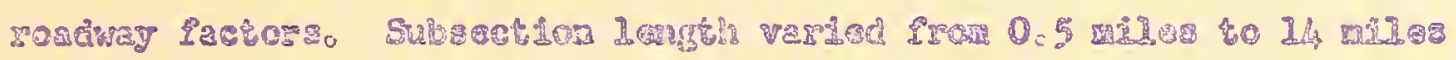

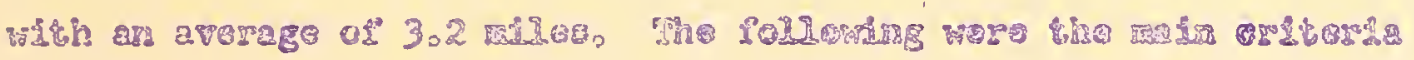

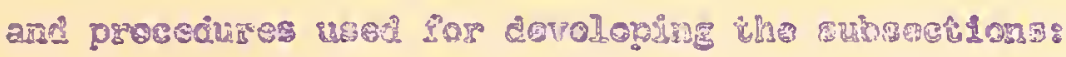

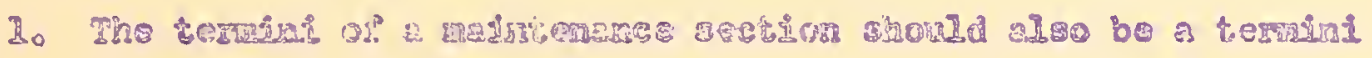

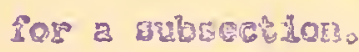

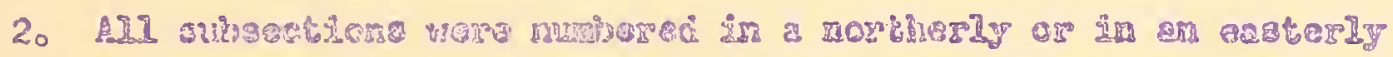

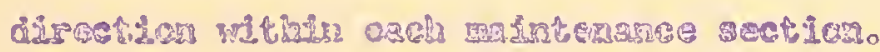

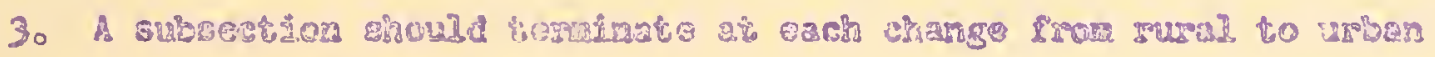

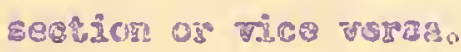

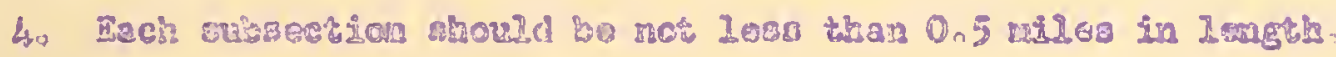

5. A subscriton sheuld pozalnate ot eqch change frow divided to

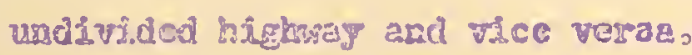

6. A 8ubvestion ehculd terninate at sach chango of $10 \%$ or noro in traficic rolues,

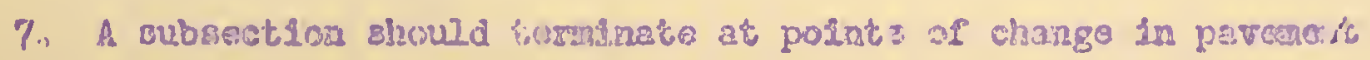




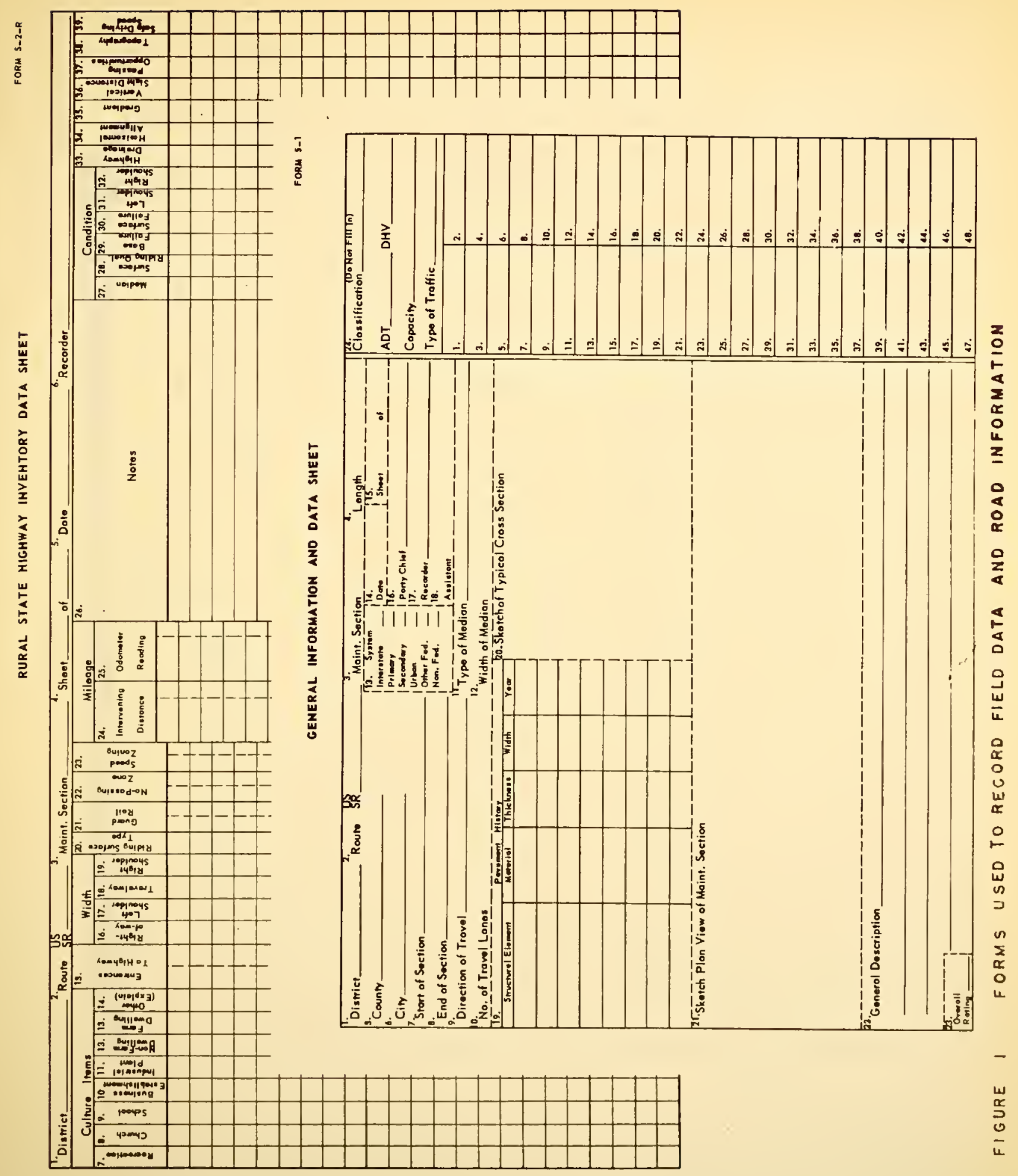



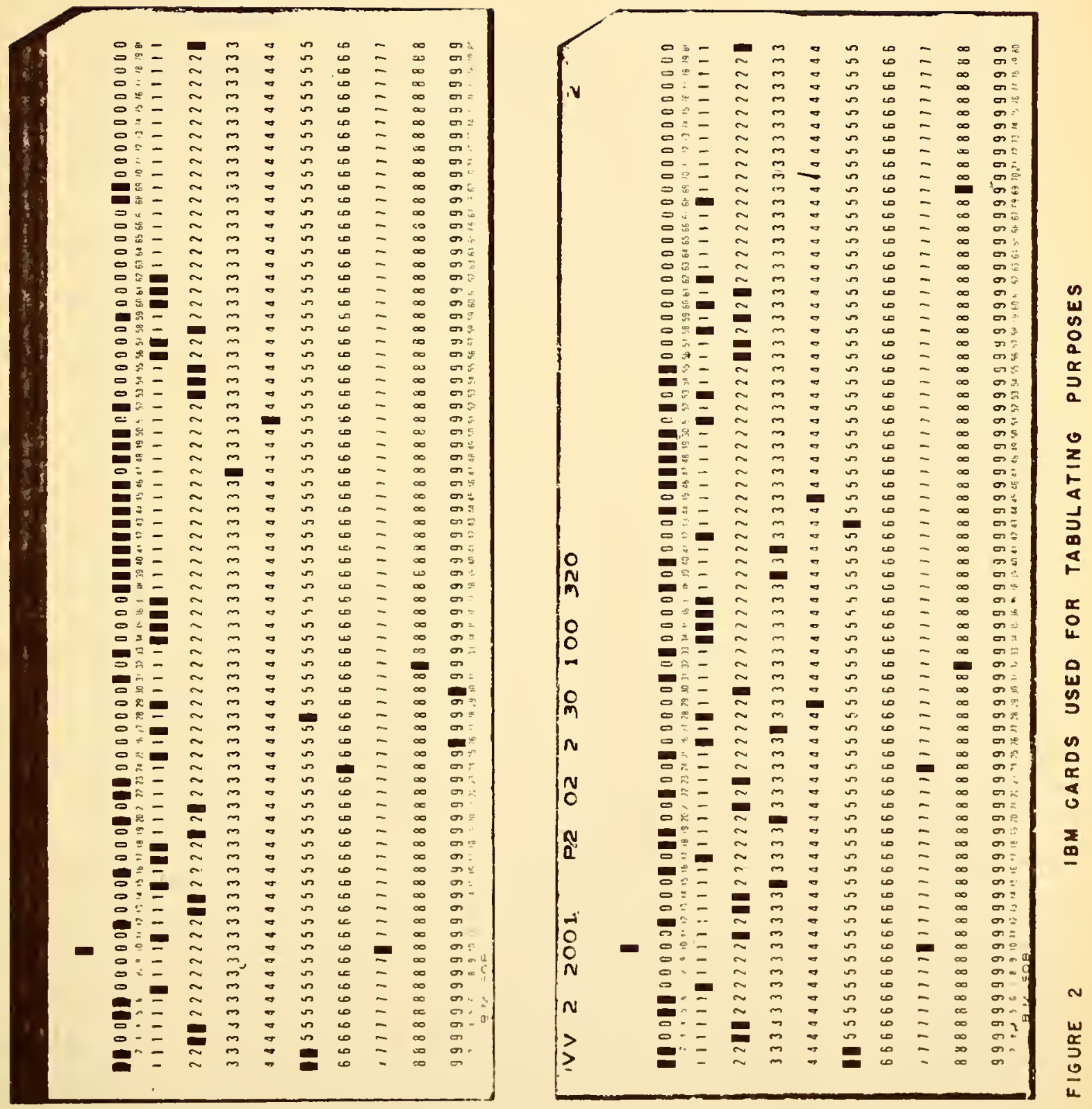
พxdใน

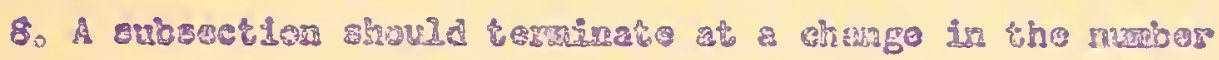

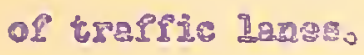

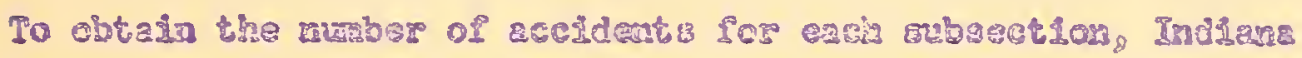

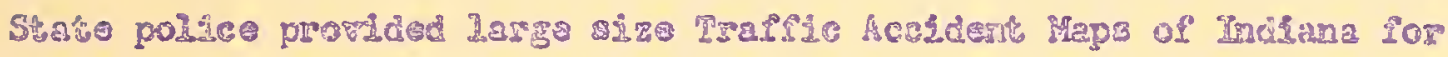

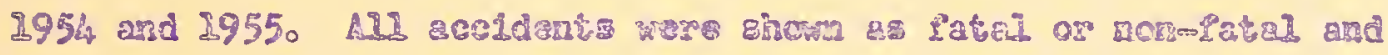

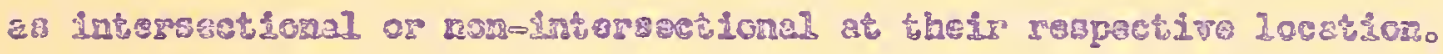

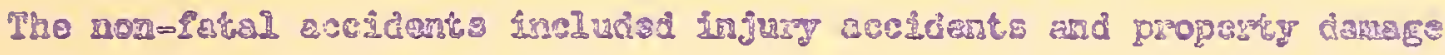

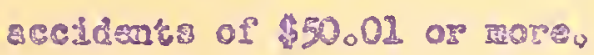

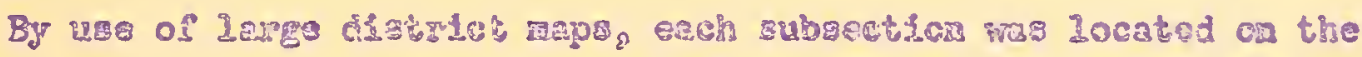

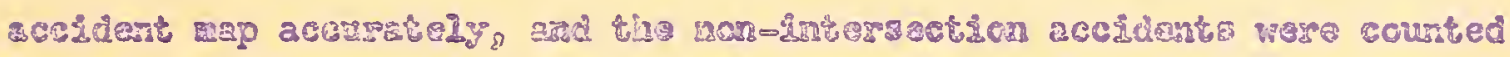

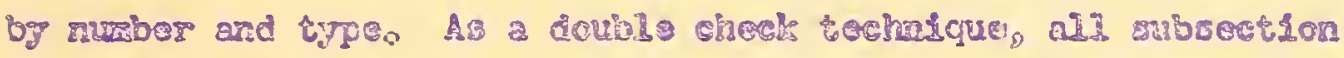

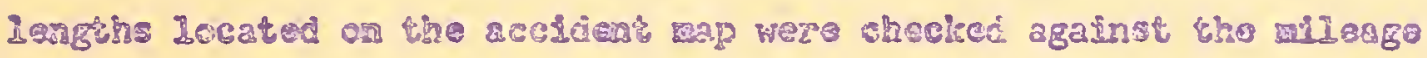

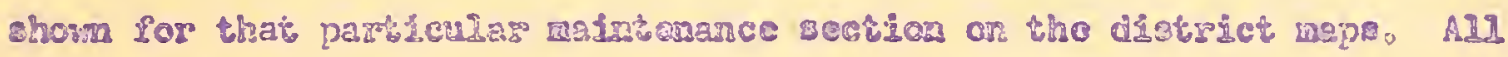

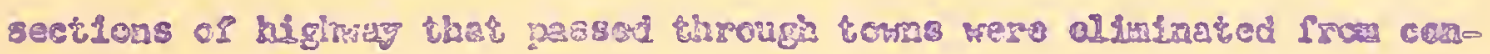

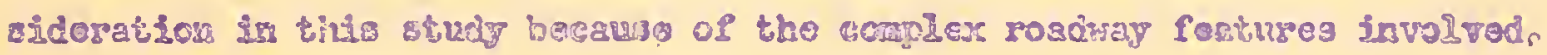

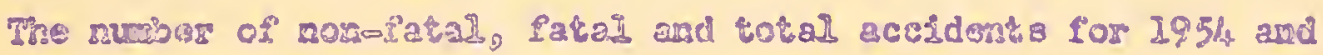

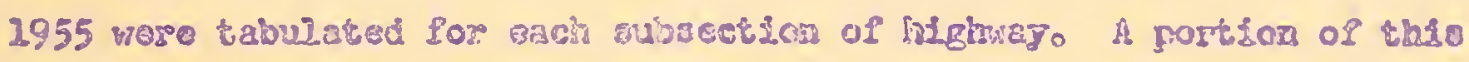

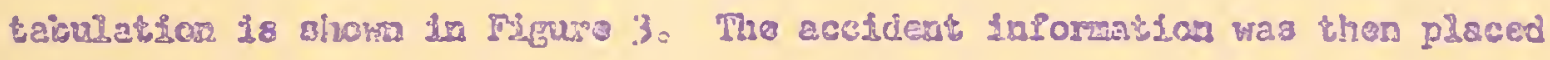
on Int cardo and the accident intos doslred vers calculated by rechlno.

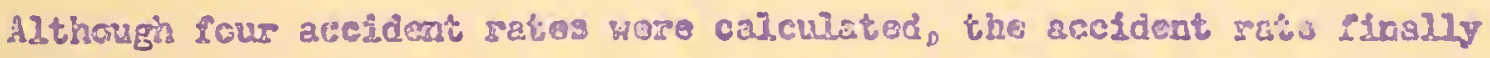

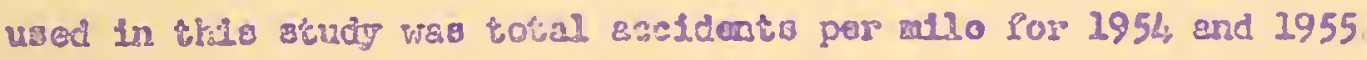

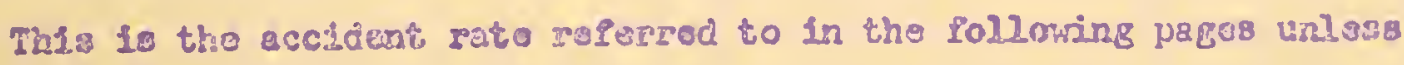
specificaliy stated othosices,

Por taindating and analysio purposes, all. eubsestions wero grouped 


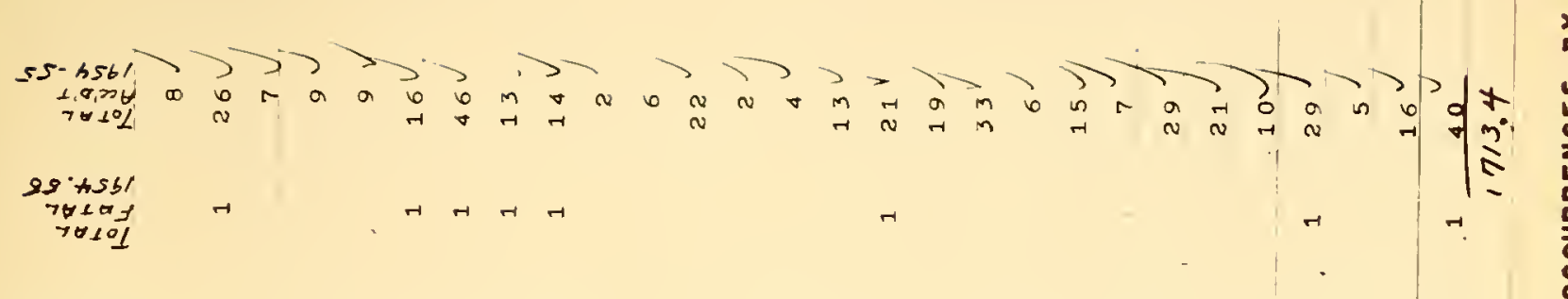

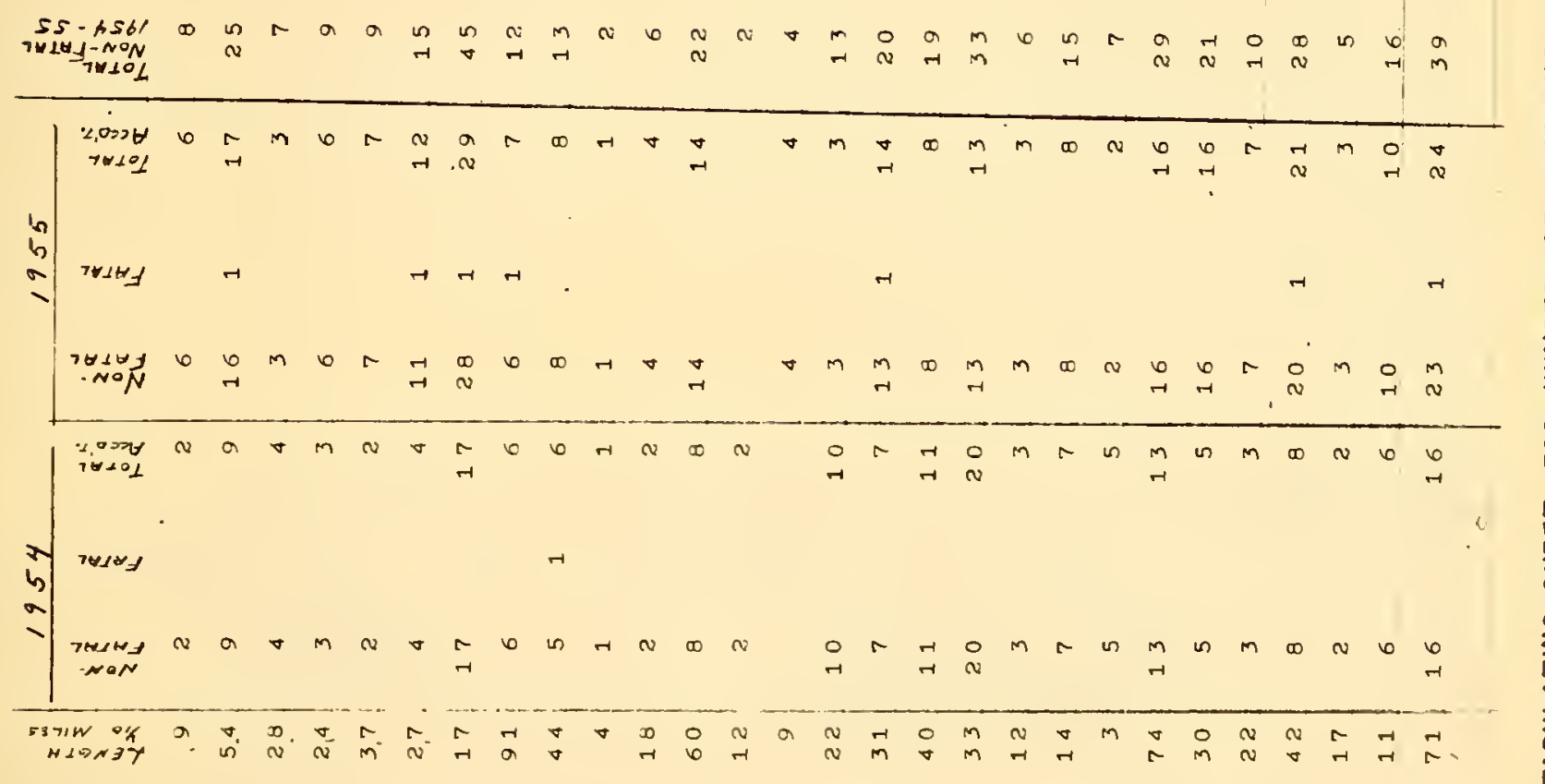

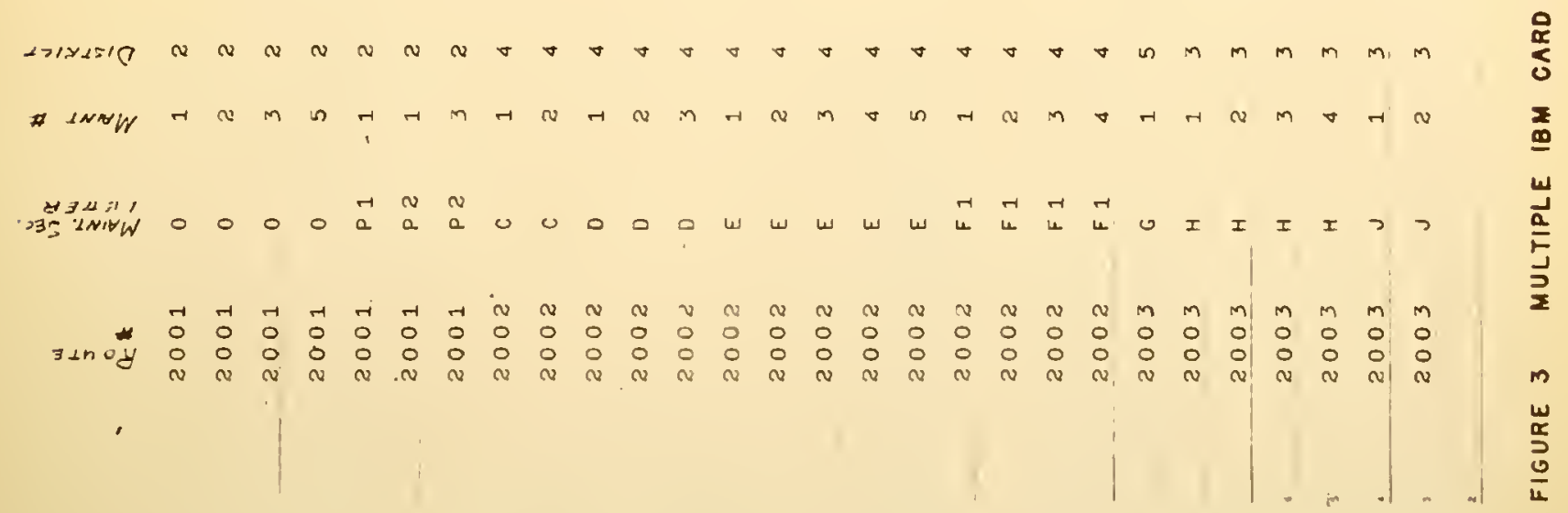




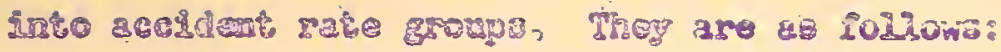

Acordent 135. Grorp

1

3

4

5

6

\%

6

9
2

(1)

4

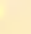

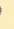

T

(1)
Tot Al Aceidsat Rate For 2989 ind 7955

$$
\begin{aligned}
& 0=1.9 \\
& 2-2.9 \\
& 3=3.8 \\
& 4=409 \\
& 5-509 \\
& 6=7.8 \\
& 80.9 \\
& 20=13.9 \\
& \text { 24. arza abors }
\end{aligned}
$$

\begin{tabular}{|c|c|c|c|}
\hline 18 Crois: & \multicolumn{3}{|c|}{$\begin{array}{l}\text { Anzuel Avgrage Da5n } \\
\text { Traffic Volve }\end{array}$} \\
\hline 1 & 0 & $\infty$ & 399 \\
\hline 2 & $2, \infty, \infty$ & $\therefore$ & 10999 \\
\hline 3 & 2,000 & $=$ & 28999 \\
\hline 4 & 3,000 & $\infty$ & 3,999 \\
\hline 5 & 40000 & - & 4,999 \\
\hline 6 & $5_{8} 000$ & $\infty$ & 5,999 \\
\hline$?$ & 6,000 & - & 6,999 \\
\hline 8 & 7,000 & & 7.989 \\
\hline 9 & 8,000 & end & abore \\
\hline
\end{tabular}

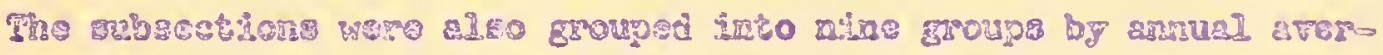

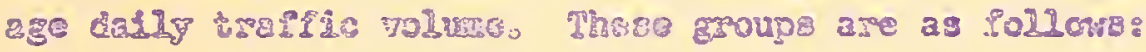




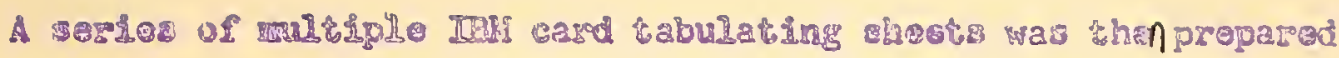

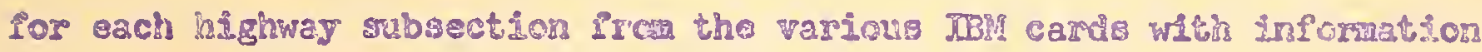

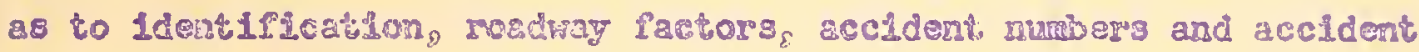
rates, A sample for asch typo of rulthple TBur cabulating sheot for

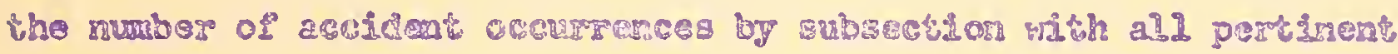
information grouped ty amnta

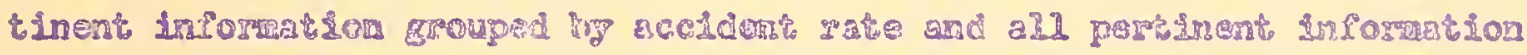

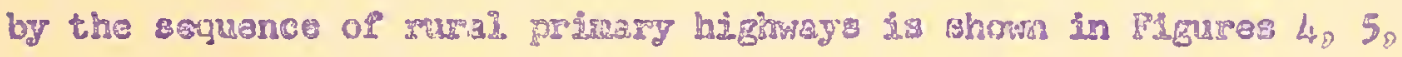
anci 6 respect

As an ald to a better maeratamcing of the procedure, the linforma-

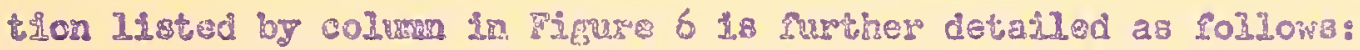
A. Identification

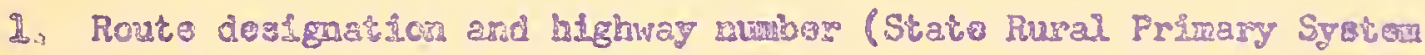
ond.

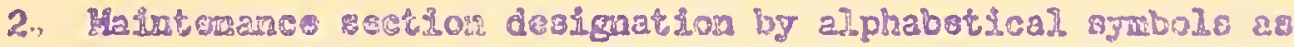

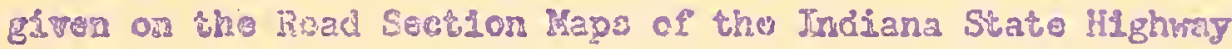
Departuento

3. Subsection designations by numbr which woro dotornined by ovm Juatios of the harsogmolty of roadway iactorgn

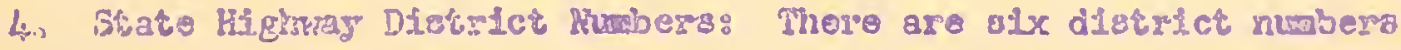
a8 Lolloirs:

Crawfordavilio
Pore Wayne
Grounfleld
LaForte
Seycuour

Vincernos 6 


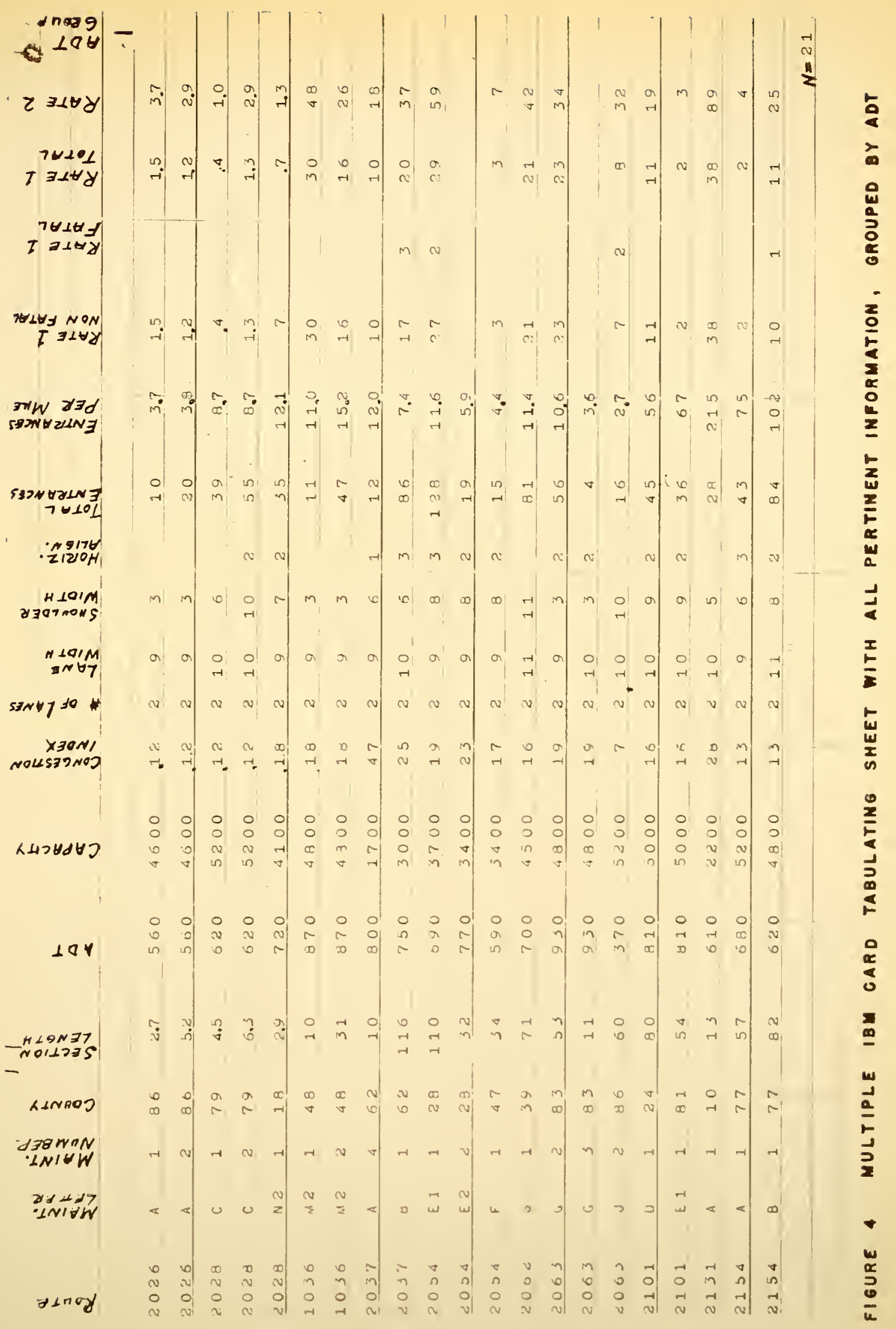




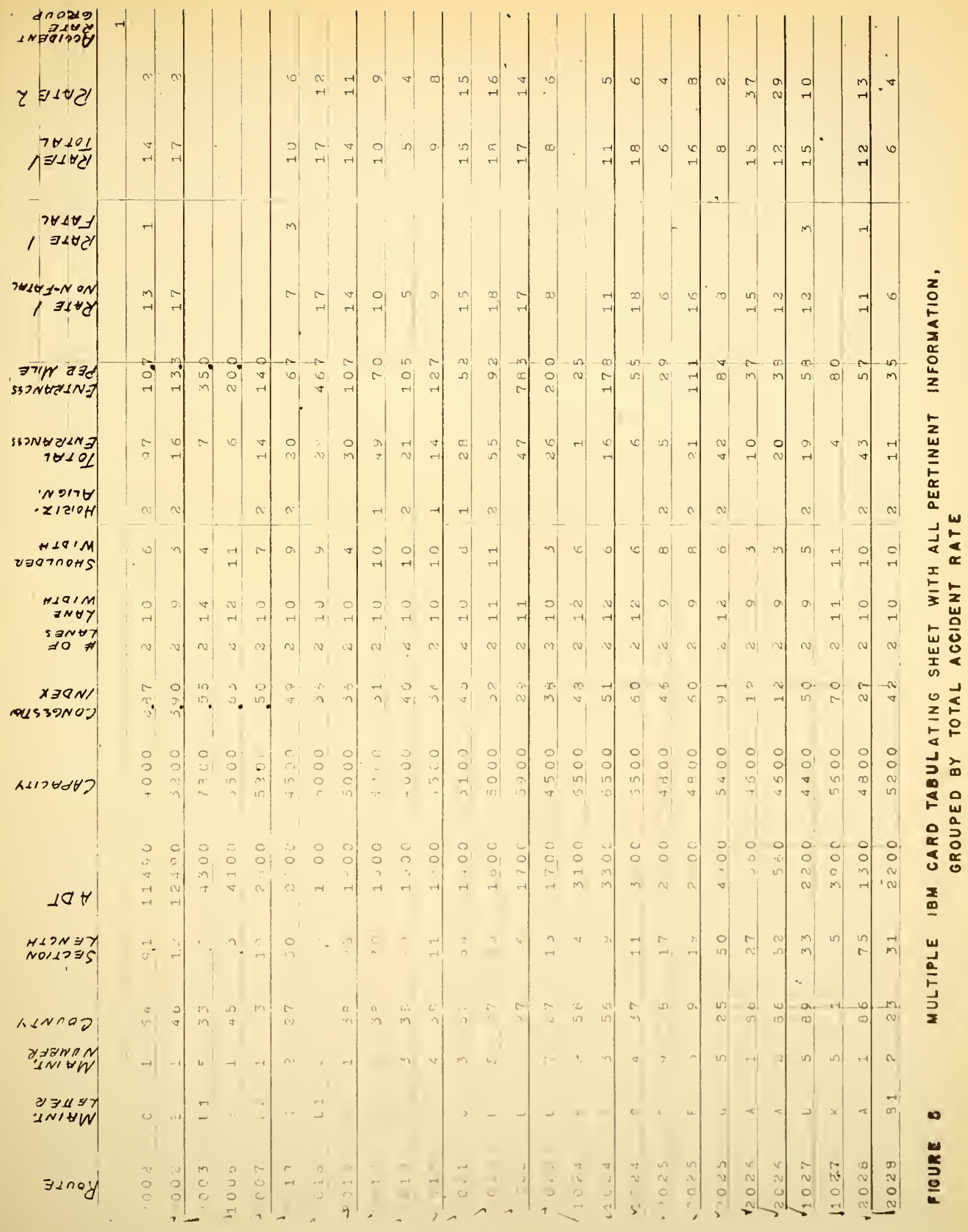




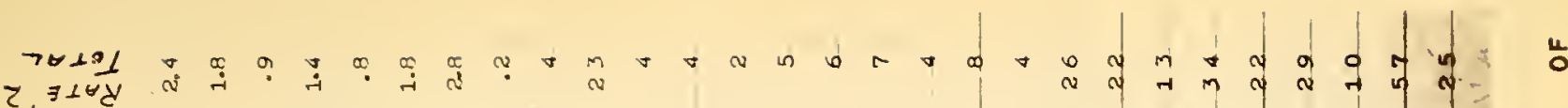

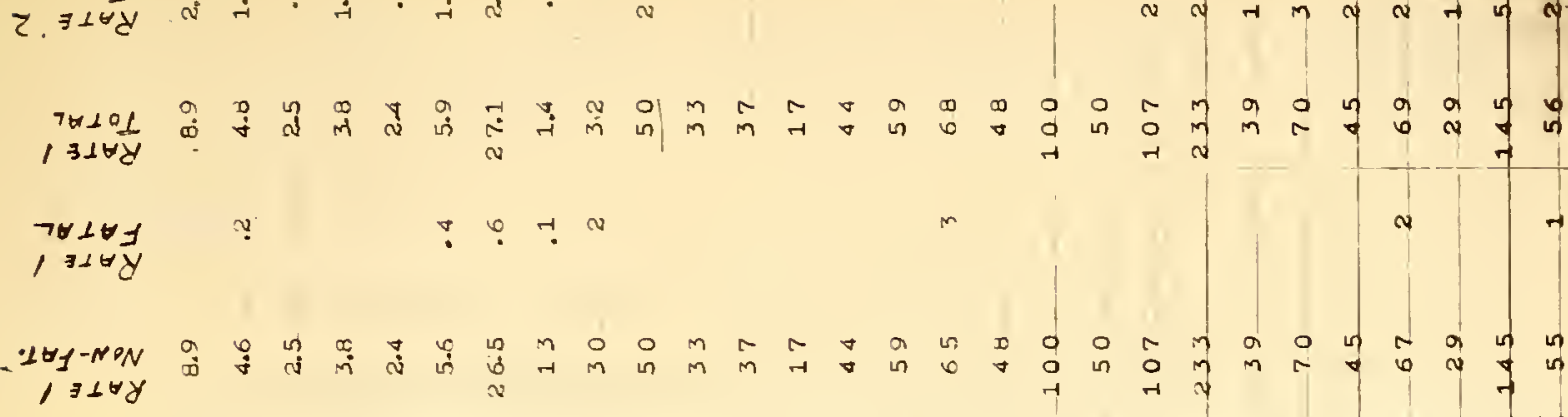

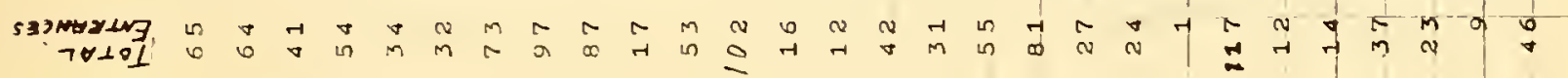
$\cdot 2,2104$

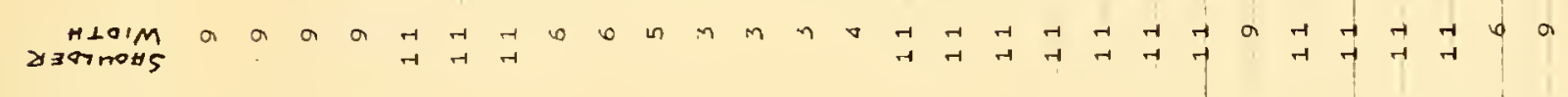

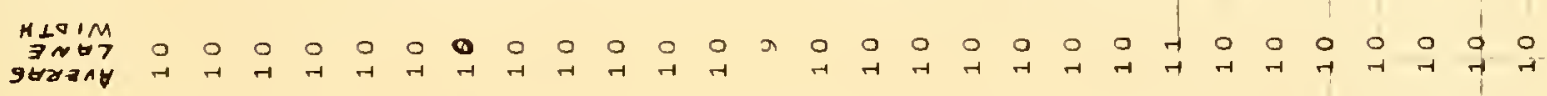
30
$3 n$

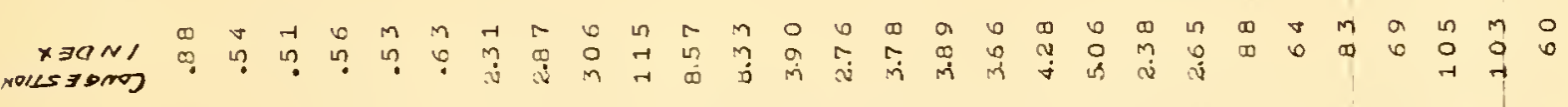

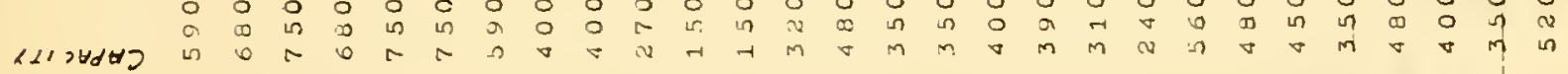

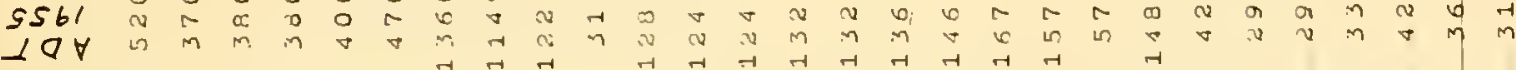

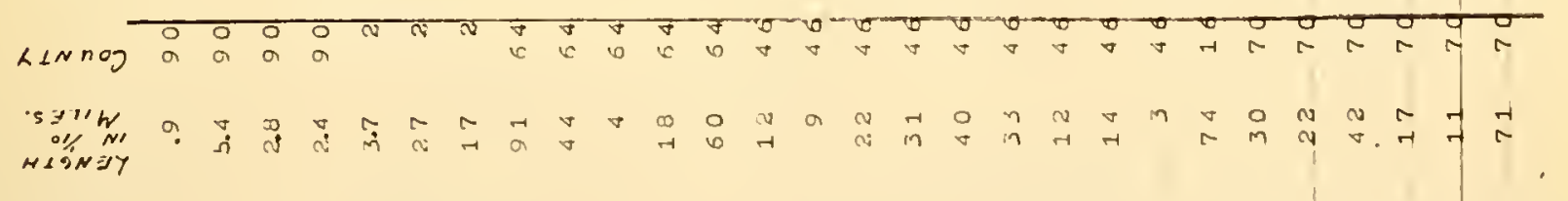

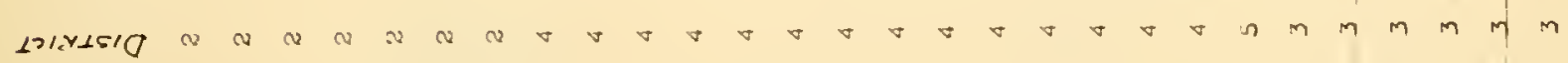

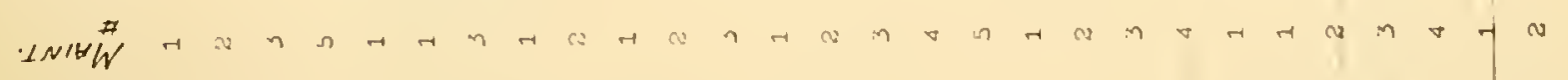




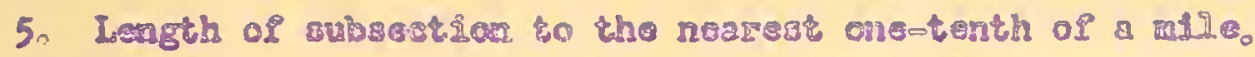

6. Hinety two countios in indiana havo baea coded alphabetically Prom 01 to 92 。

\section{B. Boadwa Pgctorg}

1. ADr (annual arerago dally traffic rolves) we talsa from Stato Higtway Daparturat Traffic Flow Hap3 for 1955.

2. Capselty was compted following the conegpts of the Highws Capacity Manual, Uo S, Departimant of Cormoree, 1950 。

3. Congest1on Indox was computed by difiding ADT by capsediry.

4: Lumbsr of travel Ianes.

5. Average lan with was found by dividing the aurface widis bs number of larse,

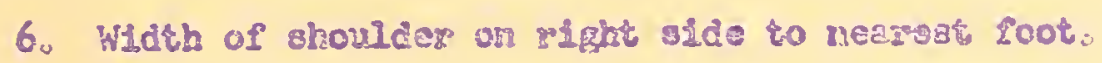

7. Homizonia allantert wes coded as follows: (a non-eritical. was one that did not necersitate a rocluction tis normal speed).

Eparuency of Curres

Hone

Ono curve, non-critical

Two to continuolie curves, non critical

Conitnuous currog loos than one-half critical

Coniknuous curpos, more than one half crition?
Code

0

1

2

3

4

8. Totol muiver of entrances on left and right divided by the subsection length. 
C. Accidont Rak̂s

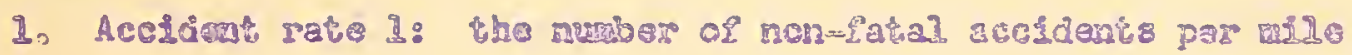
for 1954 and 3955 .

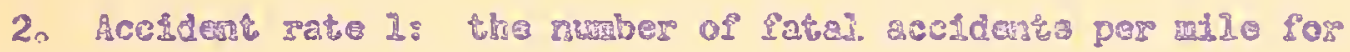
3954 aถd 19550

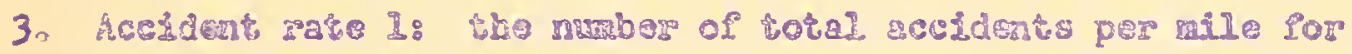
1954 and 3955.

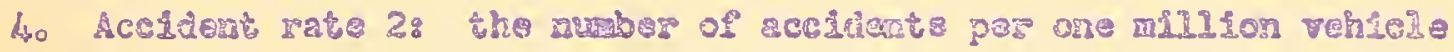

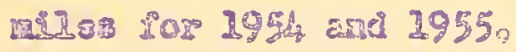

P0.

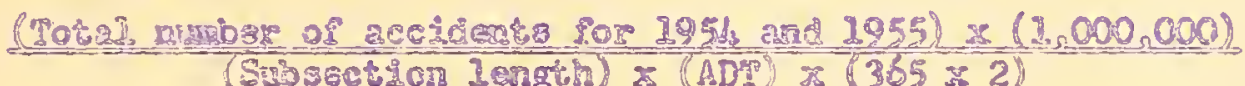

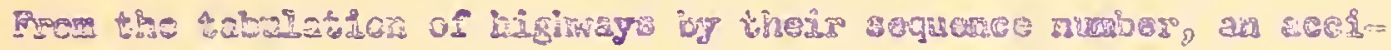

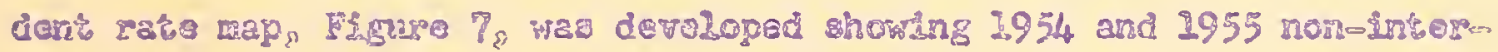

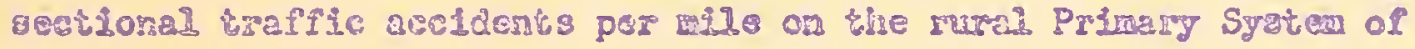
Indjaaㅛ

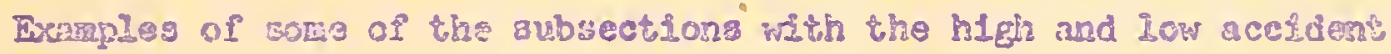

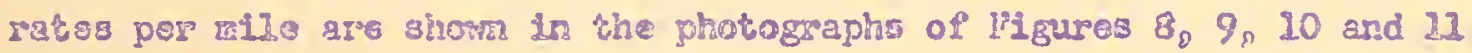




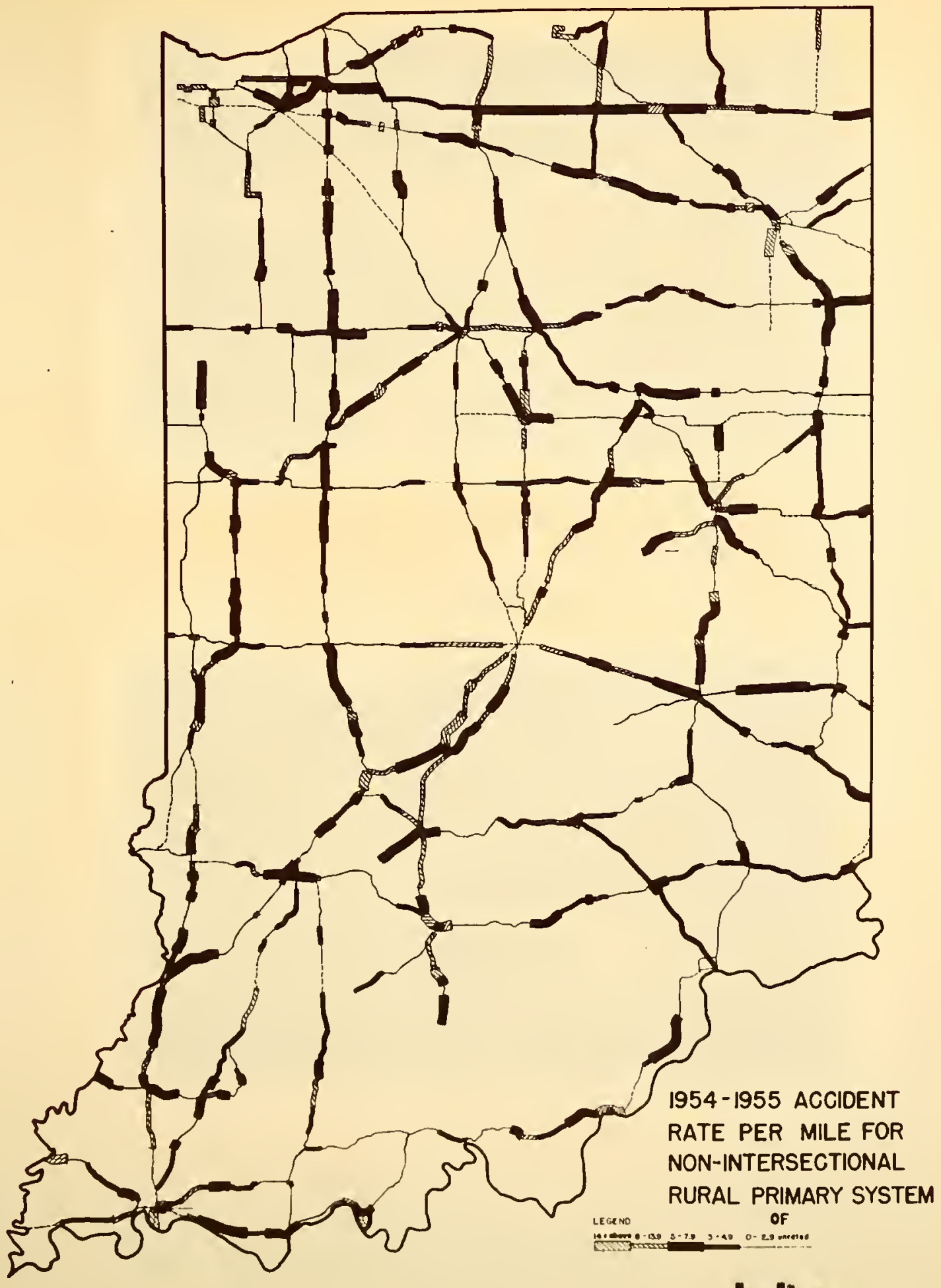

Indíana 

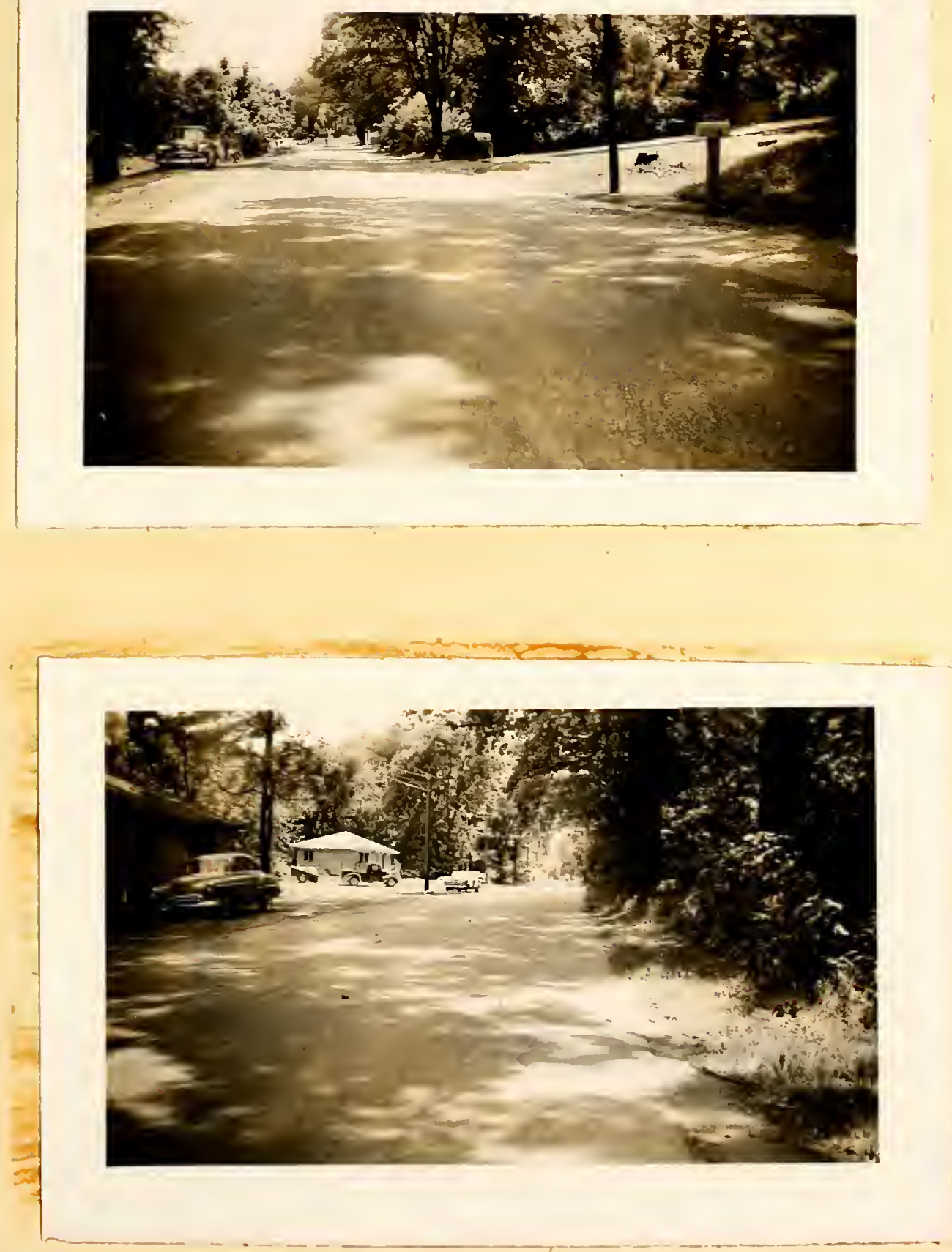


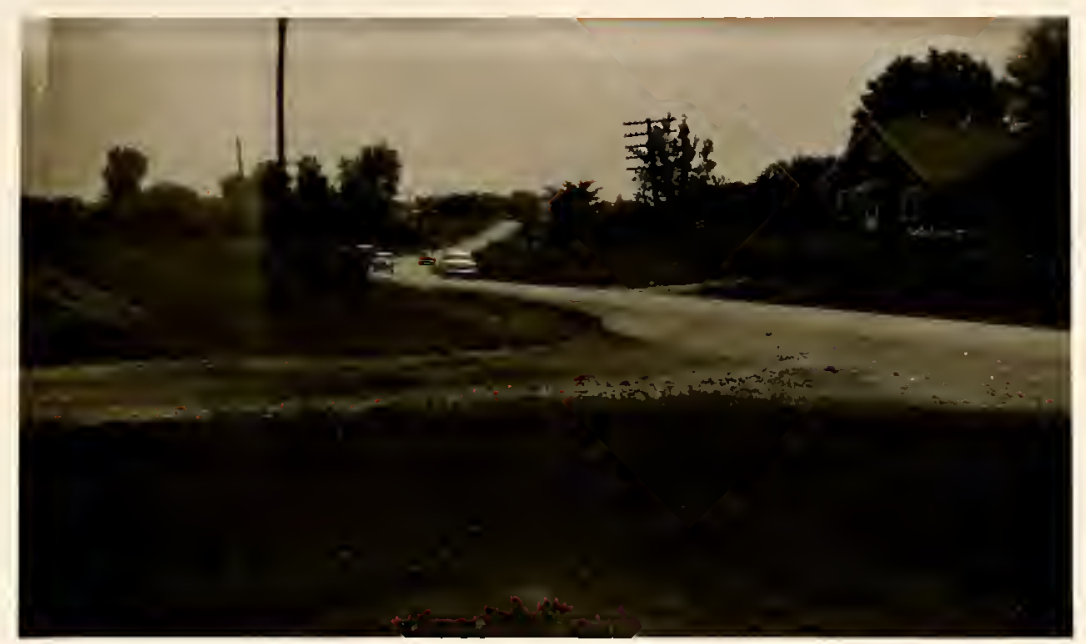

8

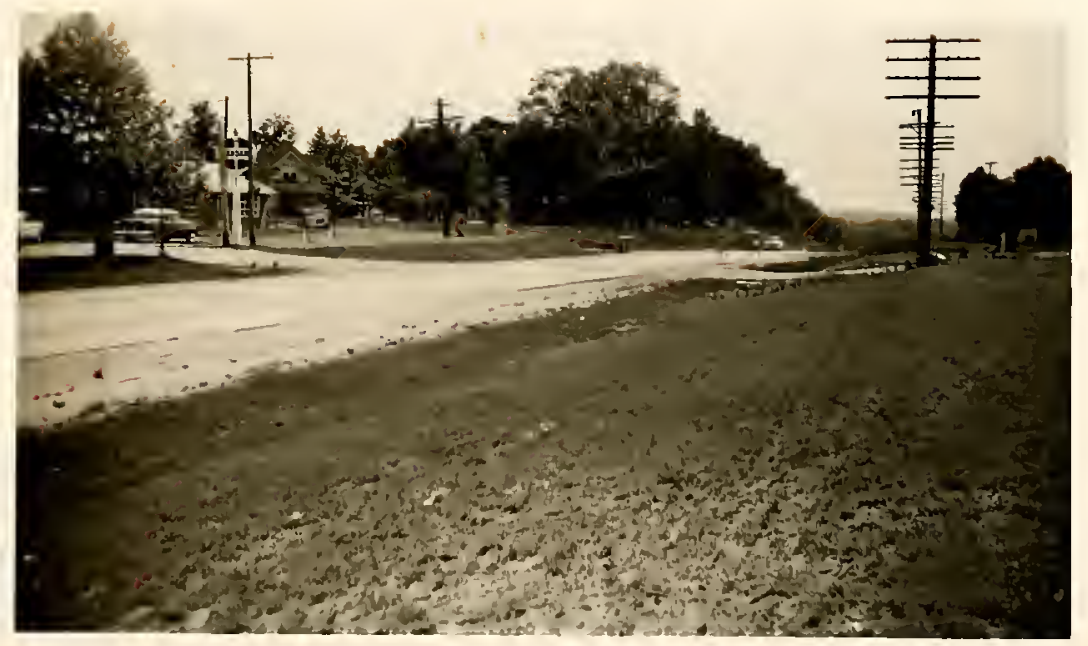

Figure 9. A Second Exrwple of a Highway Iron the Highost Accicient Rate Group ( $\Omega_{4}$ and above). Accident rate of 22,0 ; noto aunerous rosowas ontrances and curve"

(SR 25, Subsoction C2) 


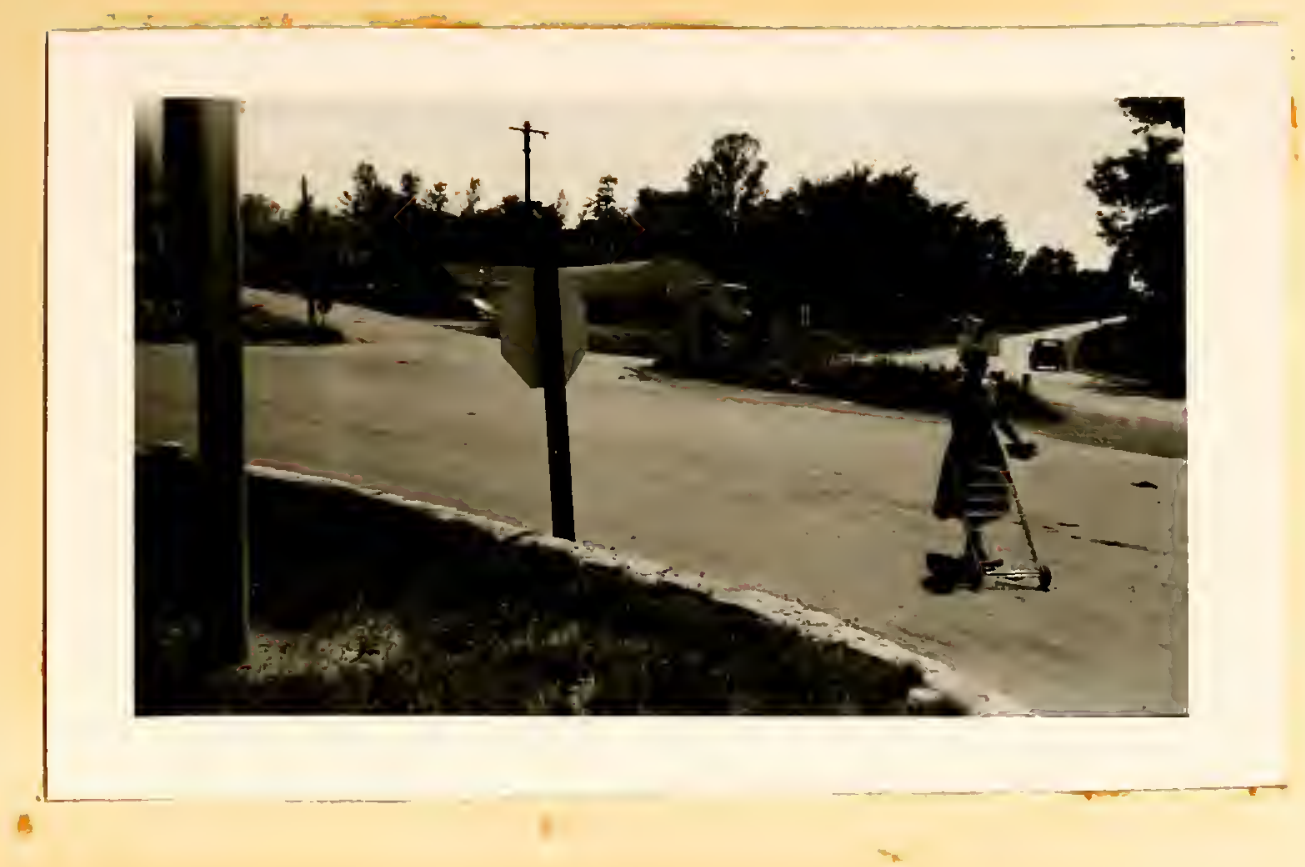

s

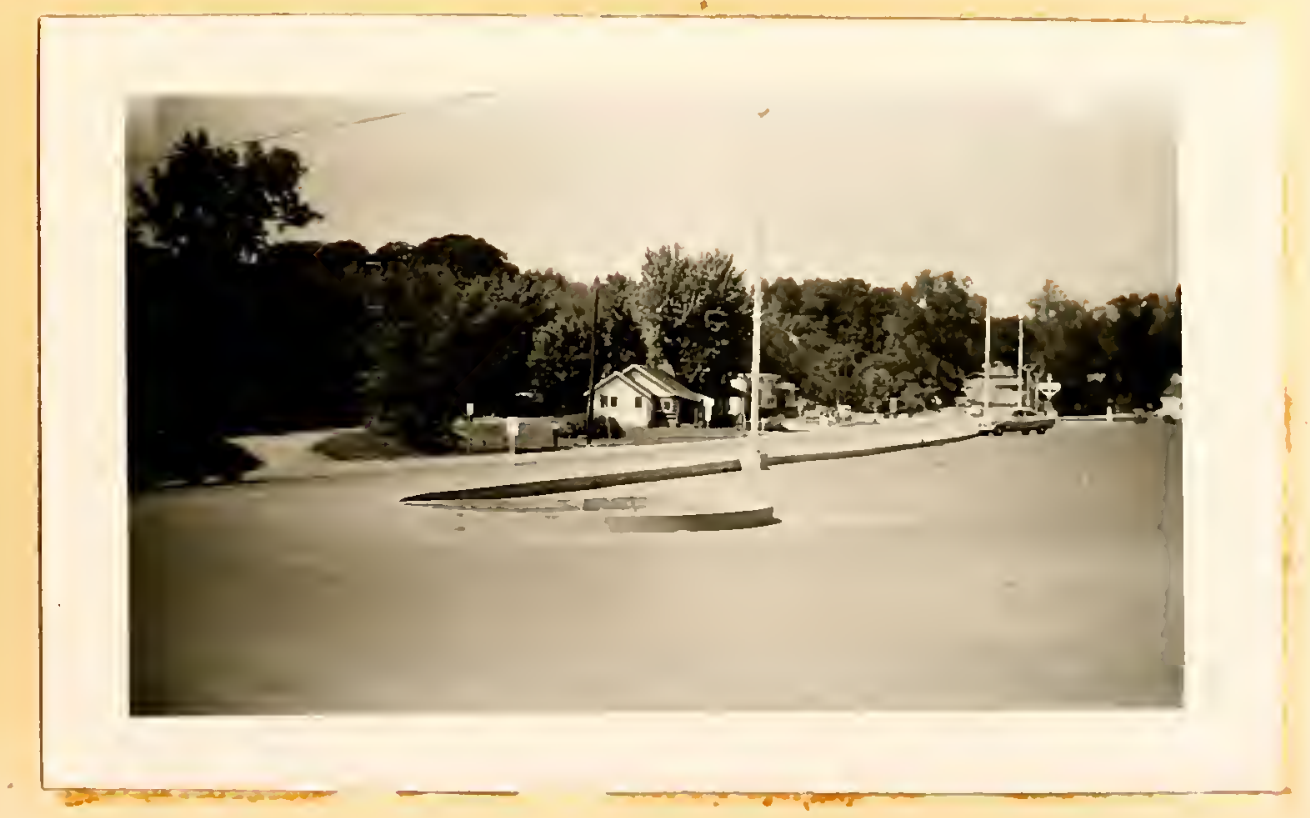

Figure 10. A Third Exarplo of a Highwas from the Highest Accident Rato Group ( 14 and abovo), Accident rate of 35.0 ; noto combination of steop curvo and roadoide interforenees frow the shopping center.

(SR 43, Subroction K3) 

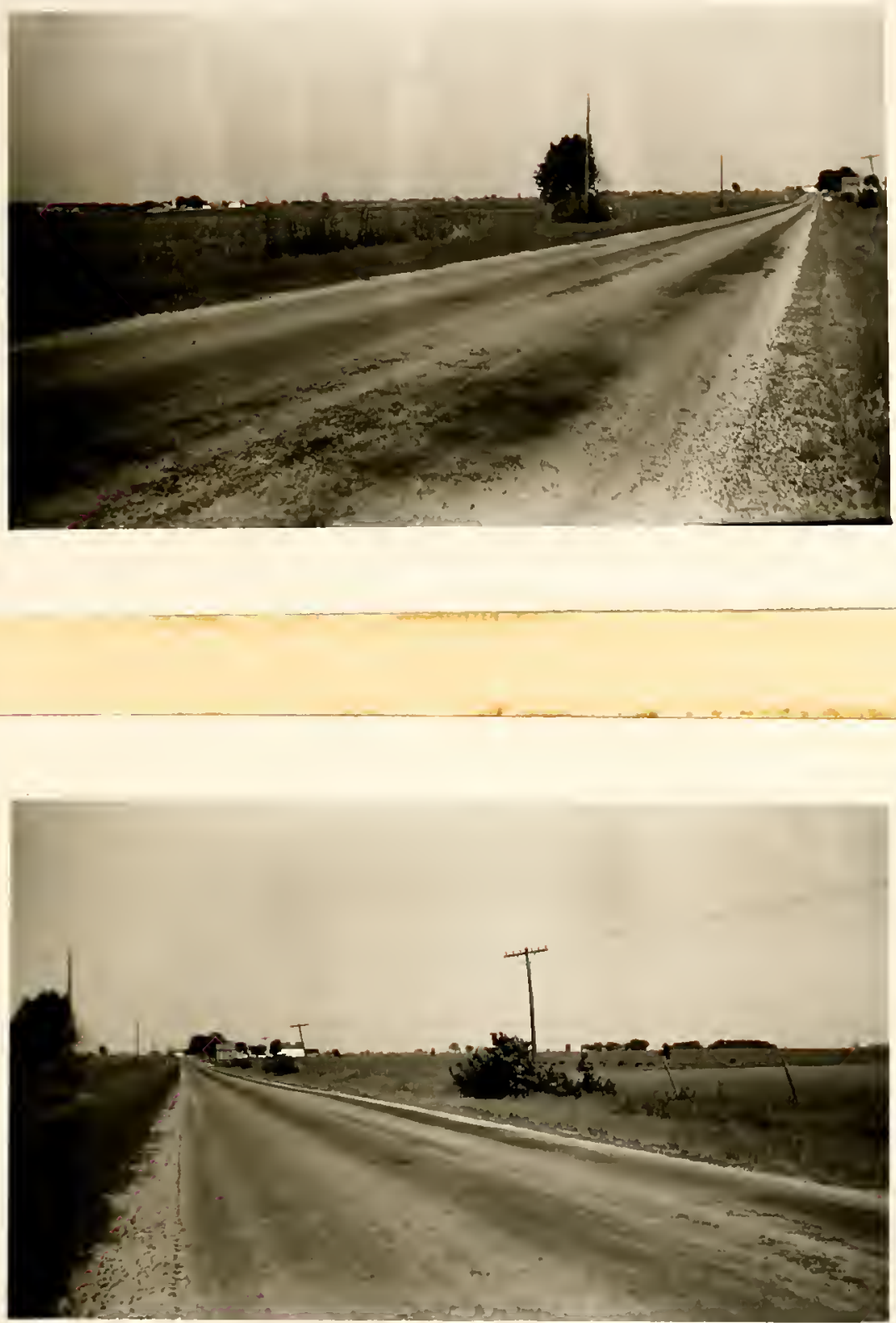

P1gare 21. An Exemple of a Highway from the Lowest Acc1dent Rate Group (below 2). Acc1dent rate of 0.3; note wide road with axcellent visibility and absence of entrances. (SR 28, Subsoction CL) 
AHAZXSIS OF THE DATA

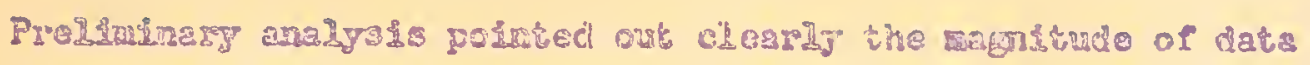

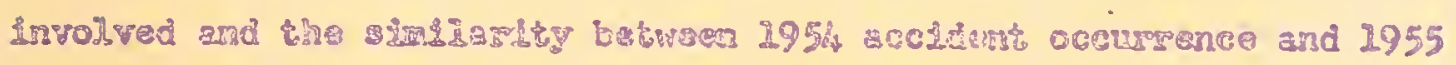

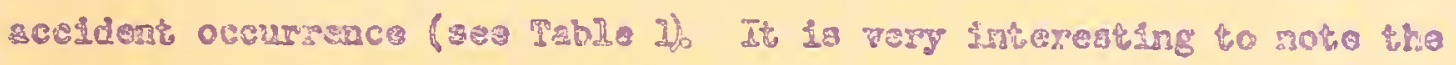

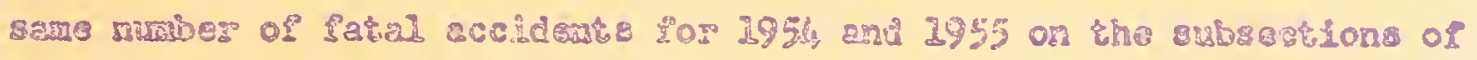

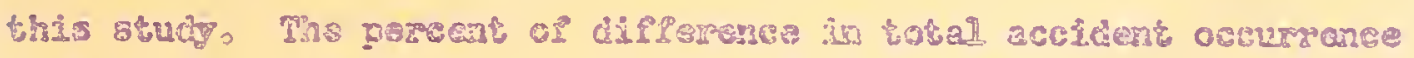

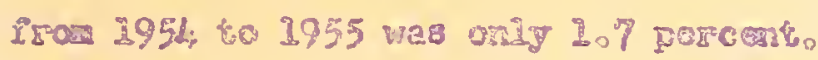

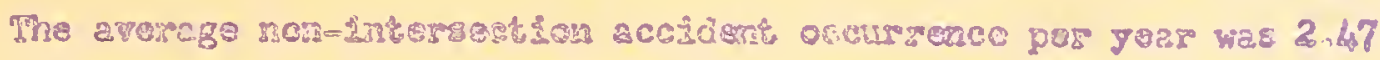

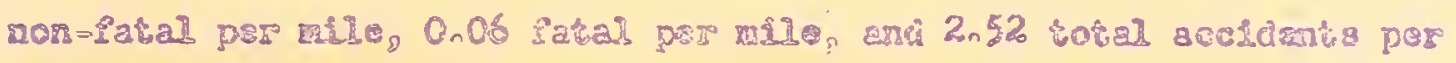

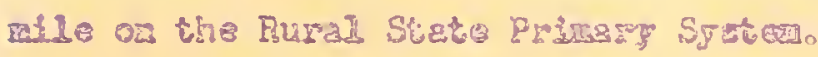

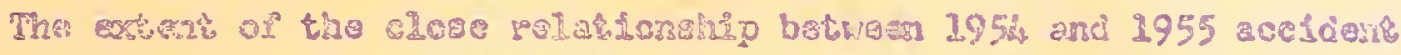

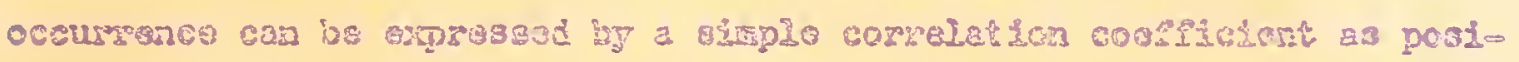

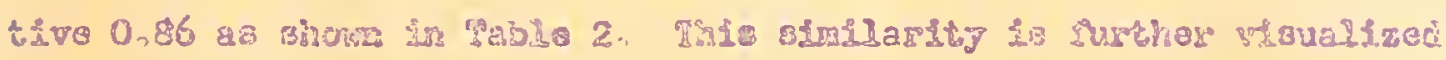

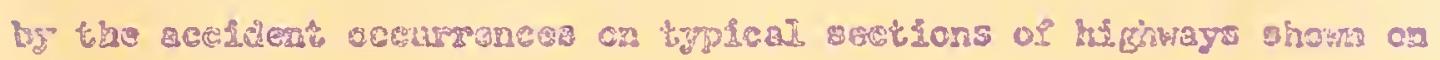
EIgtur 12 .

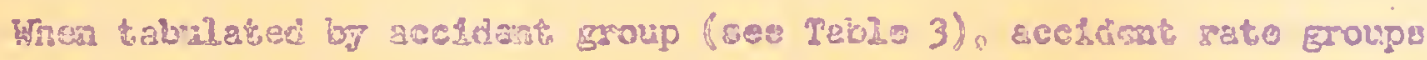

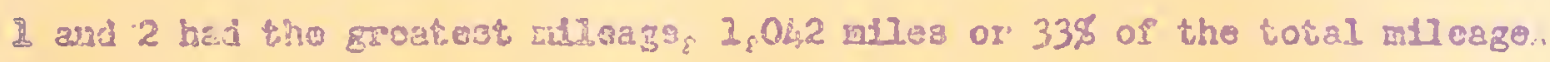

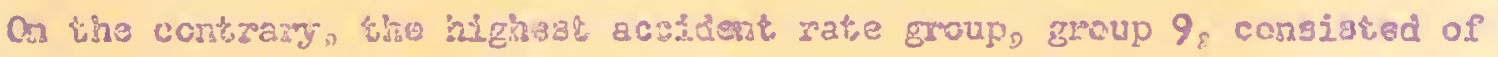
254 willes or aily of of the unbal length.

It was obeeryed that ths mean of $\mathrm{ADT}_{0}$ capecity cangostion sodex, lans width, aad total entrances per rilo increascd as the accldart rate increased,

There apseared to bo scrus gysteracic trasd botwoen accidont rate 
Tabla 3

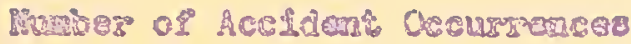

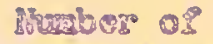

Sulosections

937
Tota?

dongth

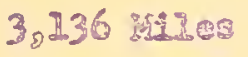

Hoss feted

Acedderics

$7681(2952)$

7724. (1255)

25455 (Fote?)
Fृand Accidguts Accidents

1.83 (2954) 7844 (2954)

$183(1954) \quad 7277$ (1925)

366 (Toten) 15823 (

Ratio of nom-pasal to iatal accldents: 42 to 1. 
Table 2

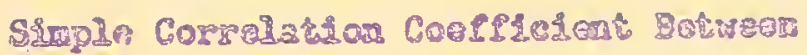

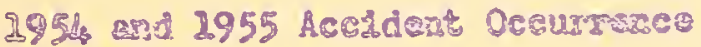

\begin{tabular}{|c|c|}
\hline & 29.8 \\
\hline Tobal Acstcess & 7044 \\
\hline Mean of Aceidatis psis Subsotion & 7.95 \\
\hline 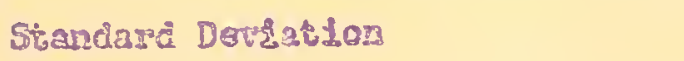 & 8,72 \\
\hline
\end{tabular}

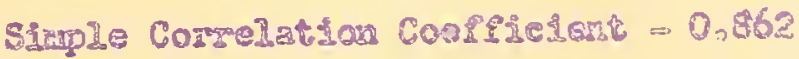

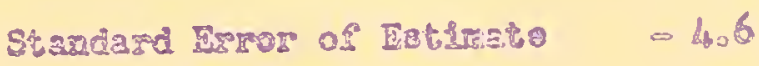




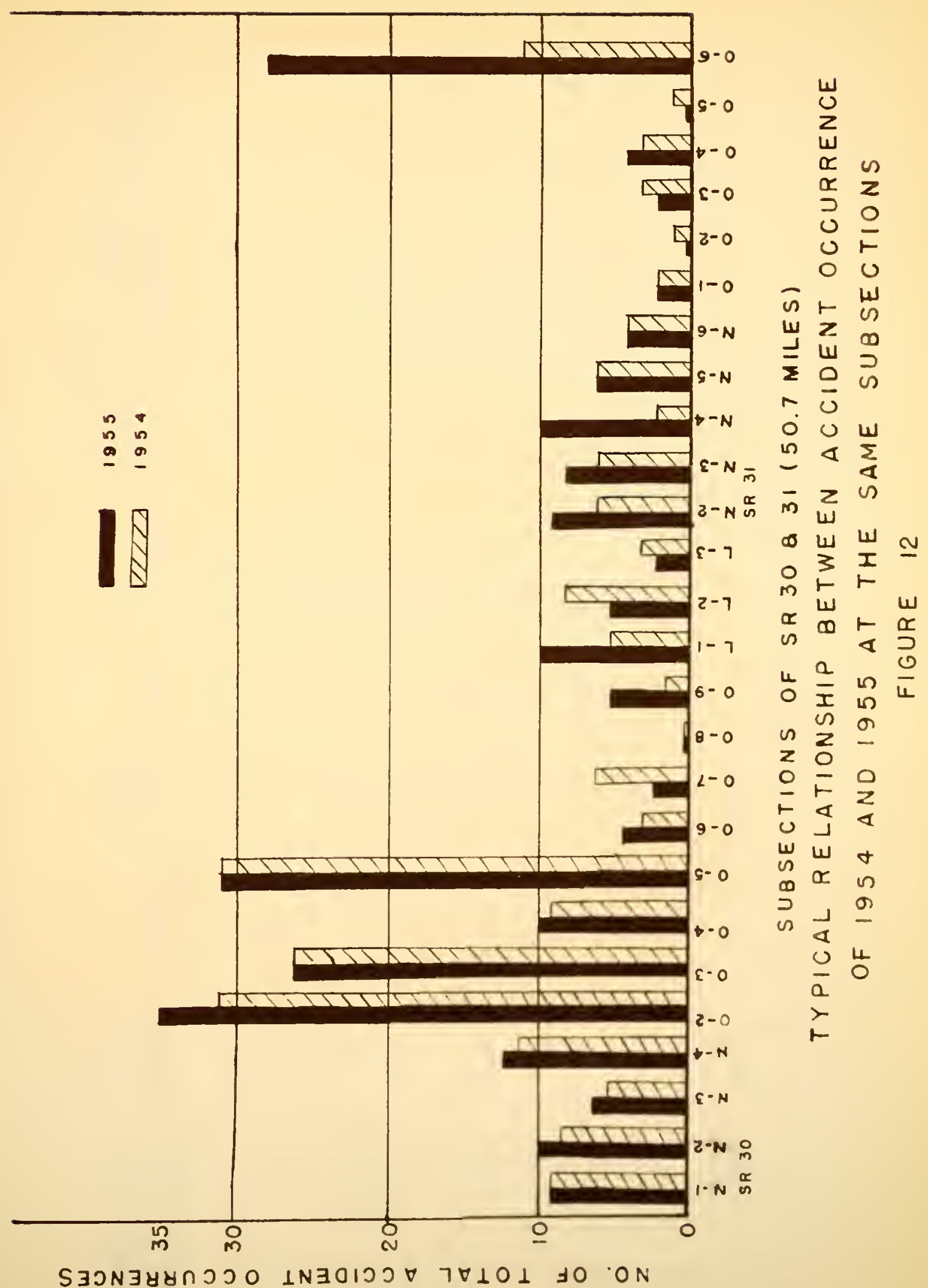




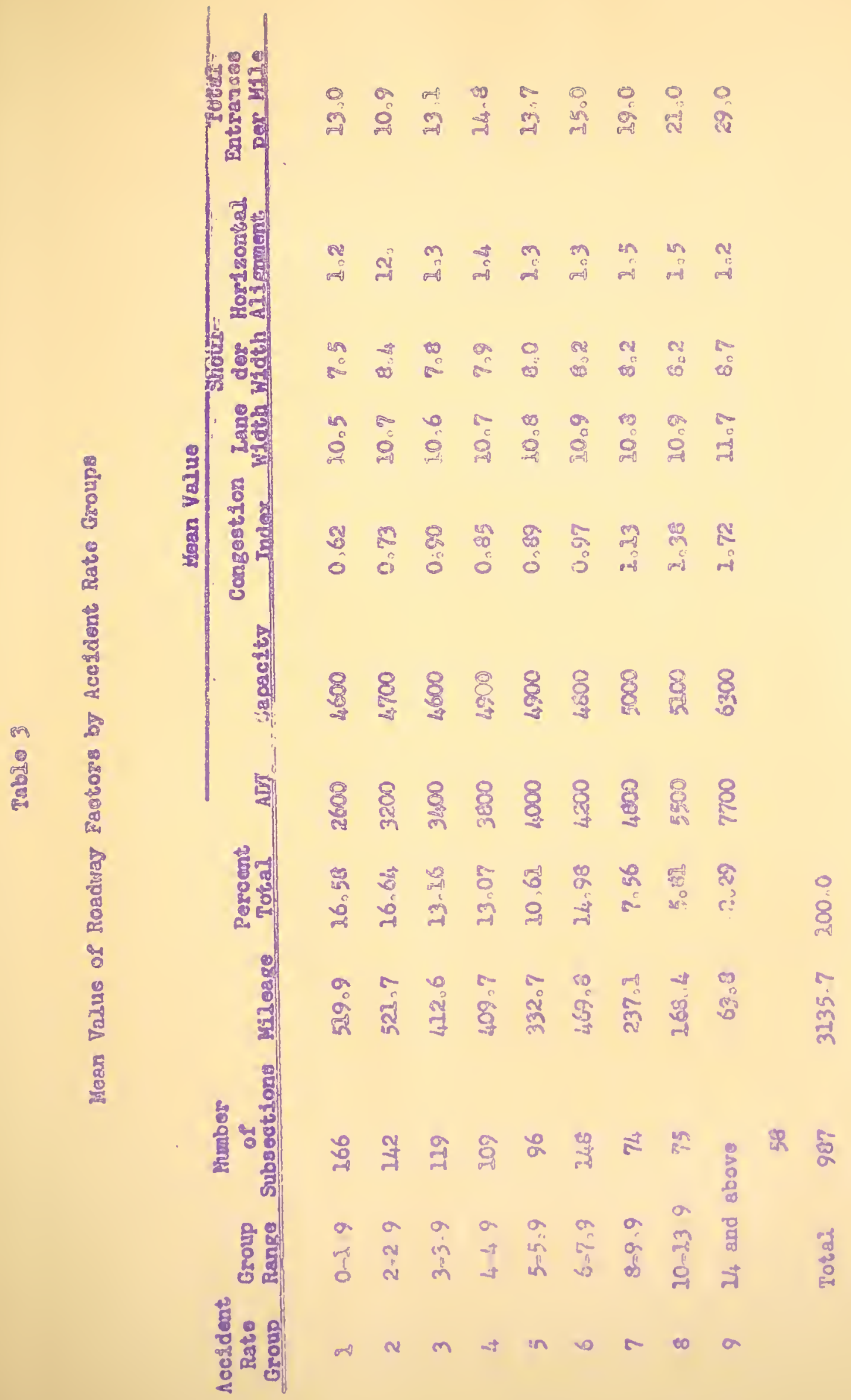


Broup and Increace of ADT, A Btuty of tho vastation of ADT withis

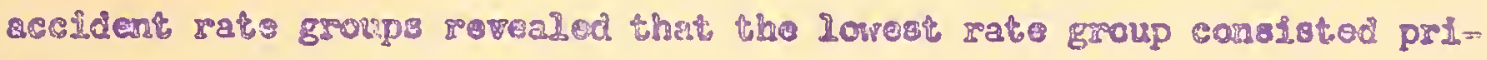
warhly of rosde whth an ADr 560 to 4900 with a fow higher voluses. The Bighest aecidert group had a range of ADT 1400 to maty with a wolver of 20,000 0

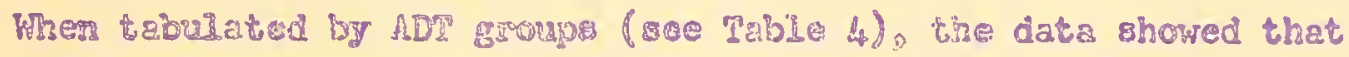

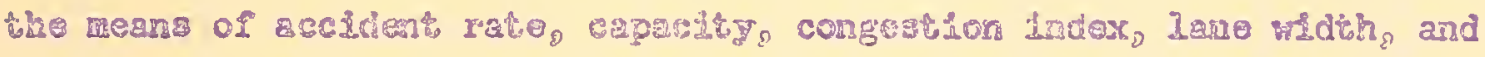

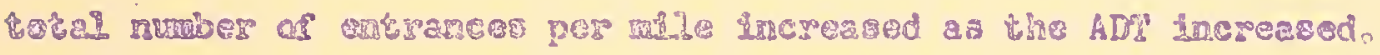

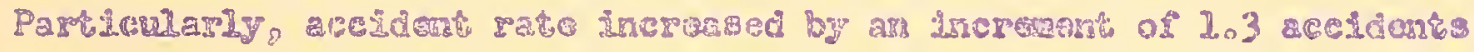

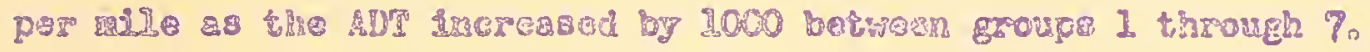

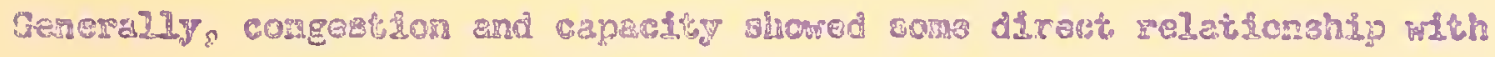

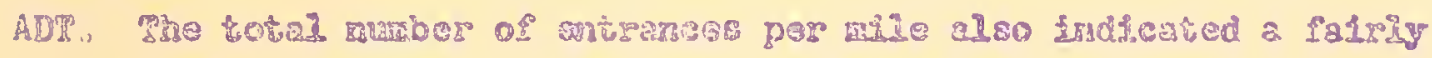

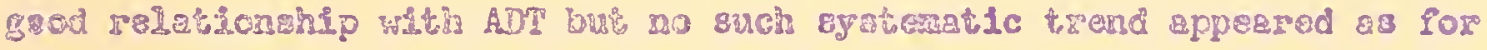
the aceldert, xate.

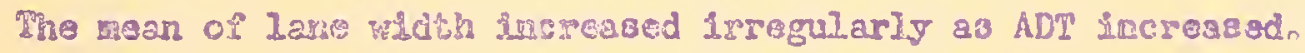
Thore ware no defingte trends for ghouldar wath and hordzontal allgriant.

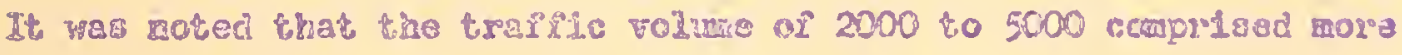
than one daje or all accidert rates and total wilesge.

Tntestigation of the Earietion of aceldants within cach ADT group rovealed that the 1.0ront ADI group hed a range of 0 to 3.8 accident

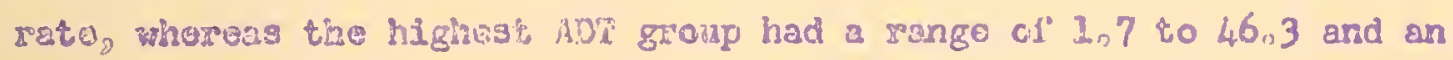
axcejtional rate oi 165,0 . 


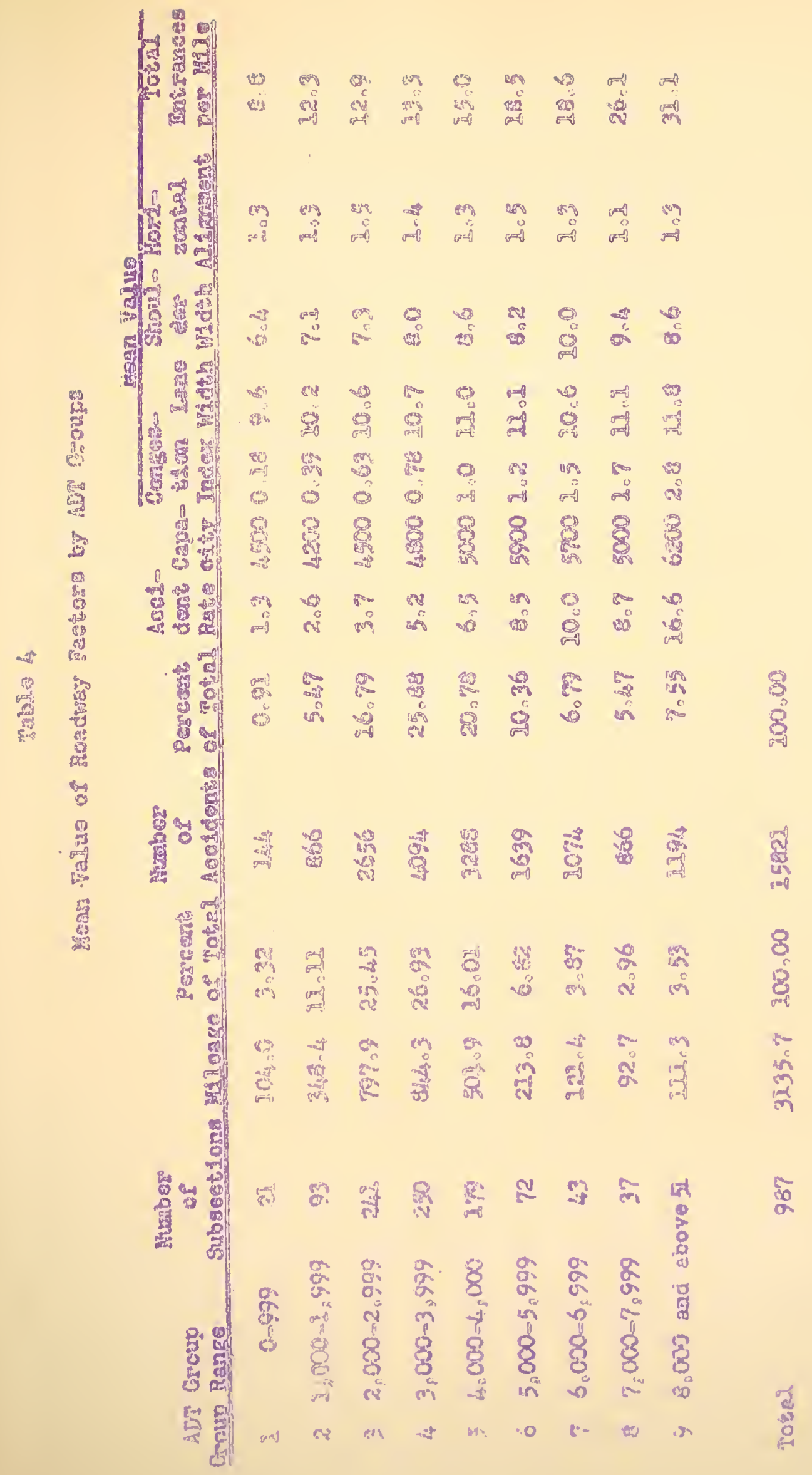




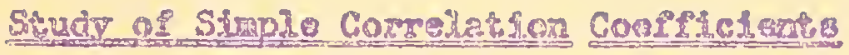

This part of the otudy wes aiade to deterating the ralationehto

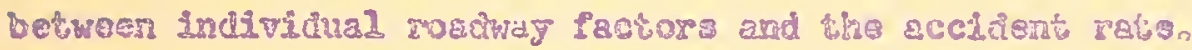

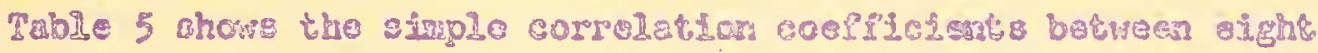
reaorar fretore and sour types of acciden rates. The corrolation

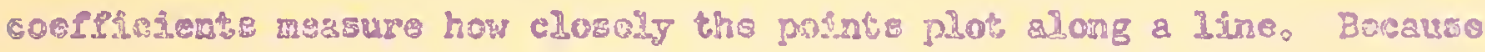

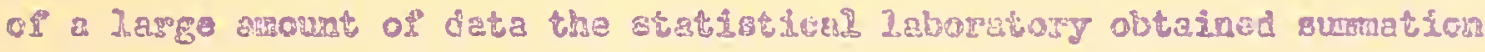

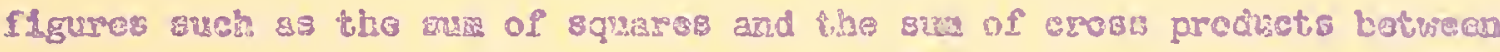

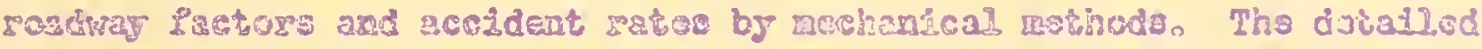

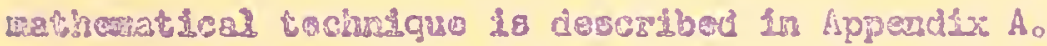

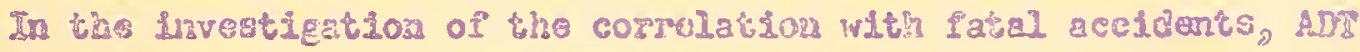

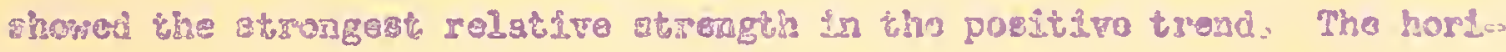

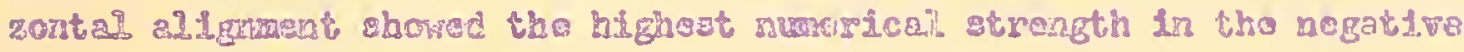
trond, indicating ther were lesis fatas accidents a the curvaturo in eresed. It shoudd bo noted, howerer, lint tho evaluation of horizontal alignant was difficuit and on tho basis of quantity of curves. The

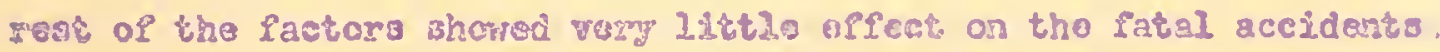

As for tha non=fatal accldests, the rulationship of the roadway factors to acciden rates rere all in a posttro direction. ADI and congestion fudex showed the sisrongest relationship, On the contrary capesty, shoulder whth and horlzcacal alsigment ohowed vary littlo relat fonship cetpared to other factore: thol of focts wor sppraximstaly cre twentieth of the ADT and one flfth of this offoet of lane whdth and total entrences par nillo. 
This?

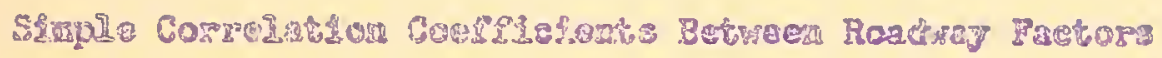

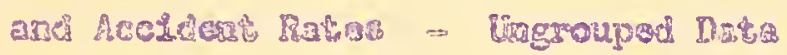

\begin{tabular}{|c|c|c|c|c|}
\hline Rosimer Foofos & Morof fate & EstaI & $\begin{array}{c}\text { Total } \\
\text { Acciders }\end{array}$ & 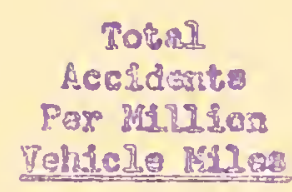 \\
\hline$M D I^{\circ}$ & 0.466 & 0.292 & 0.452 & $=0.053$ \\
\hline Capactsy & 0.082 & 0.066 & 0.083 & .0 .076 \\
\hline Congerston Index: & 0.429 & 0.067 & 0.432 & 0.048 \\
\hline Geviogs of Lanez & 0.272 & 0.065 & 0.173 & 0.025 \\
\hline Lane vidith & 0.239 & 0.058 & 0.201 & 0.04 \\
\hline 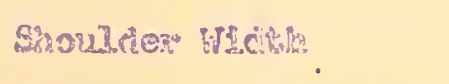 & 0.027 & 0.090 & 0.024 & $=0.058$ \\
\hline 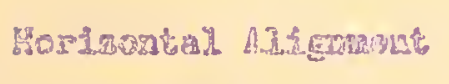 & 0.025 & $=0,34$ & 0.024 & 0.053 \\
\hline 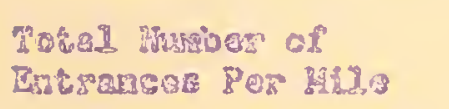 & 0.165 & 0.016 & 0,239 & $=0.023$ \\
\hline
\end{tabular}




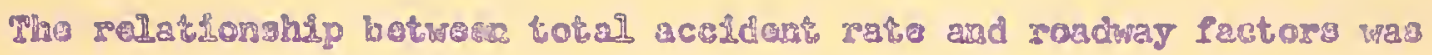

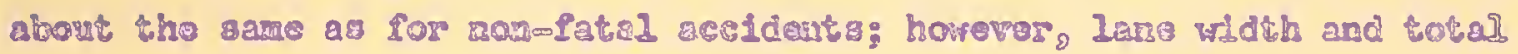

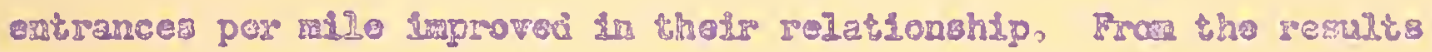

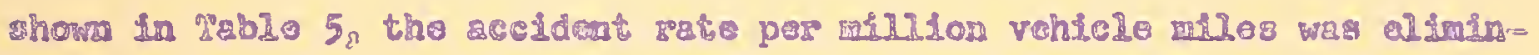

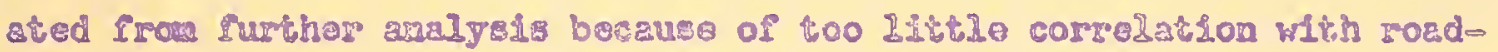

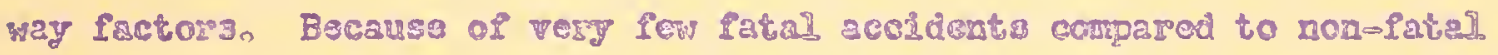
occidents, it was alwo doelded to use only total accident rate per milo Por further axalysiso

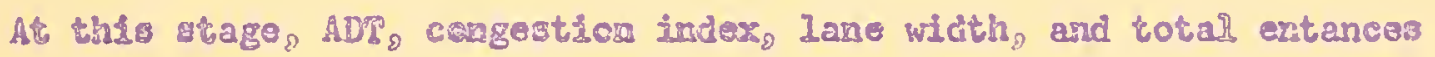
por mile Mare chozen to bo sieniflcant ractore with fotal accideat Fate.

To test the hypothesis of Innearity of rogressong an analysie of variance techajquo was used to test whother or not the wean for each

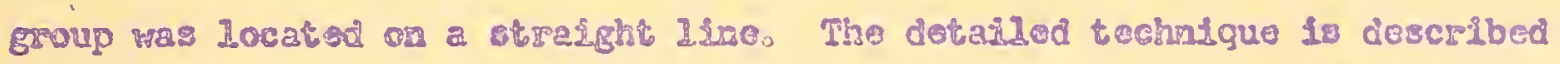
In Appendix $B_{8}$ Figure $2 B_{3}$

Phgure 13 show the scattor disgram for ADI versus total accidanto

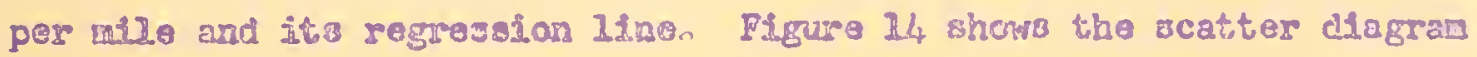

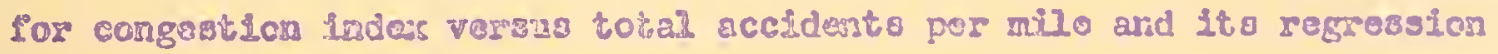
In:

Tho rosult of Fatest3 rovoniod that tho hypothosis of IInsarity was reaconsble for the gigniflcant igetors, The detalled tochniouos used In this analyo1s aro deBcribed in Appendix B. Thus, tho corrolation

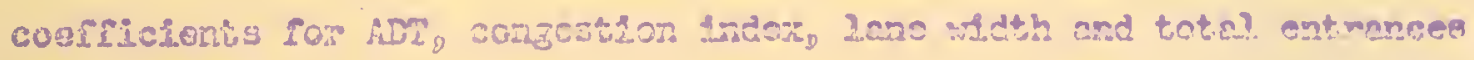
por alle shom in lable 5 for total accldent rate waro verified and found to be scceptablo.

Because the reajority of Stato Rural Primary highway conbiat of two 


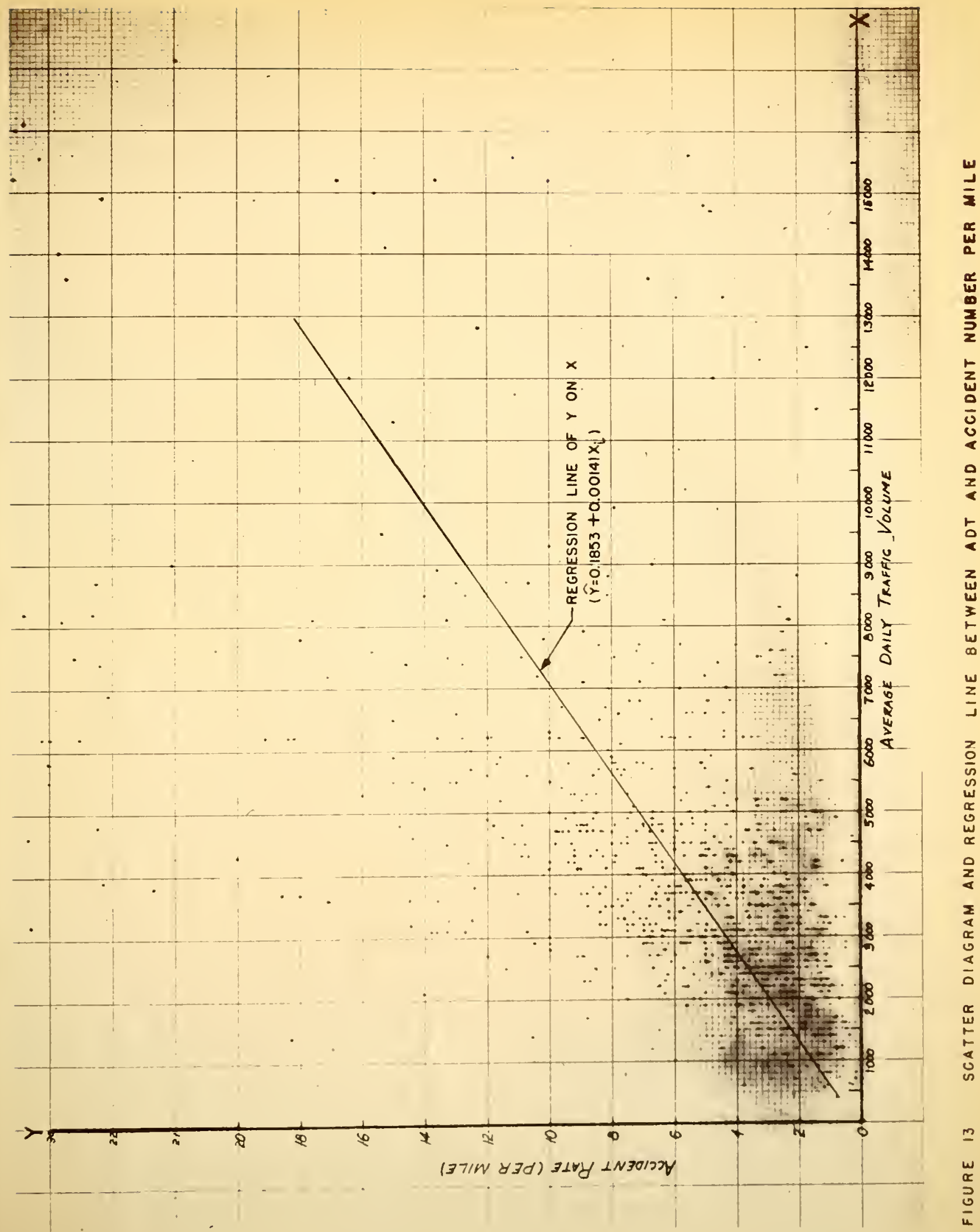




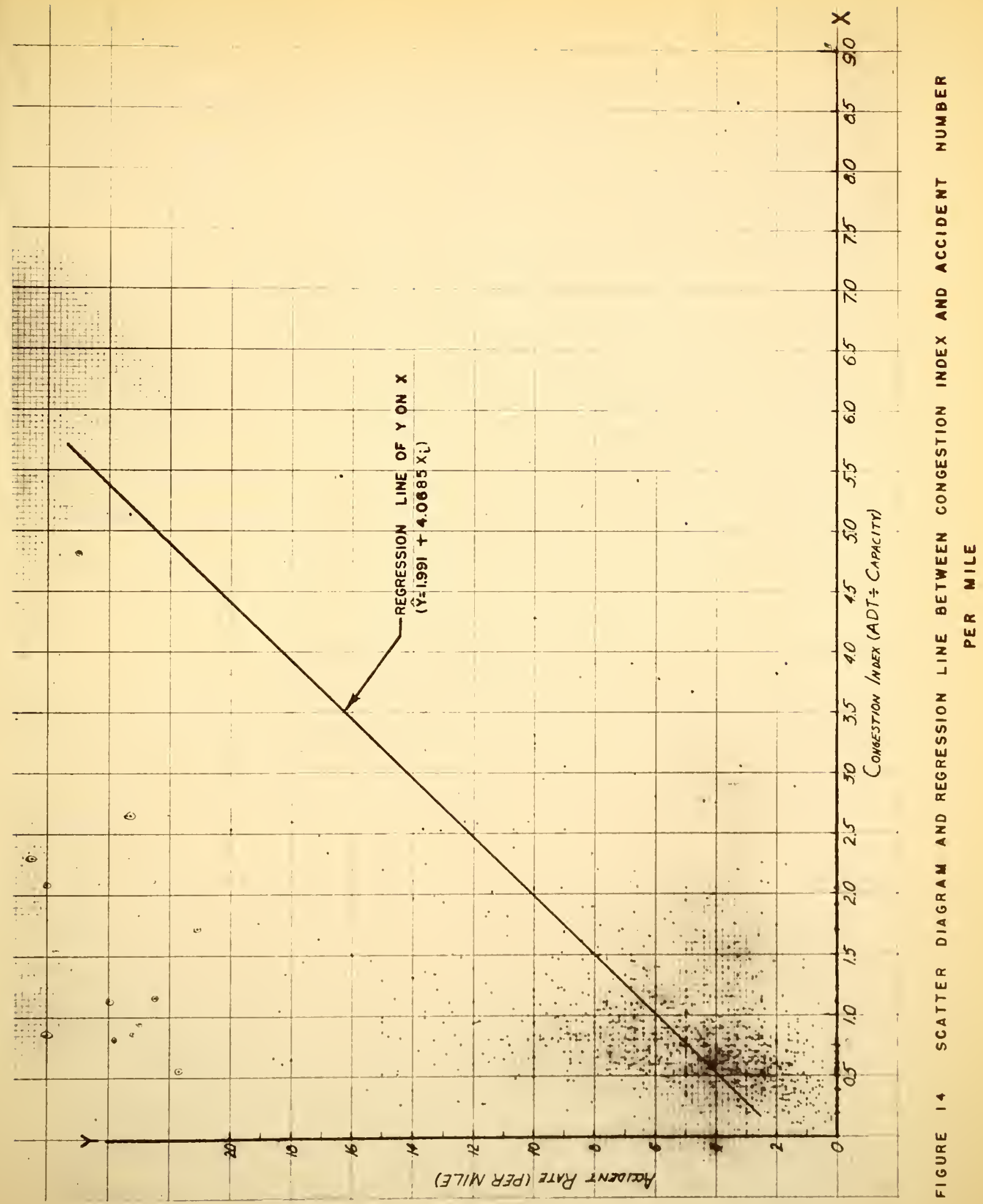




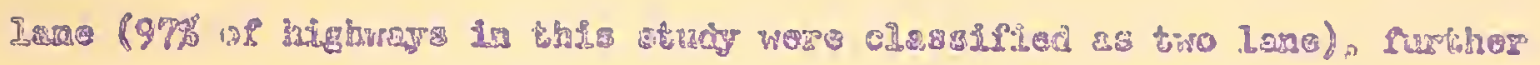

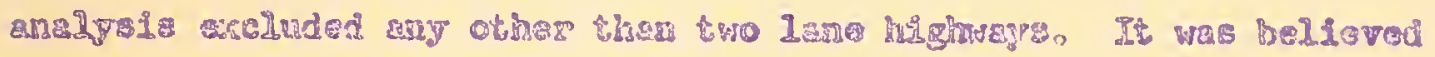

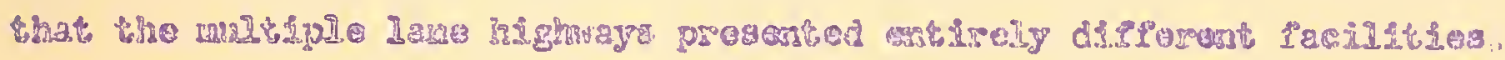

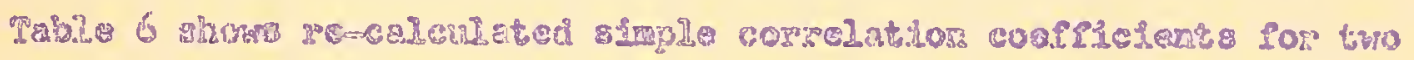

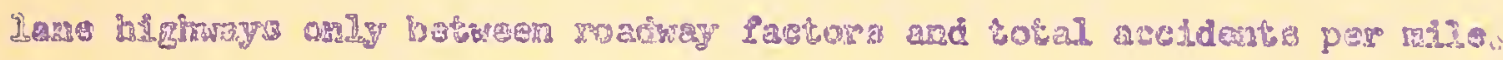

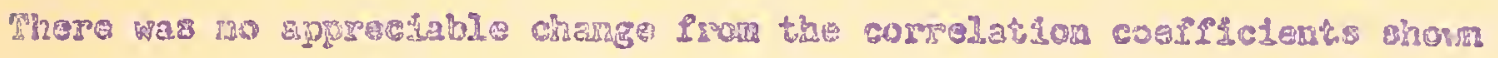

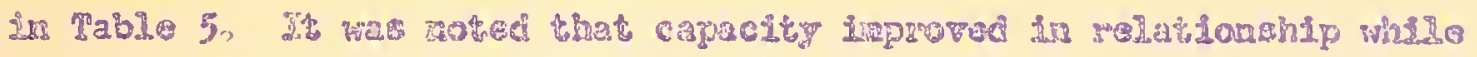

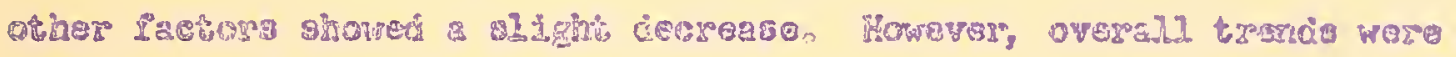

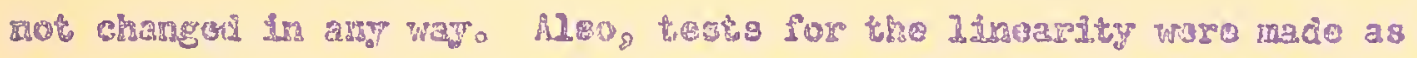

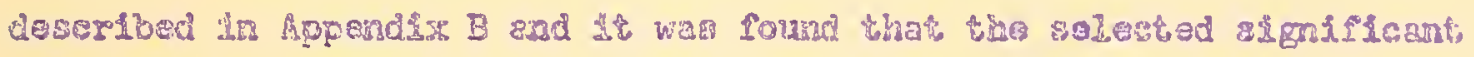

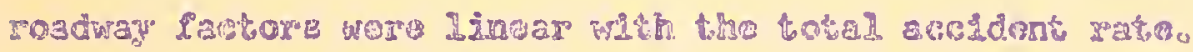

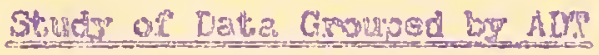

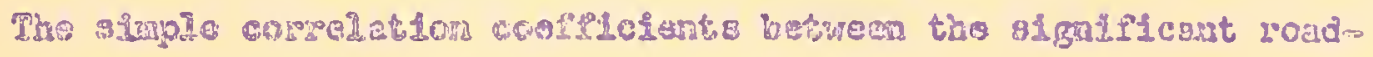

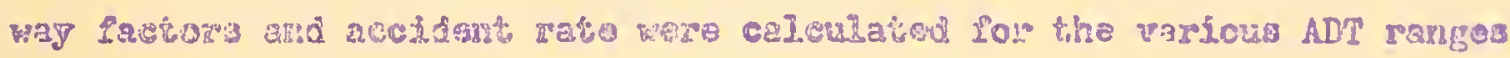

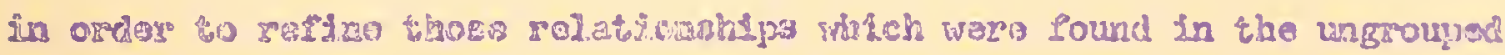
data。

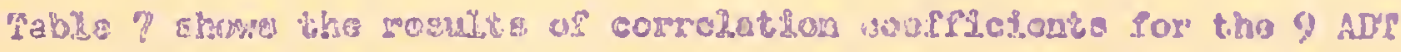

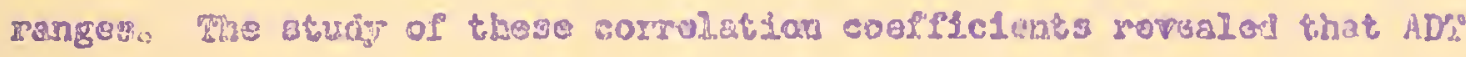
and extrances per will showed rot only positive worrelation whth totn: accident rate in ail ADI rangot but also they ghowsd tho savo trend in the variabulity of thas streagth. Thid anelysis indicates that the achident Decurreases were yost related to the ADS and total number of

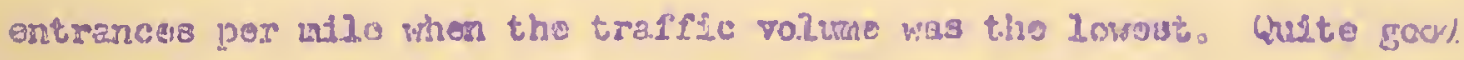

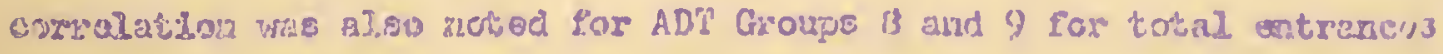


Tabie 6

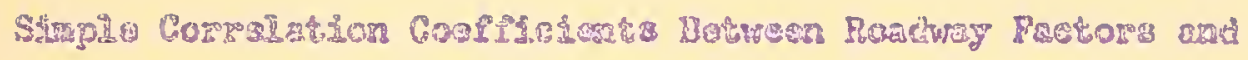

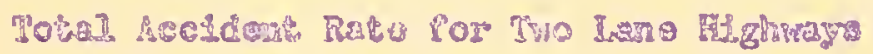

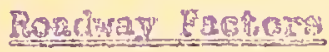

ATI

Gapacity

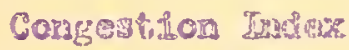

Jane Wider

Shondo Wes Wath

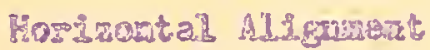

Entrances Fror His

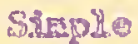 \\ Coresiatias \\ Coepriations}

0.425

$0 . I_{3} C O$

0.425

0. 18.48

0.012

$0.02 \%$

$0,25 / 4$ 
F⿻コ一⿻上丨

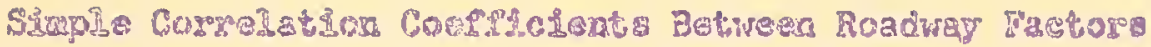

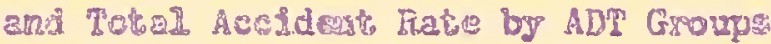

\begin{tabular}{|c|c|c|c|c|c|}
\hline ADr & $\begin{array}{l}\text { MDS } \\
\text { Manges } \\
\end{array}$ & $A\left[g^{\circ}\right.$ & Cougerstidor2 & $\begin{array}{l}\text { Xade } \\
\text { WIntus }\end{array}$ & $\begin{array}{l}\text { Antiondes } \\
\text { Pes IIIIO }\end{array}$ \\
\hline 3 & $0-98$ & 0.54 & 0.20 & 0,02 & 0.67 \\
\hline 2 & $1.000-2,938$ & 0.7 & 0.29 & Q. 4.4 & 0.06 \\
\hline 3 & $2,000=2,900$ & 0.99 & 0.28 & $=0$ n 0100 & 0.95 \\
\hline 为. & $3,000=3.990$ & 0.08 & 0.03 & 0.03 & 0.30 \\
\hline 5 & $40000 \cdots 5,998$ & $\mathrm{O}, \mathrm{int}$ & 0.00 & $=3,046$ & 0.02 \\
\hline 6 & $5.000=5,950$ & 0.036 & $0,0 \%$ & 0,05 & 0,05 \\
\hline ? & $6,000 \approx 6,909$ & 0.30 & $=0.03$ & $=0,19$ & 0.192 \\
\hline 8 & $7_{0}(0)=7,95 \%$ & $0 ., 5$ & $=0,04$ & 0.05 & 0.78 \\
\hline 8 & $E_{3}, 600$ ard atowo & 0.23 & 0.20 & 0.35 & 0,20 \\
\hline
\end{tabular}


pG:

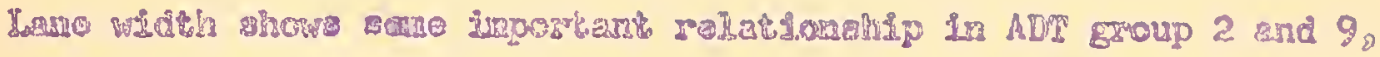

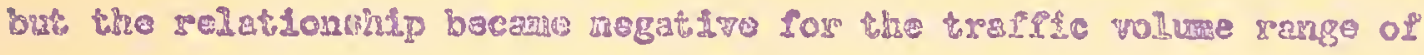

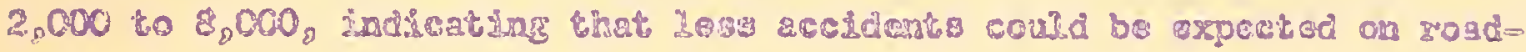

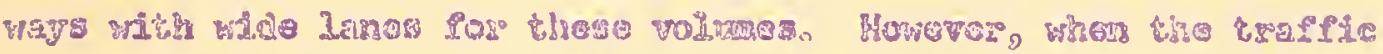

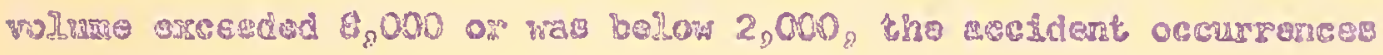

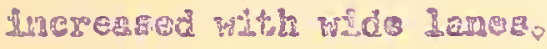

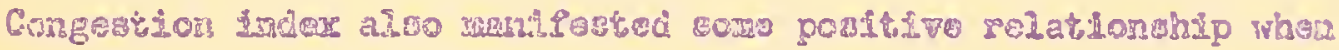

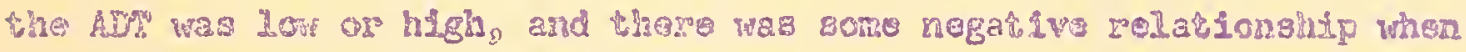

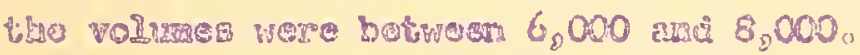

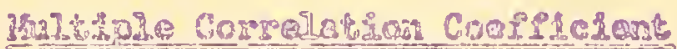

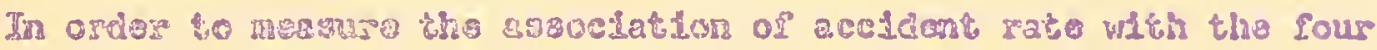

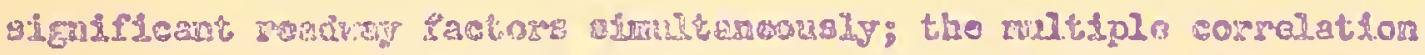

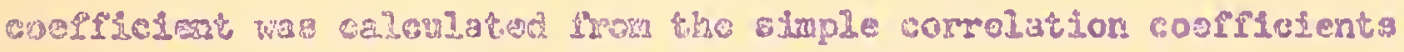
batwses malkay factors and acciciont rato thet are shom in tabio 78 and

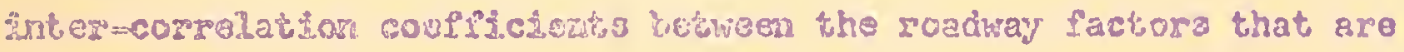
shewe In Palsh 8\%

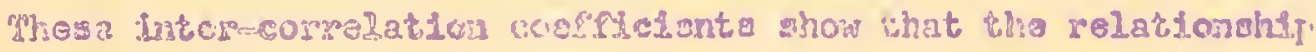

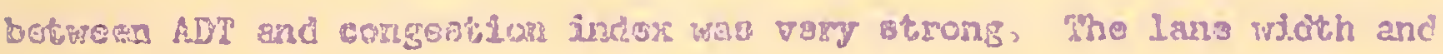

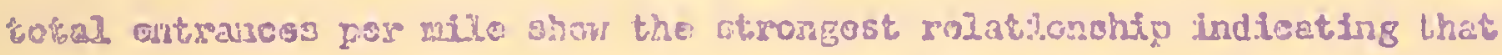
20 the lane whith was sacreased the total number of entrances also Inereabed proportionally. Kost cther relationshtpe denonolrated suno Bignificance although congestion hidex chowe very littlo rolationhilp with lane witho

By tiro method of Doolittls Solution" the multiole corrala'ilon 
Thases 8

Tht:

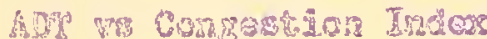

0,74

A

0.28

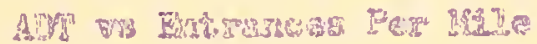

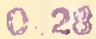

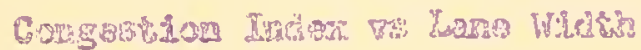

0.06

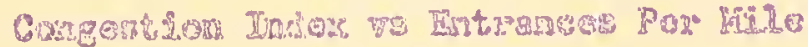

0,23

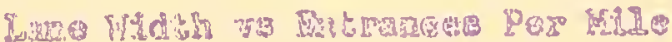

0,75 


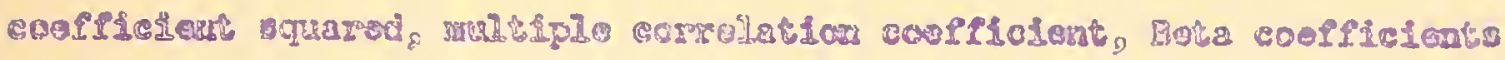

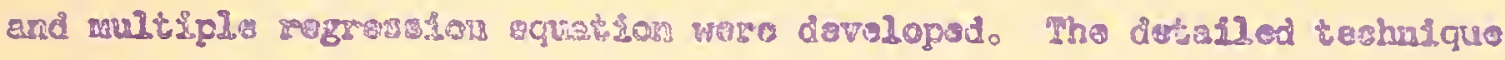

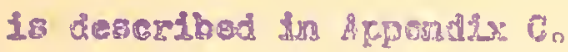

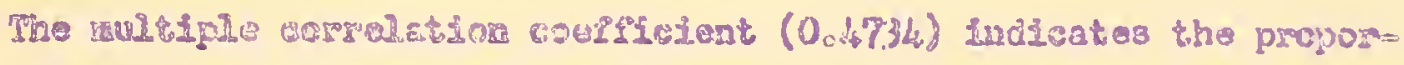

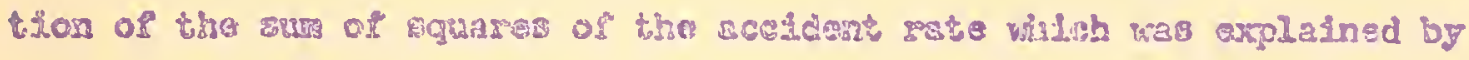

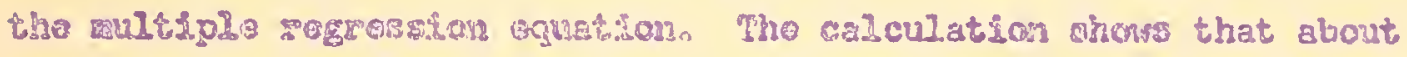

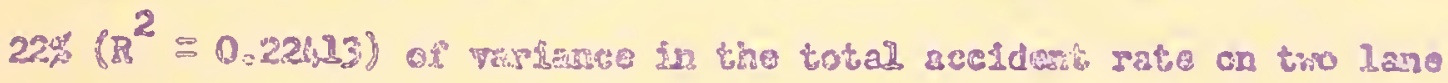

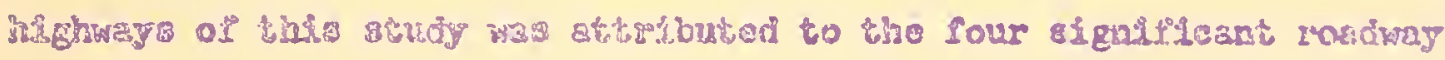
pactors?

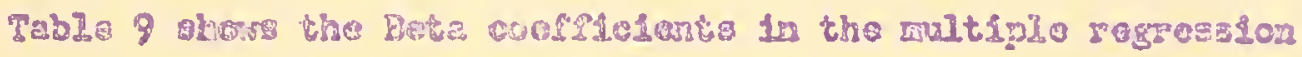

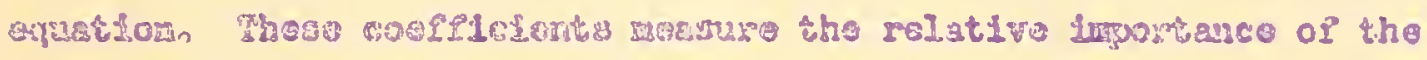

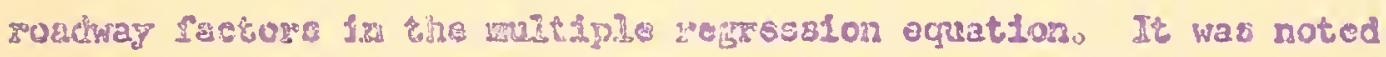
that the congesthan inder fileyoxi a mojor role in prodloting the number of Eccldents in this particuiar oquatoron

\section{Pareant, of: Irace in Prediction}

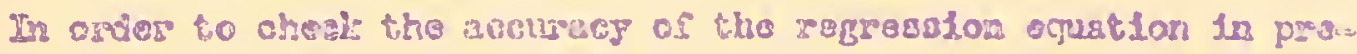
dieting the number of aceidents, tho asclecnt occumenen for 2953 and 2956 war depoyod agalnst the prodicted minss. phile tho lane with

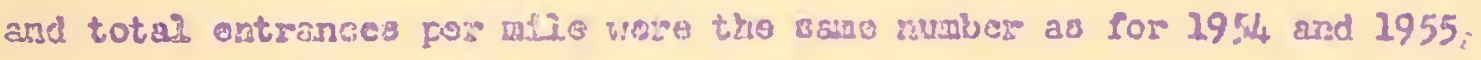
tho factos of tacrease irou 1953 to 1954 and 2955 to 1956 in trafle

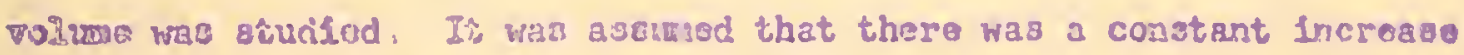
of trapfic volume Irem 1953 to $195 \dot{6}^{\circ}$. This 18 genorally correct fos Indiana. It was therefore asowsad that the total ADT and congestion 21. 20x of 1954 end 1955 would bo the same for the yoaro 1953 and 1956 , 
ga: 98

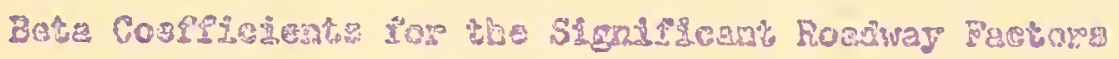

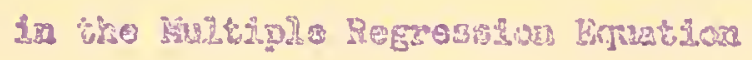

Roadwer, Pacrorg

ADT

Congantion Inder

Iane ride

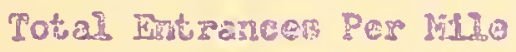

Lota CogPfigrans

0.879

0.302

0.283

$\Rightarrow 0,073$

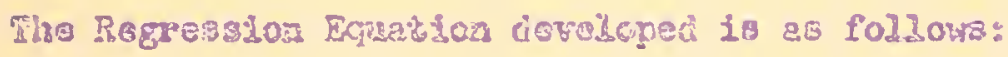

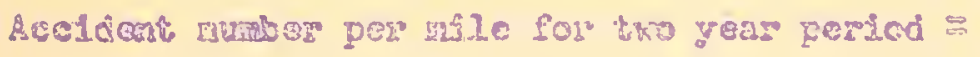

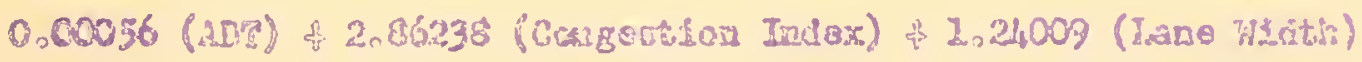

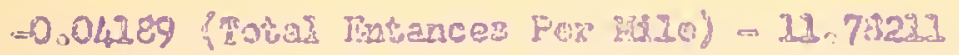




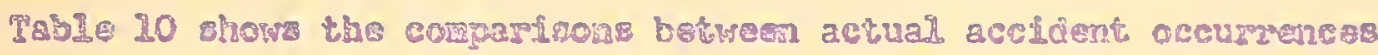

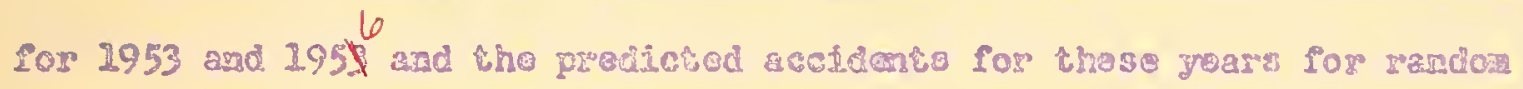

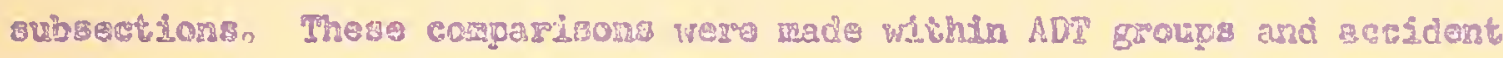

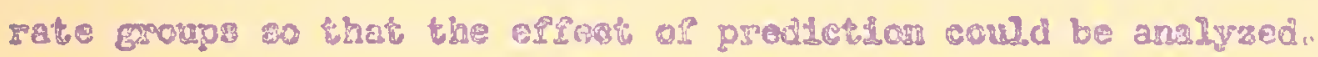

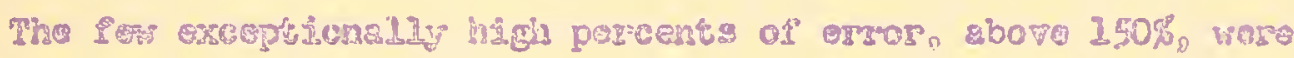

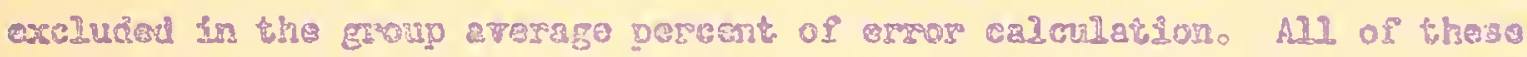

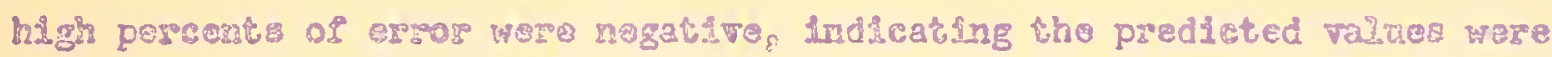
highes than the actual velues.

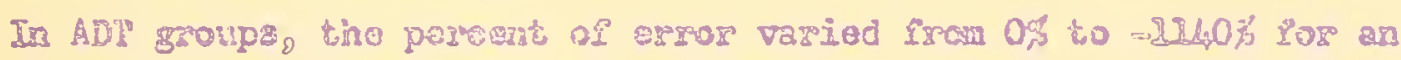

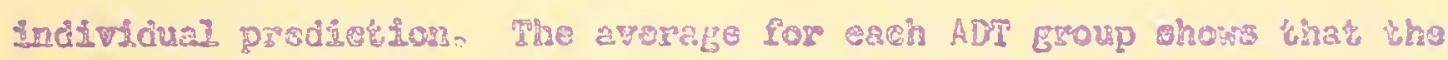

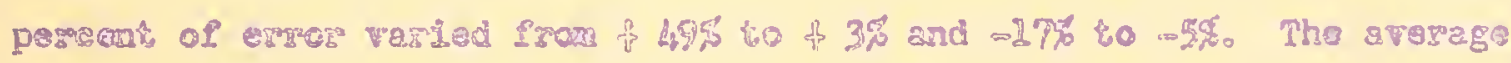

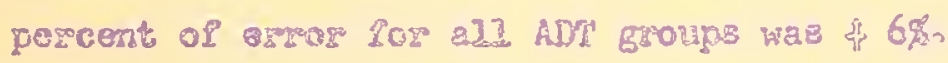

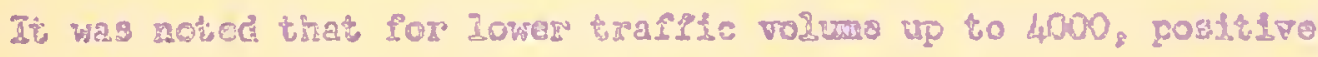

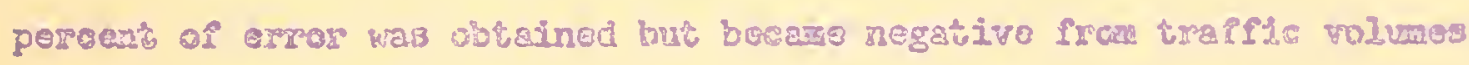
bestween 4000 and E000.

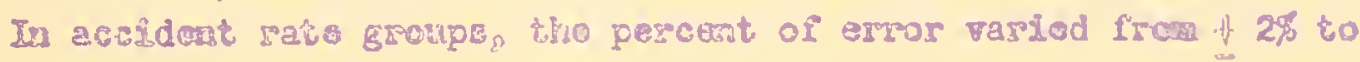

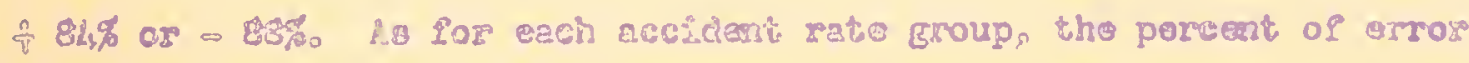

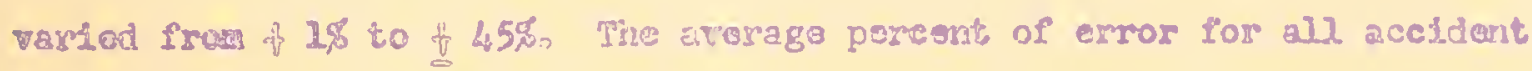

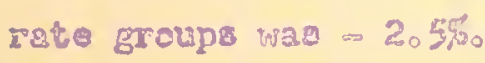

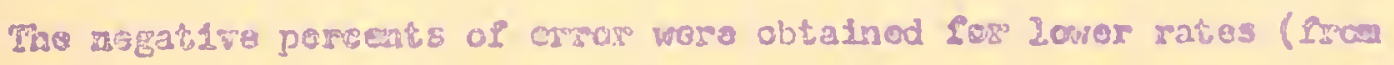
0 to 8), and the positive parcents of error oystenatically increased as tho accident rateg were increasol.

In gerseral, the percont of error increaod an tho traffic volume

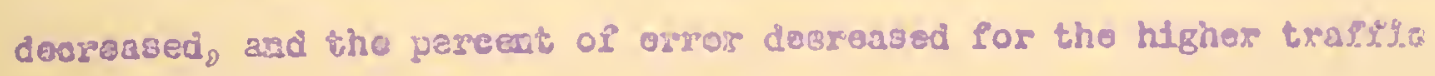
rอนบะ

The eccident rate group shcwo a rather irregilar tread? bowover, it, 


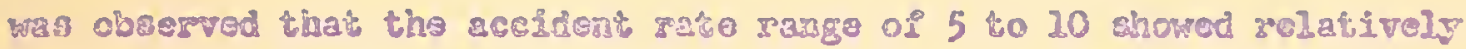

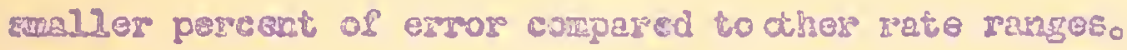




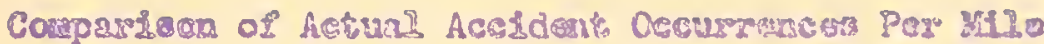

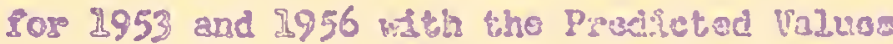

\section{A.. ADT Grousolng}

Group I $(0-1,999)$

2953 and 1956

Brodscted Taluse

Precent of Tyryor

$\begin{array}{lllll}2.5 & 1.3 & 3.8 & 0.4 & 1.9 \\ 0.12 & 0.05 & 1.2 & 2.2 & 3.2 \\ +100 & 792 & 263 & -45 & -6.8\end{array}$

Mterago

Pursogat

af Exrors

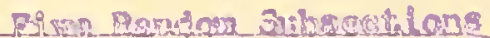

Grovp $2(2,000-2,999)$

1953 and 2956

Predictod Valuese

Porecas nis Lrror

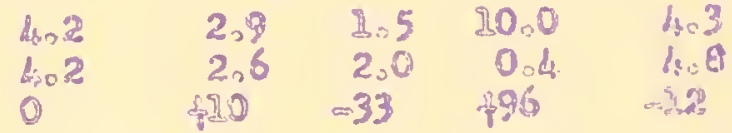

Grosp $3(3,000-3,999)$

\begin{tabular}{|c|}
\hline $\begin{array}{l}9953 \text { Ead } 2956 \\
\text { ProdLerod Vadues }\end{array}$ \\
\hline
\end{tabular}

Group $4(4,000=4,999)$

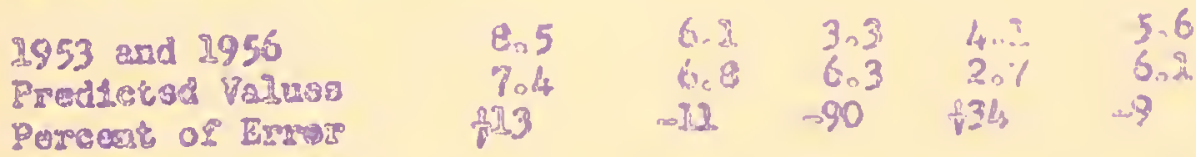

Croup $5(5,000-5,999)$

\begin{tabular}{|c|c|c|c|c|}
\hline 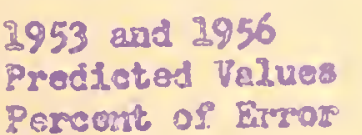 & $\begin{array}{l}5,9 \\
7.4 \\
-25\end{array}$ & $\begin{array}{l}5.0 \\
8.2 \\
-6:\end{array}$ & $\begin{array}{r}3.0 \\
3.6 \\
-72\end{array}$ & $\begin{array}{r}30,0) \\
7,5 \\
+75\end{array}$ \\
\hline
\end{tabular}

Group $6(6,000-6,999)$

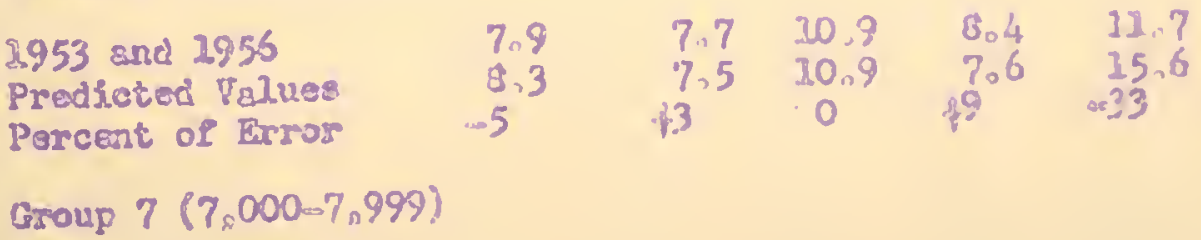


2953 asd 1956

Predleted Values

Porcent of Estros
6,3

8,9

4 ?
6.9 6.9
10,2

6.7 $-48 \quad 69$

$-69$
22., 1

8.1 $\$ 33$

Group \& (8,000 and abota)

2953 ard 1956

Predicteri Values

Percent of Esrar

\section{5 \\ 24.8 \\ $(-3)$}

\section{2.} 30.36 .7 (-13:0) +2
15,2

27.2 $-12$

Acchose Rate Gromplng

Group \& $(0=1,9)$

1953 acci 2956

Preâleted Talues

Fereant of Exrots

Group $2(2=2,9)$

2953 cind 9850

Predicted Vivos

Porsert of Errizar

Group $3(3-3,9)$

2953 and 9956

Predictod Paduss

Percest of thror

Group \& $(k=4.9)$

2953 and 2956

Predicted Vaires

Percori of Erro:

Group $5(5-5,9)$

2953 and 2956

Predicted Valuoa

Percent of Error

Group $6(6-7.9)$

2953 and 295 ?

Predicted Va?ues

Percent of Elror
3.5

6.8

2.6

0,4

2.9

$\begin{array}{llll}24,8 & 3.8 & 2.9 & 0.9\end{array}$

$\begin{array}{lll}(-287) \quad \text { - } 744 & -27 & -125\end{array}$

$-22$

8.8

11,4

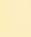

\section{年}


Grous $7(3-9,9)$

$\$ 953$ and 2956

Predicted Palue:

Parcest of Errots

Group \& $(10=93.9)$

3959 and 1956

Predicted Faluos

Percent or reros

Grous 9 (us and arovo)

2.953 228d 1956

Prodided Palus

Parcent of Ihrsor

\begin{tabular}{|c|c|c|c|c|}
\hline $\begin{array}{l}2.5 \\
6.8 \\
(=172)\end{array}$ & $\begin{array}{l}2.5 \\
4.4 \\
=95\end{array}$ & $\begin{array}{l}9.6 \\
5.8 \\
140\end{array}$ & $\begin{array}{c}21,2 \\
1.3 \\
\frac{2}{3} 83\end{array}$ & $\begin{array}{l}8 ., 4 \\
8,9 \\
-6\end{array}$ \\
\hline
\end{tabular}

$\begin{array}{lllll}6.4 & 5.6 & 9.9 & 3.9 & 9.1 \\ 21.2 & 6.9 & 5.7 & 4.4 & 3.5 \\ 8.231) & -23 & 142 & 42 & 1.52\end{array}$

$\frac{8}{1} 20$

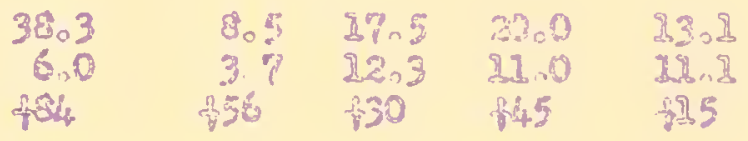

$+4.6$

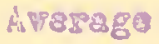

$=2.55$ 


\section{SURMARI OF RESULTS AFD COMCLUSTOUS}

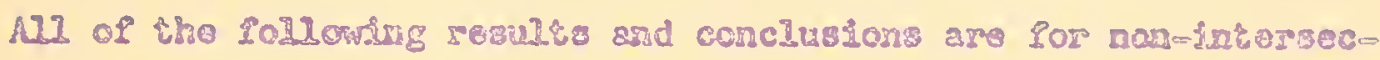
thonal acciderta om the tro-1ass Indana Rural Stato Primary Systen of Kiปglaw? 8:

\section{Sturnarger of Revults}

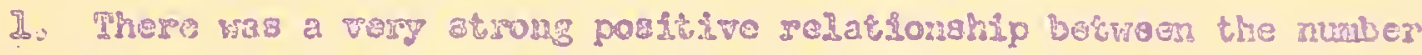
of ecciderts P02 1954 and 3955 on the Eare sutsaction, thus conf1rwing the the ory of बrpozura $(12)$.

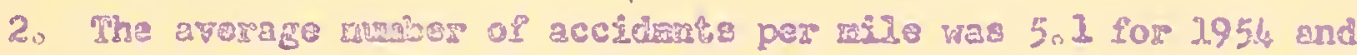
1955. The hightye with aceidert reter below this averego comprised To\% of the fotal gyster. Tho ratio of nornofatal to ratel accidents was 42 to 1 .

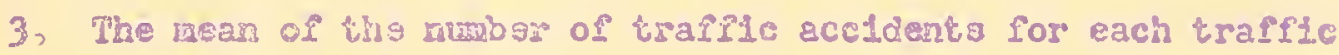

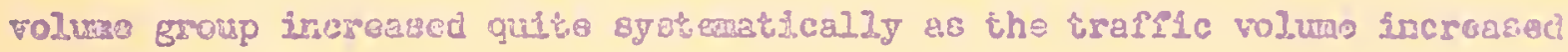
by an increment of 2000 variclsz psr day.

40 The ranga of traffle rolumse Irom 2000 to 5000 included moro than one salf of tho totel accldeats and cas half of the total miloace.

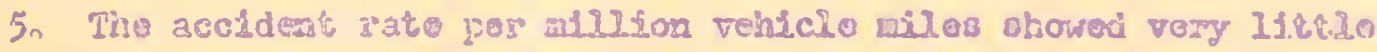
relatlonship with rosdway fectos?. The sccident rate per mllo showed a ranonablo ralotionship and this rate wa ubed in tho dotailed analys13 of this arudy,

6. Four roadway factors ware found to poosoes quite good J.Inesalty 1. Ith accident rate; thoy wero annual avorago dally traffic (ADT) cor: 


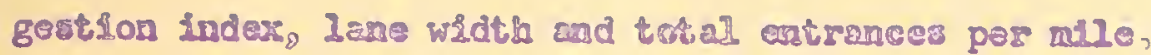

7. Three posdway factors were found to posecs 21ttlo corrolation with accident rate In this otudy they woro eapacity ahoud watho and horizontel allgront.

8. ADT and total nuber of mirances per nilo showed a positivo correlatlon with accidont rate in all ADT groups, and thoy follored \&

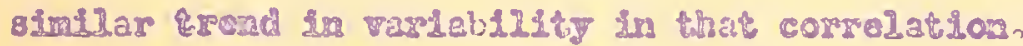

9. ADS and rotal mubor of ontrances par rello were vory highty correlated will accldent rato 1 ra roadi with t5atric voluser of 2000 os IEse, and oxhlbitod vorg good condation cr roads with ADs rolumeo abore 8000

10. Among tho four eleniflesat roadway fectors, there was a stroag

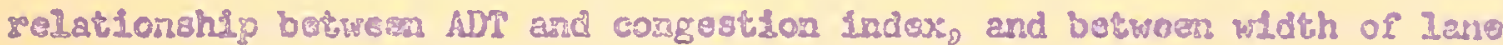
and total muber of antrances por inllo.

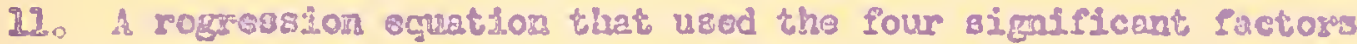
to pradiet ascideat salo per mllo was doveloped and was found to bo:

Accident rato pei milo for two yearo - 0,00056 (ADT) \& 2.86238 (Congestion Index) if 1,24009 (Lave Widih) - 0.04l89 (Total Entrances pos Kile) - 21.78221

12. Tho relativg atreagth of" the four sasdway factors in tho rag= rossion oquatson was, in ordar of atrength; cangostion index, lano width. ADr and total murber of entrancos por nilo, Congostion inder exhibitod a major rols in the above rogression equation.

13. Whor the eccident rates for 1953 and 1956 wore prodicted frat

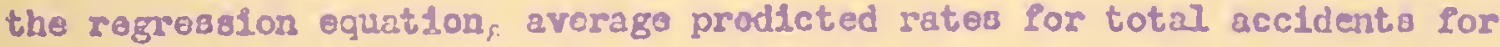
the system as wall as for ADT groups ahowed only a sall percant of orrose 


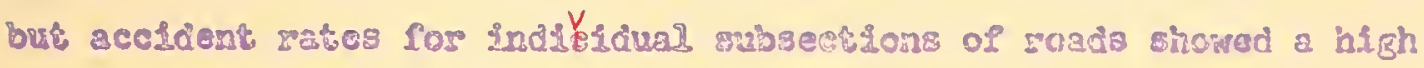
yardabl11t5.

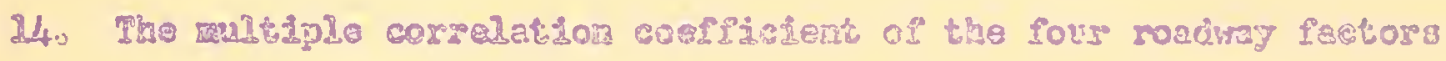

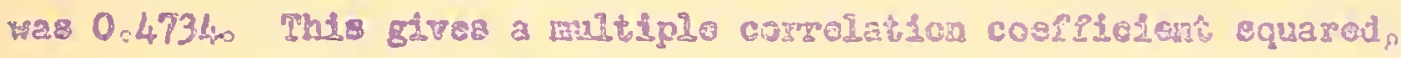

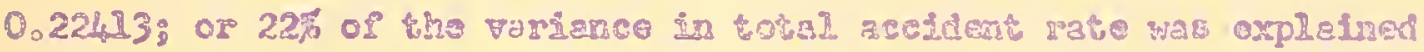
by the regresgion expetzen.

\section{Corclez:ore}

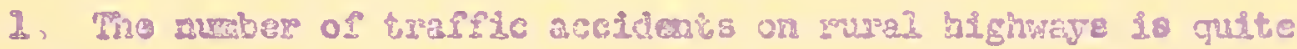
atronghy related Insarly to trafilc Folure and congested condithon.

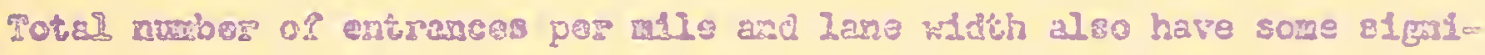
ficant Iinear relatsonghp,

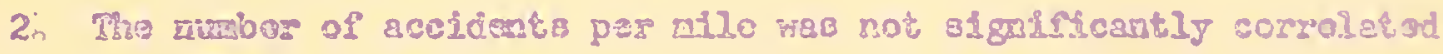
With capacty, shouldor wldth or borlzantal allgrent as thoy were opac luated in this study.

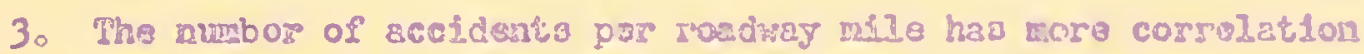
with roscuay factorg than tho matos of accidant per vohlcle whe

4n Appiarimately $22 \%$ of tho vardarce in totad rcoldent rato was explained by the joint offect of the four slgniffcart roactury factors; and $78 \%$ of the variance in tolal acclaieat pate was attributed th the ochar cauasain

5. The dominant effect of traffic volume and the close relationsip botwoen 1954 and 1955 accident occurrencos on tho sene hichways conftrw the theory of axposuro in accident occurronce. Thus the anount of hazard exposed on tho two lano rural highwags which do col 10rolvo 


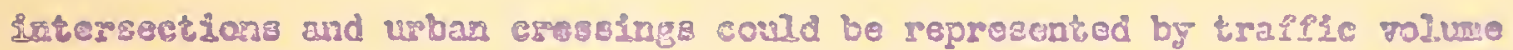
and wilesgo of the highwayso 
ETEUT TOGRAPET 


\section{RIEIJOGRAPKE}

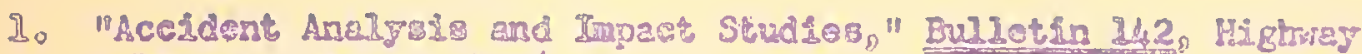
Rasoareh Board, 1956。

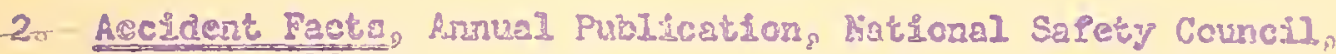
Chiceso, 2955.

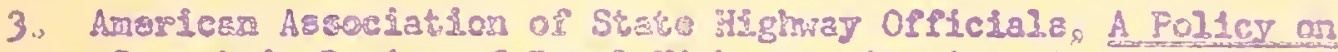

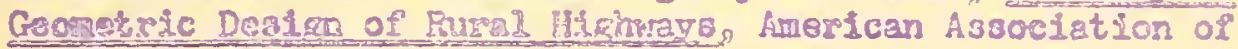
Stato Mighway OfPlC dels, 1955 .

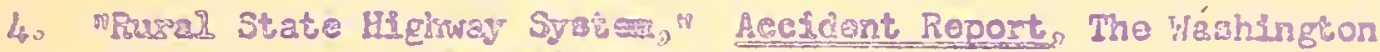
State Highway Comnission, 1955。

5. Belmont, Do Ho "WePlet of Siroulder Hidth on Accidente on Twa

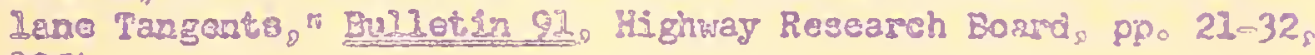
2954。

6. Berry, DoS, and Gres!, $F_{0} H_{0}$ Adequate Hichmars are Safer Migho

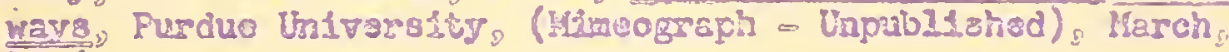
2956 。

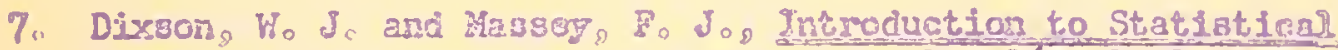

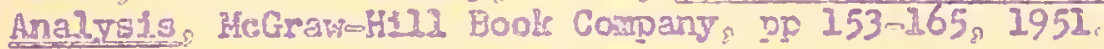

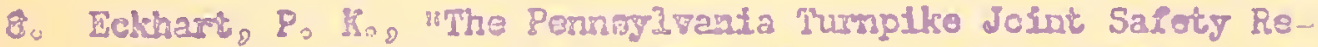
searchi Projoct" 2933 Proceodinge 24 th Annual Moating. Institute of Trafic Engineoring, $\mathrm{Pp}, 74=78_{6}$ Octobor

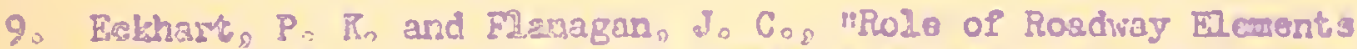

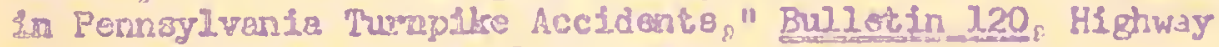
Rezzarch Borst, pt 213-133, 1950.

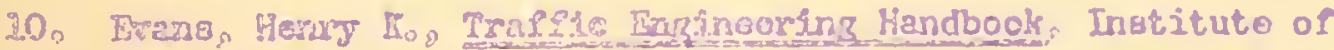
Trarfic Engineores, pp. $113-133$, 1950

11. Hof Tan, $P, G$, HAghay Safoty, SAE Boccraft hemorlal Lecture, 1947.

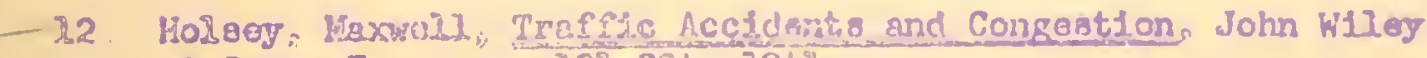
\& Sons. Inc $\mathrm{pr}: 123-294$. $194 \mathrm{t}$

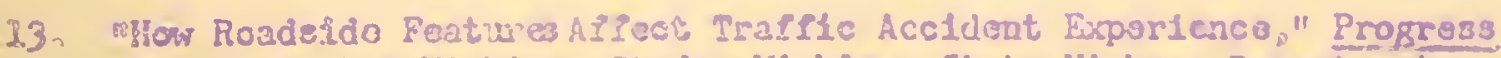

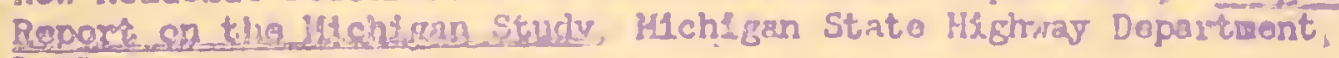
2951. 
14. Iorgansen, $R_{0} G_{0}$ and Hitghal, $R_{0}$ Ho "Accident Analyals for Program

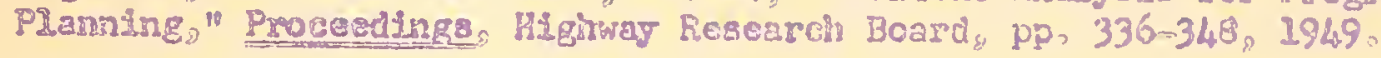

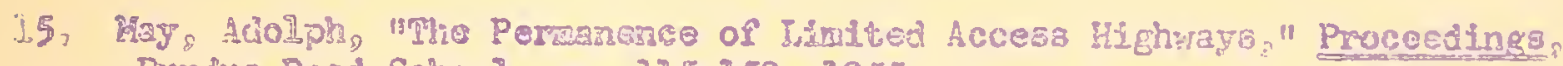
Furdu Road Selsool, ppo 115-150, 1955,

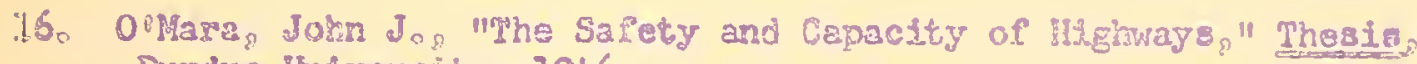

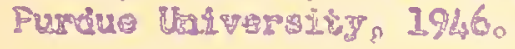

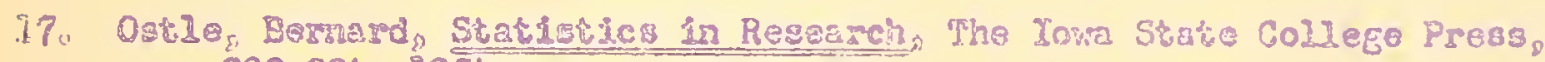
ppo $202=224,295 \%$

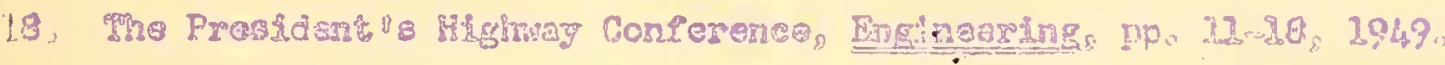

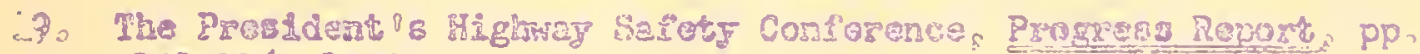
$201-126,1950$.

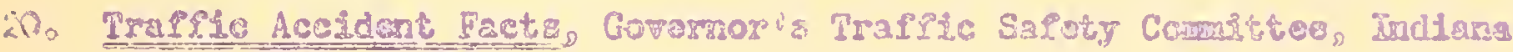
States 295492950

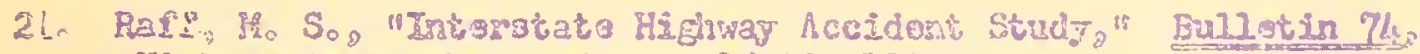

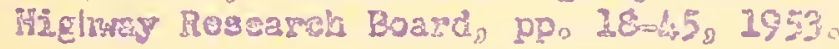

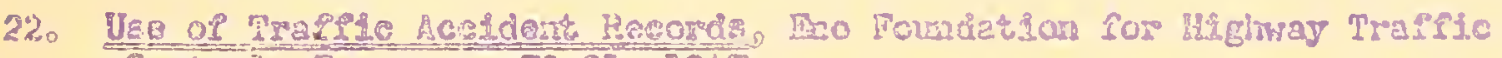
Coritol, Incos 290 73-93.8 294?

2?. Webb, G. Wog "Tho Relarson Botwean Accidents and Trapile Polumes at

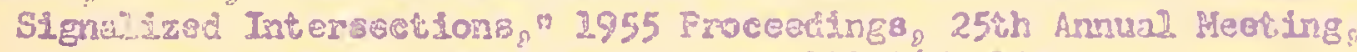
Institute of Traffic Englnsoring, ppo 149-167, 1955.

i4. Wobbr G. Hog "Use of Acosdent Rocorcis in HLghway Planning and Deslgn,"

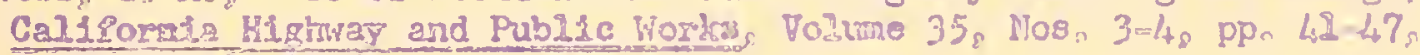
MarchsoAprol1, $1955^{\circ}$

25. "Stativtical Analjgir of Highway Accident8" Bulletin 17] Highway Besearein Boart, 3956 . 
APSISOIX 
APPENDIX A

GELCULATIOD OF STHPLE CORPHLATION

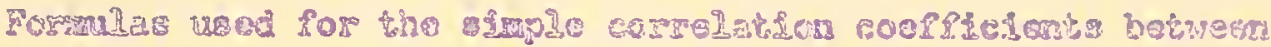

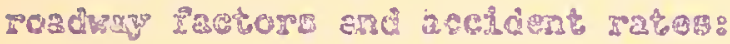

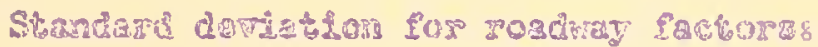

$$
S x+\sqrt{\frac{D x^{2}-(K x)^{2}}{N(N-i)}}
$$

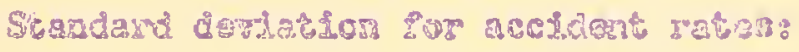

$$
5 \sqrt{\frac{M E H^{2}-(3-1)^{2}}{N(H-I)}}
$$

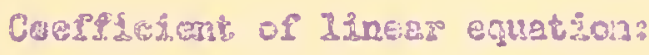

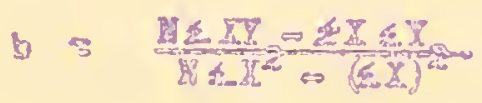

Simp20 cerre\}.ation coofflelon;:

$$
\text { zo } \Rightarrow \text { b } S_{y}
$$




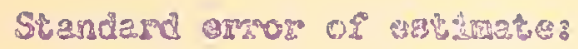

$$
g_{y \circ x}=\sqrt{\frac{11=1}{45-2}\left(S_{y^{2}}^{2}-b^{2} S_{x}^{2}\right)}
$$

Is

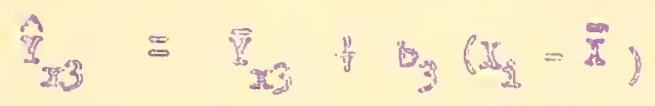

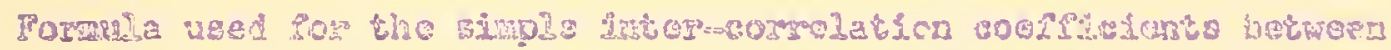
moacivey fectos.

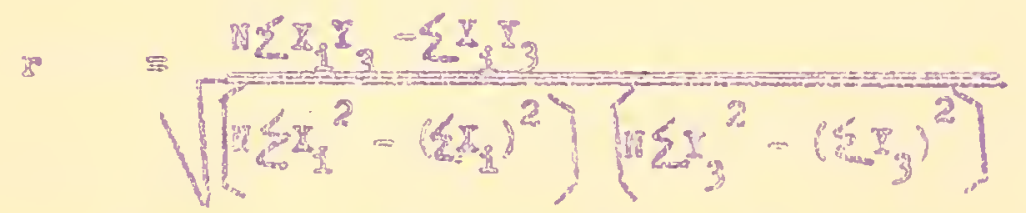

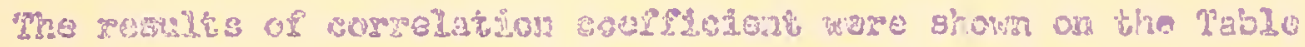
5. $6_{8} \eta_{0}$ and $e_{3}$

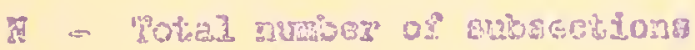

$$
\begin{aligned}
& x_{1}=\text { Rcadrag Ragtora: }
\end{aligned}
$$

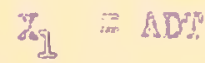

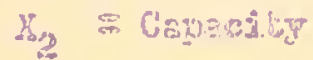

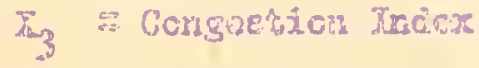

$$
\begin{aligned}
& x_{4} \text { a fiveloer or tansto } \\
& x_{5}=\text { Lars wiftis } \\
& y_{6}=\text { shourcer wath }
\end{aligned}
$$

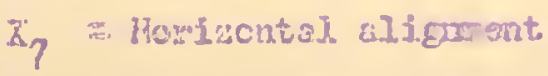

$$
\begin{aligned}
& x_{g}=\text { Toc2i numbor col entrances per riblo }
\end{aligned}
$$




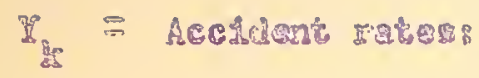

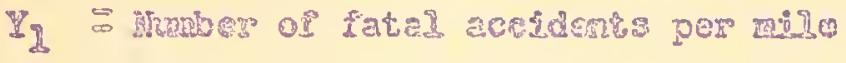

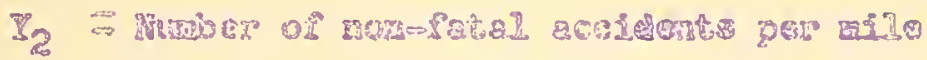

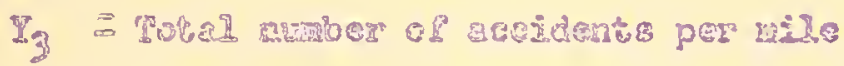

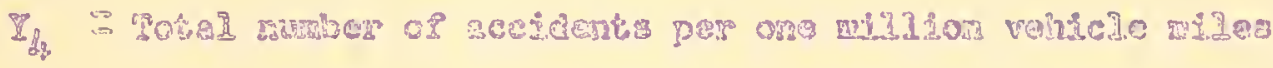

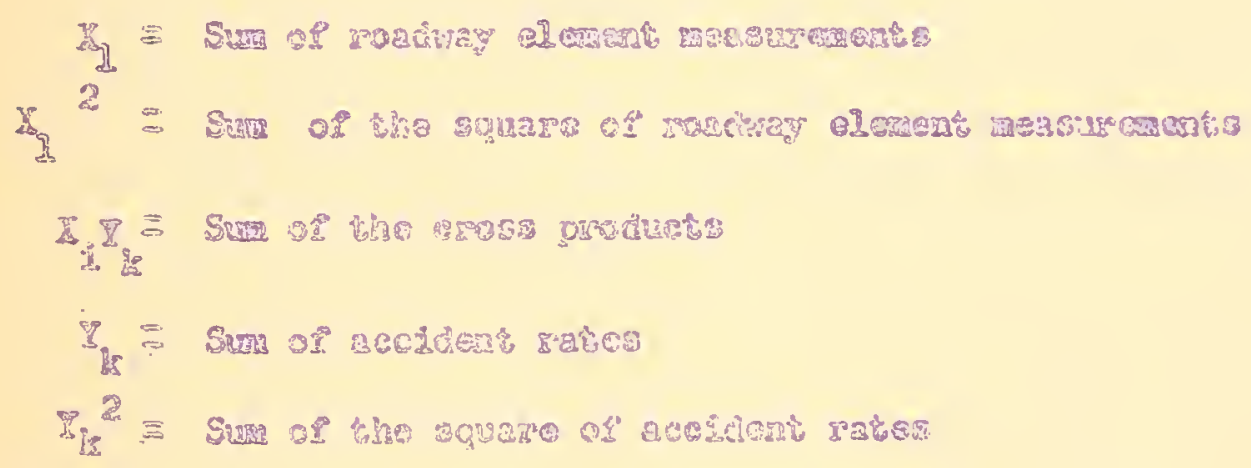


SPPEHDIX

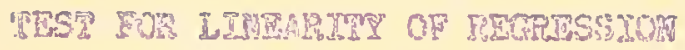

The he 2

B.4工

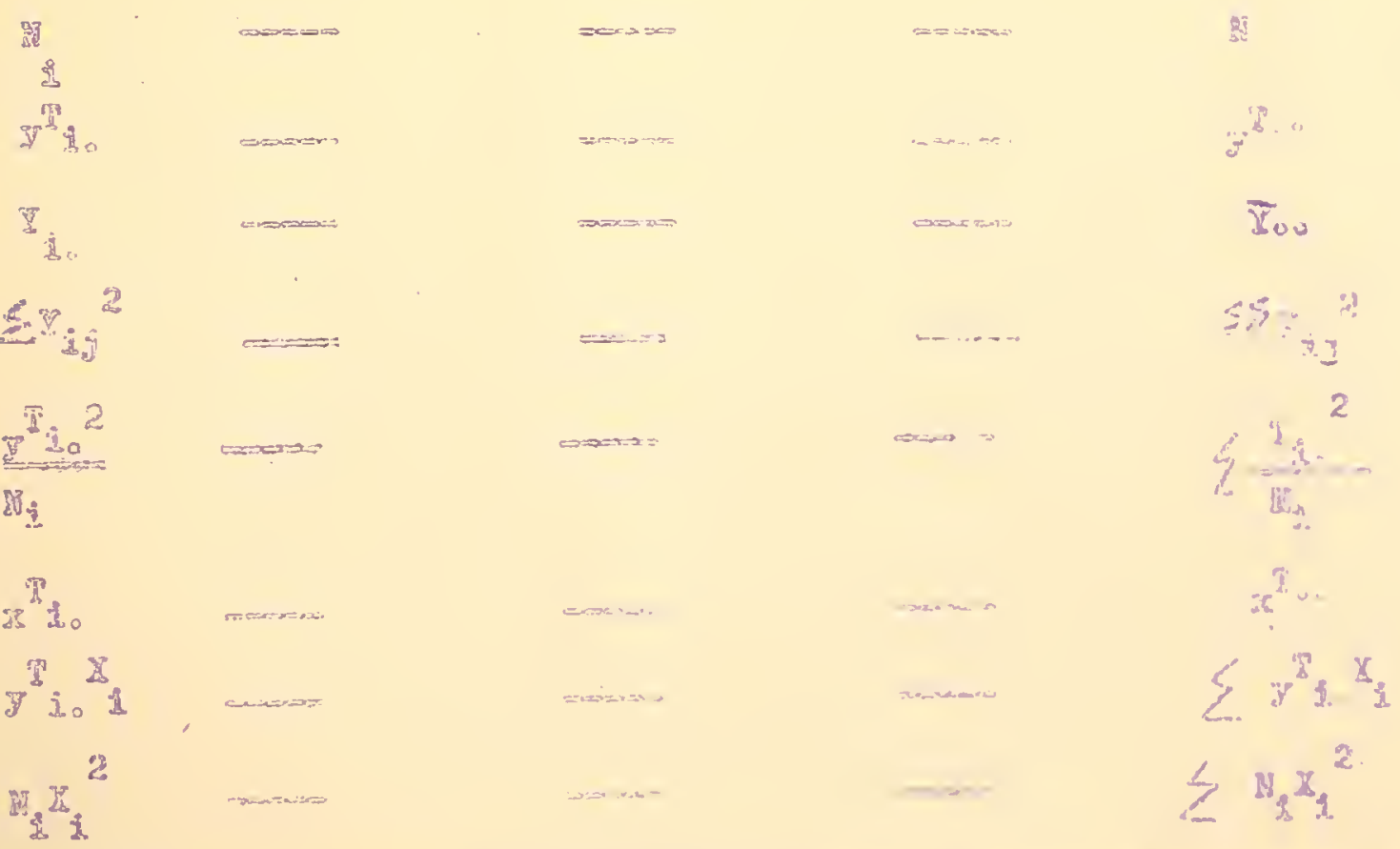




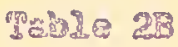

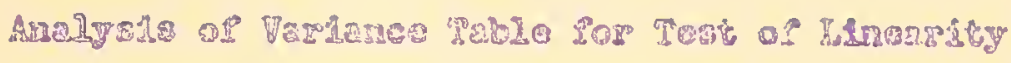

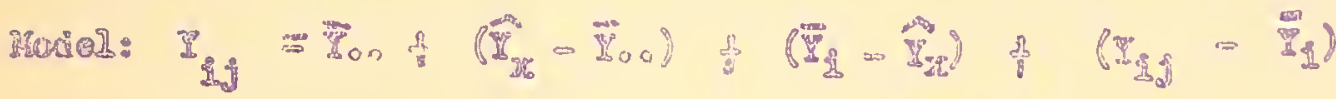

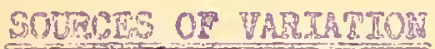

Araong Group:

Dhe to In

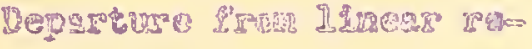

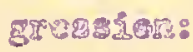

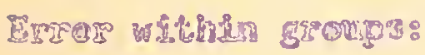

Tots
DEGAR OF FREEDOAZ SUIS OR SCIARES SCIJAOES

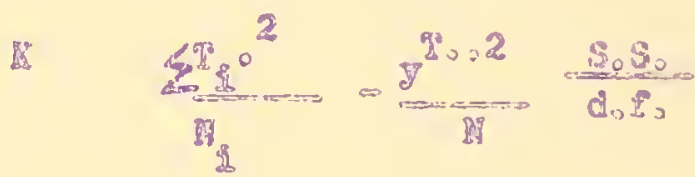

2. $\quad 50(x)^{2}$ $(x)$

F $\Leftrightarrow$ I D D

$\mathbb{M}=\mathbb{1}-\mathrm{I}$ Wifference

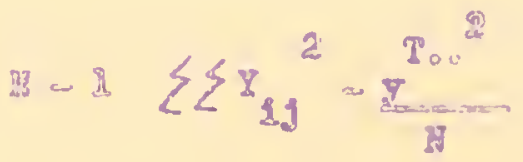




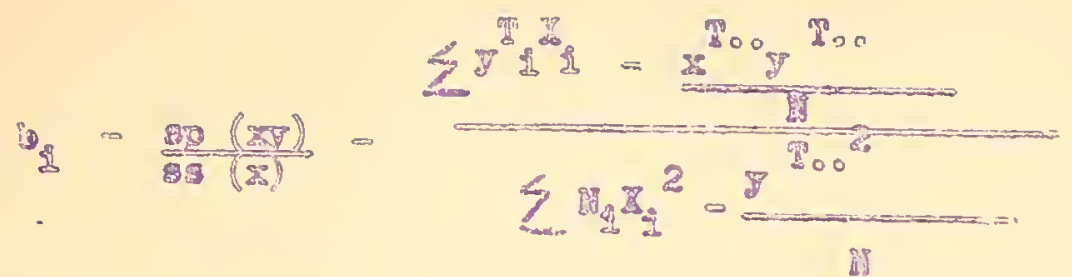

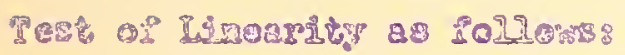

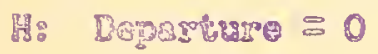

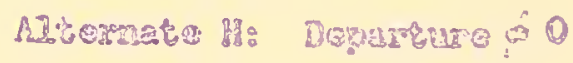

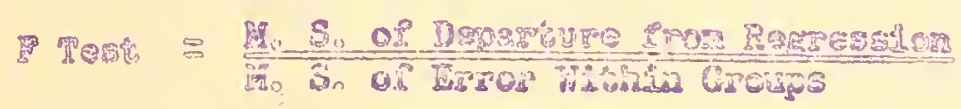

$\eta^{2}$ (1)

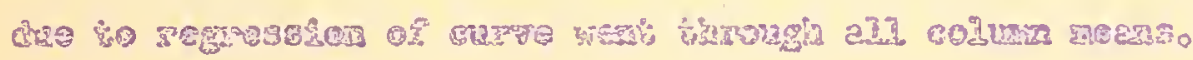

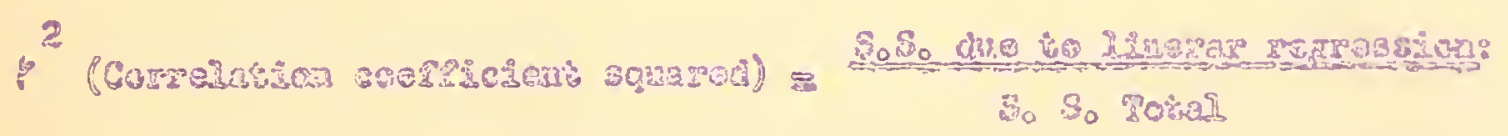

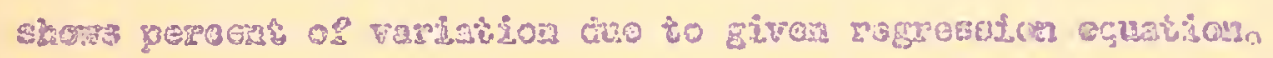

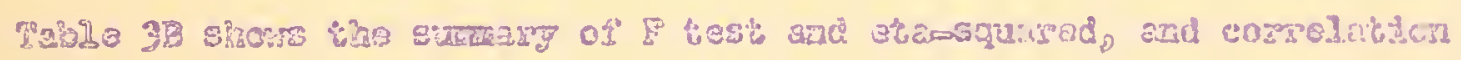

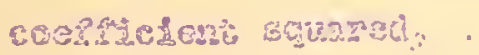




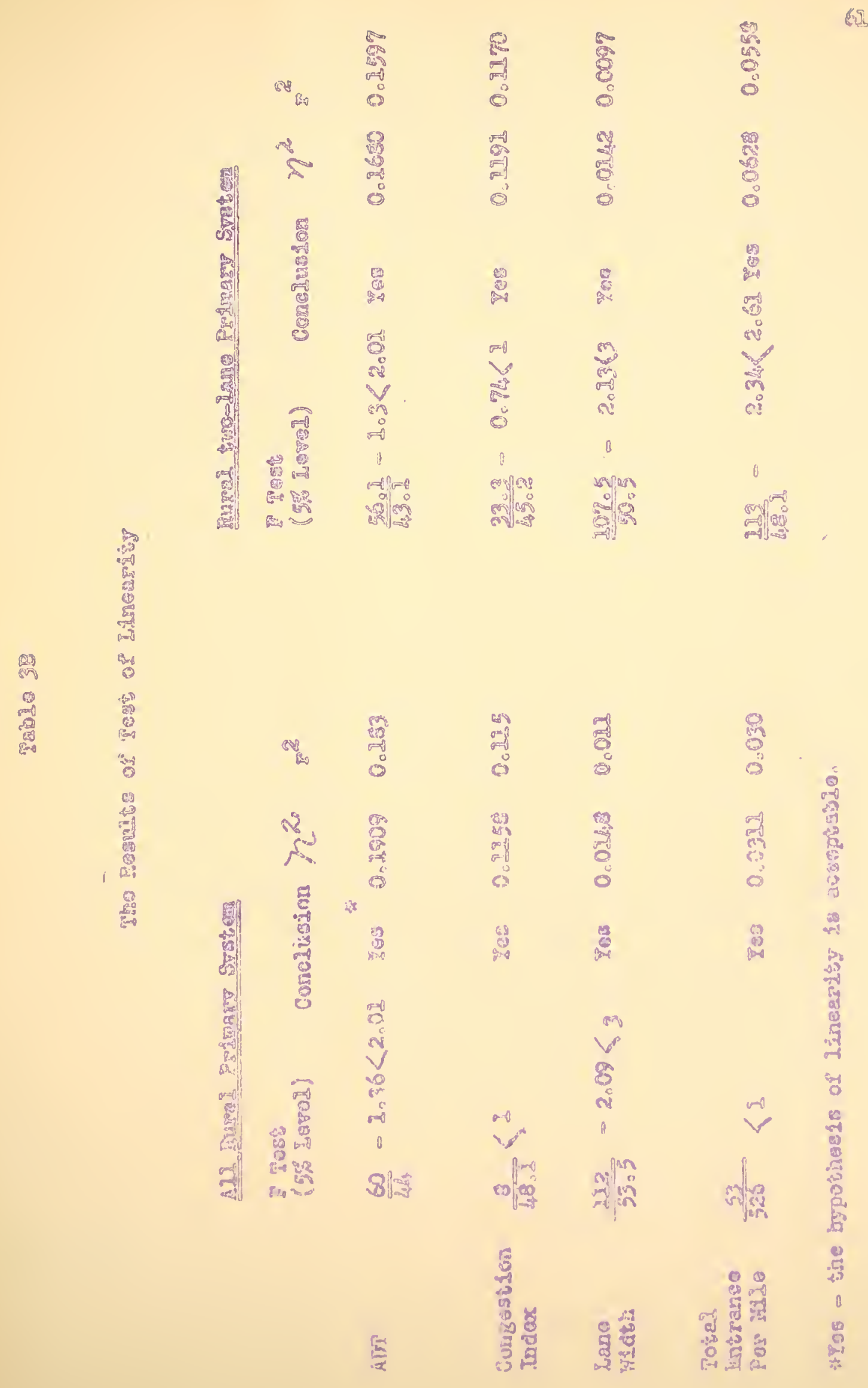




\section{APPESOIT}

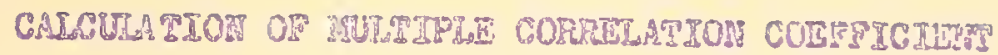

Tabio 26

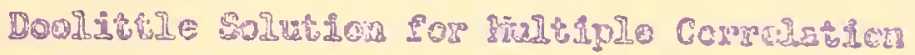

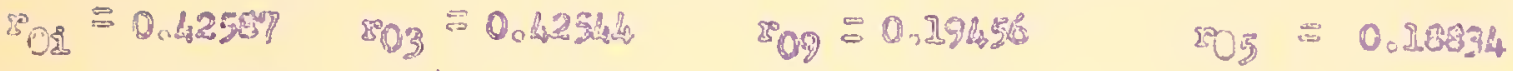

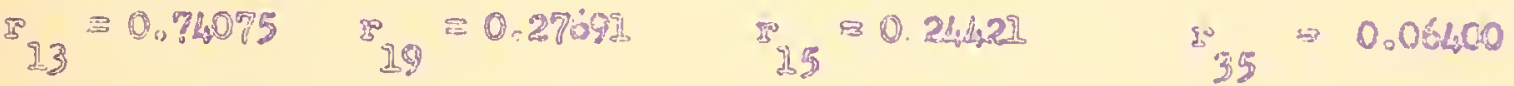

$$
\begin{aligned}
& 28=0.27503 \quad 500.74949
\end{aligned}
$$

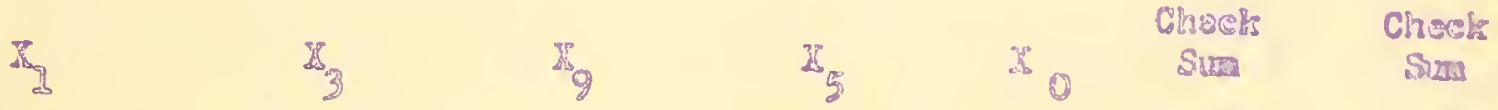

\begin{tabular}{|c|c|c|c|c|c|}
\hline 政 10,0000 & 0.74075 & 0.207892 & 0.24427 & 0.425807 & 2,65774 \\
\hline$x$ & 200000 & Do27503 & 0.06400 & Oolnogiss & 2,50522 \\
\hline & & I. 000000 & 0.749428 & 0.89456 & $\lambda_{0} 49592$ \\
\hline$x^{2}$ & & & 1.00000 & 0.888344 & 2021.596 \\
\hline
\end{tabular}

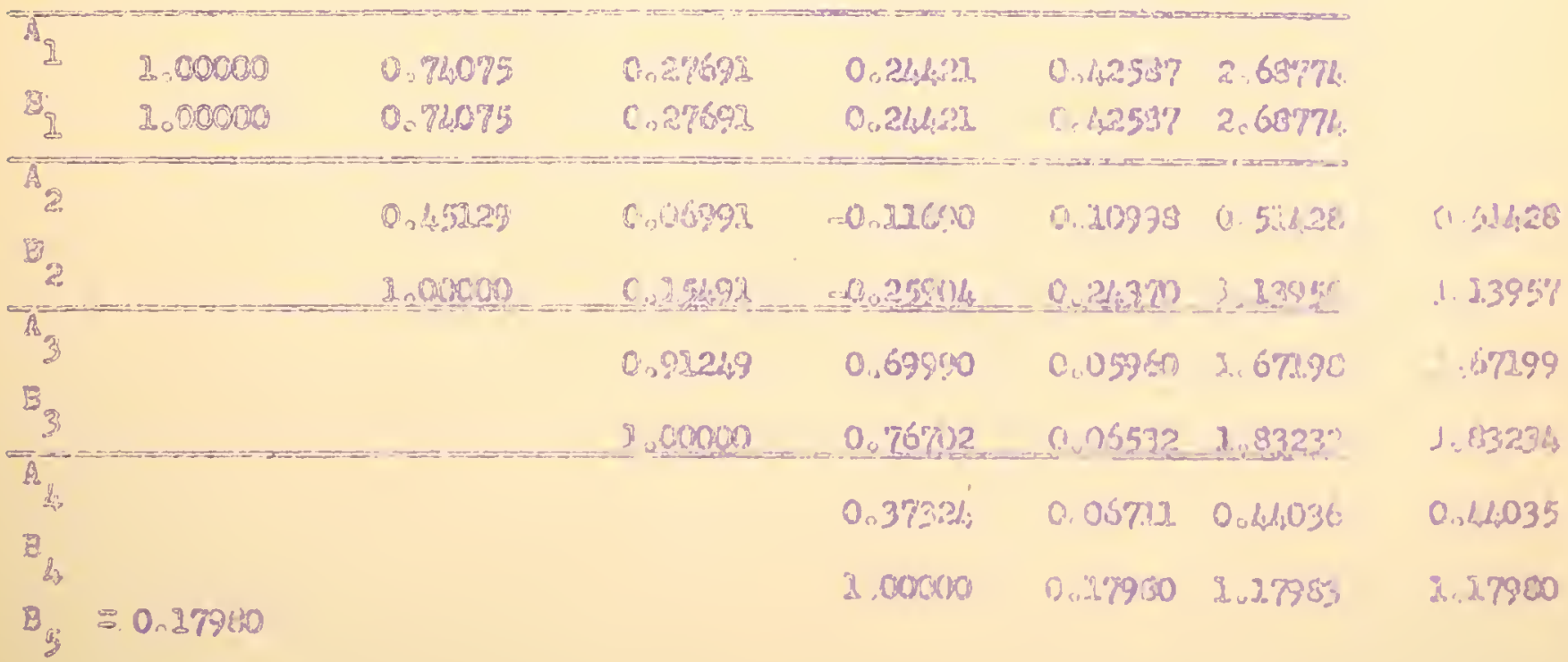


$B_{9}=0.06532-0.76702(0.9795 \%=0.07459$

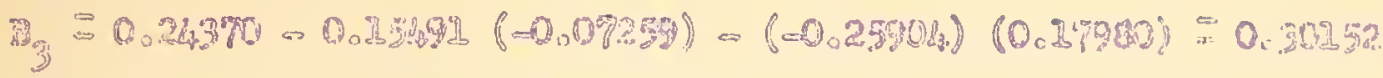

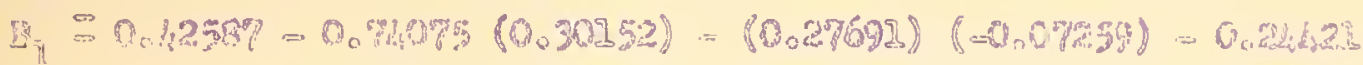

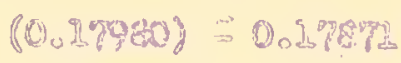

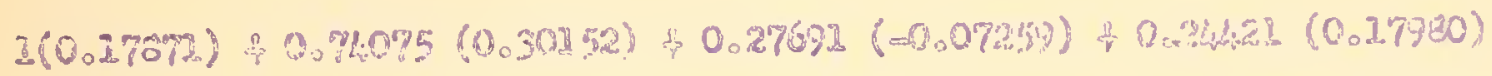

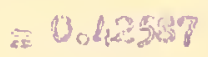

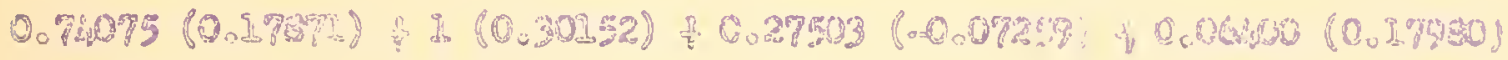

$$
\text { O. } 40.20
$$

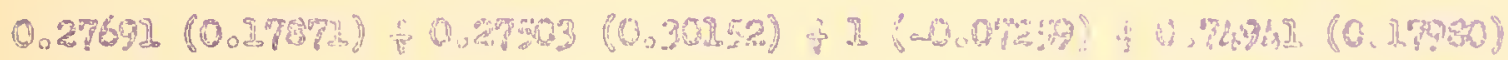

$-0.998,5$

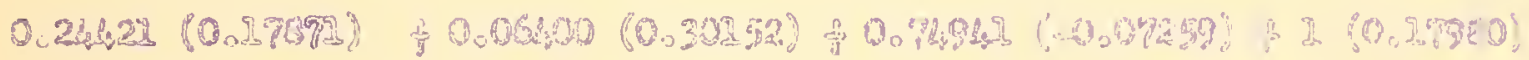
$\therefore 0,35923$

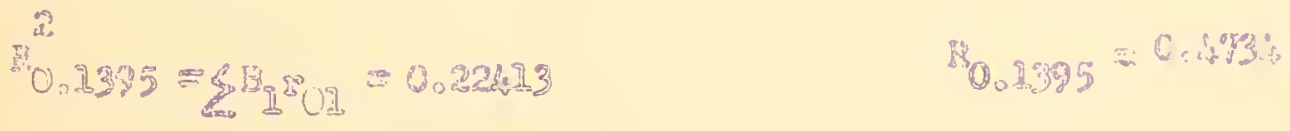

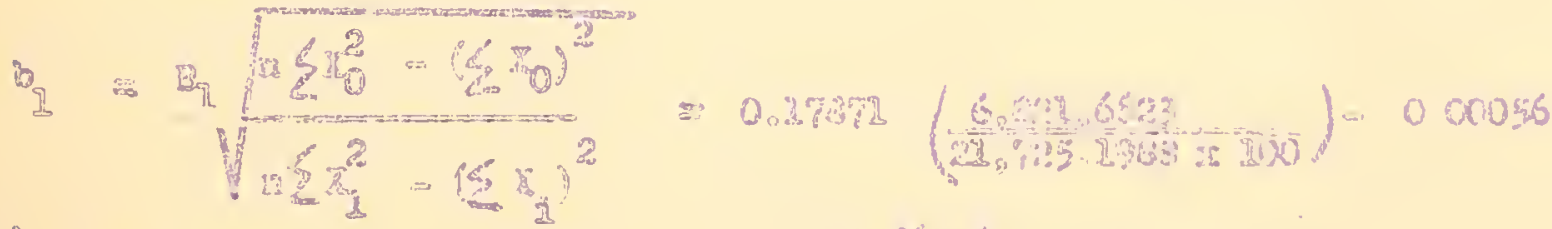

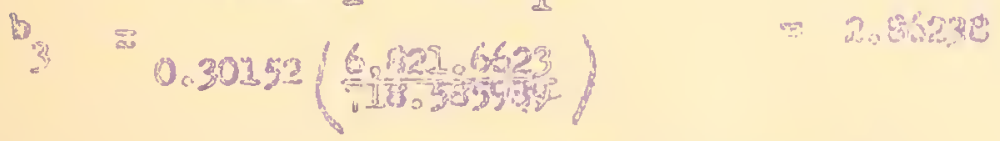

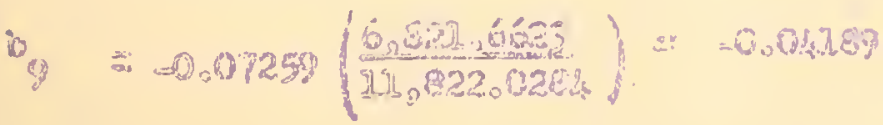

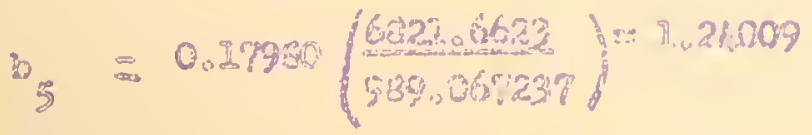

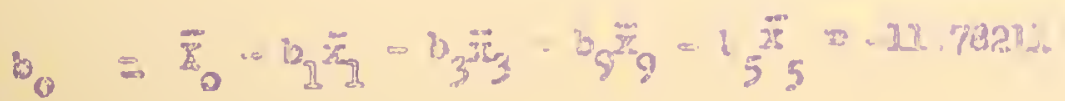




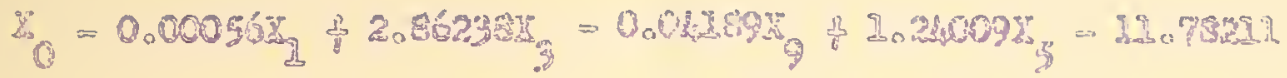

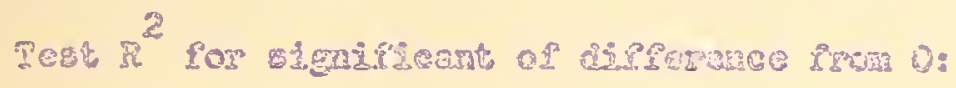

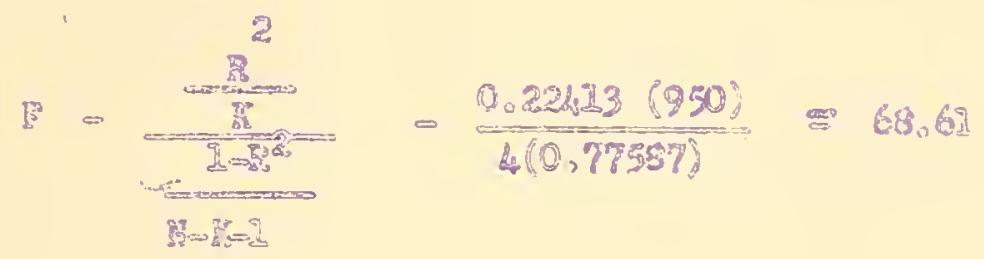

$$
69627298
$$

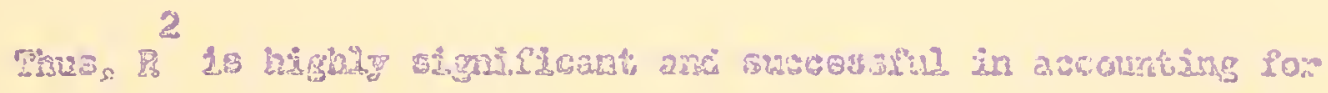

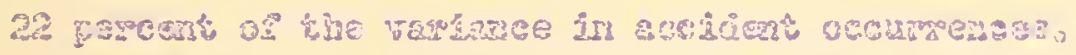



